\title{
$\mathrm{UiO}$ : Det juridiske fakultet
}

\section{Sammensatte arbeidsgiverforhold}

Kandidatnummer: 217

Leveringsfrist: 15.01.2013 kl. 12:00

Antall ord: 33676 


\section{Innholdsfortegnelse}

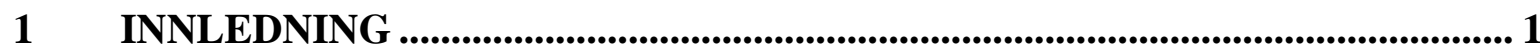

1.1 Introduksjon av emnet ................................................................................ 1

1.2 Problemstilling, sentrale spørsmål ........................................................... 1

1.3 Utgangspunkter videre; begrepsbruk, terminologi og avgrensninger ..................... 2

1.31 Introduksjon av fremstillingens terminologi ........................................... 2

1.32 Avgrensninger .............................................................................. 3

1.4 Rettskildegrunnlag og metodiske bemerkninger ........................................... 4

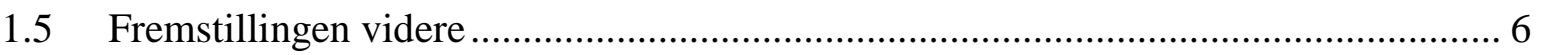

2 HOVEDTREKK OG UTGANGSPUNKTER VED SAMMENSATTE ARBEIDSGIVERFORHOLD ...................................................................... 7

$2.1 \quad$ Utgangspunktet - det bilaterale arbeidsforholdet ......................................... 7

2.11 Arbeidsforholdet mellom arbeidstaker og arbeidsgiver. ............................ 7

2.12 Primærarbeidsgiver - ansvarssubjektet etter loven ............................... 8

2.2 Identifiseringen av primærarbeidsgiver ................................................... 10

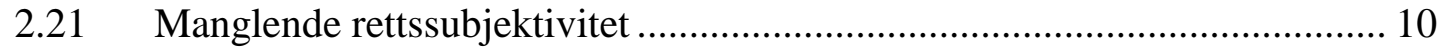

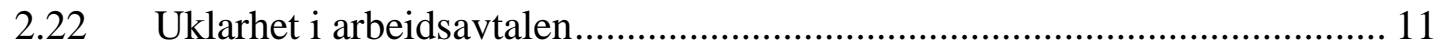

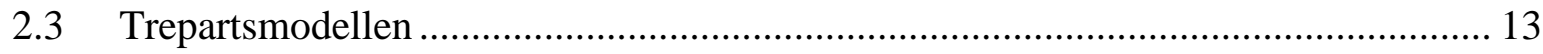

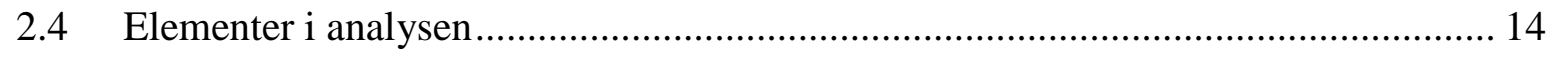

2.41 Former for etableringsgrunnlag ..................................................... 14

2.42 Nærmere om offentligrettslig grunnlag............................................. 15

2.43 Nærmere om privatrettslige grunnlag ............................................... 15 
2.5 Virksomhetsbegrepets betydning for ansvarsplasseringen ................................. 16

3 SAMMENSATTE ARBEIDSGIVERFORHOLD I RELASJON TIL HMS..... 18

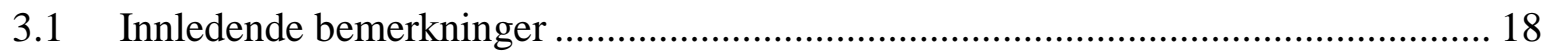

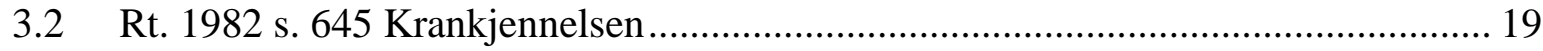

3.21 Avgjørelsens relevans for sammensatte arbeidsgiverforhold.................... 19

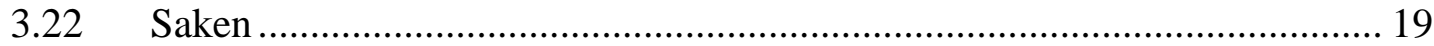

3.23 Analyse og vurdering .................................................................. 19

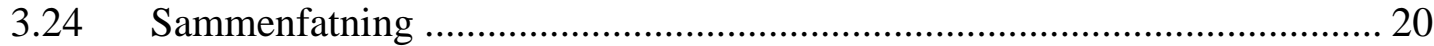

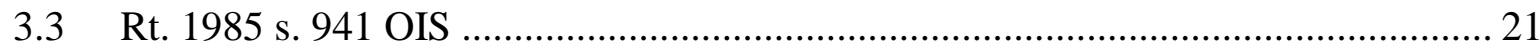

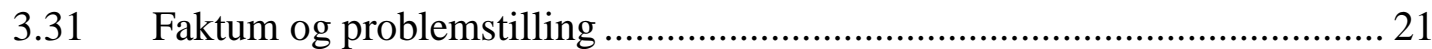

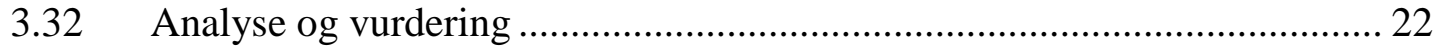

3.4 Rt. 1990 s. 419 Asbest ...................................................................................... 24

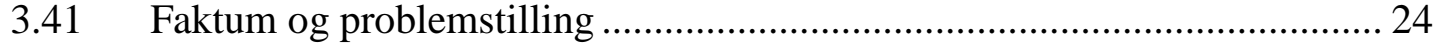

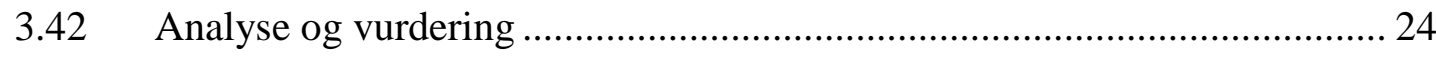

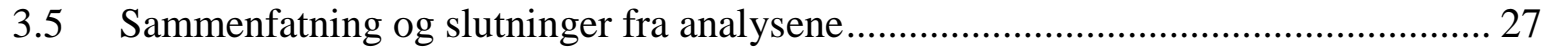

3.6 Plasseringen av ansvar hos virksomhetsleder............................................ 31

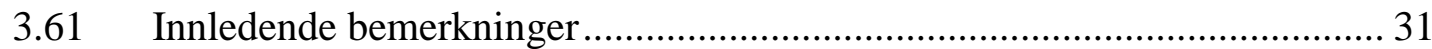

3.62 Adgangen til å holde flere virksomhetsledere ansvarlige samtidig ............. 32

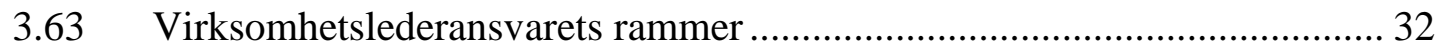

3.64 Selve plasseringen - vurderingen og momentene .................................. 35

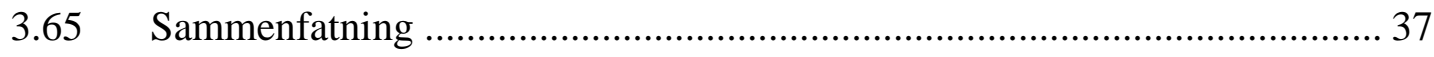

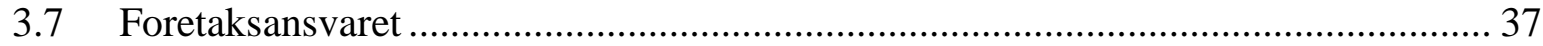


4 SAMMENSATTE ARBEIDSGIVERFORHOLD I RELASJON TIL STILLINGSVERNET ............................................................................................. 39

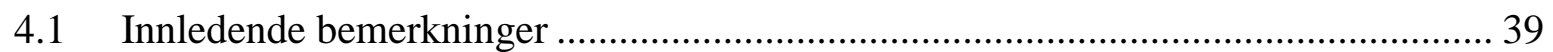

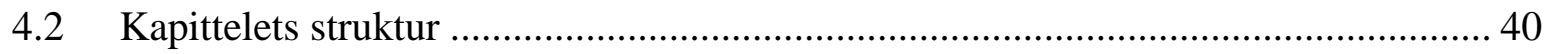

4.3 Doble arbeidsavtaleforhold.................................................................................. 41

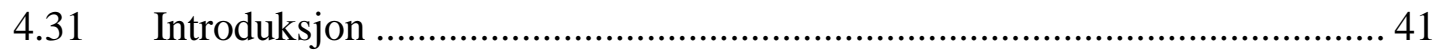

$4.32 \quad$ ExLog-dommen.................................................................................. 41

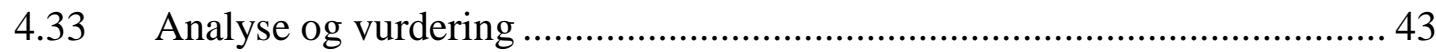

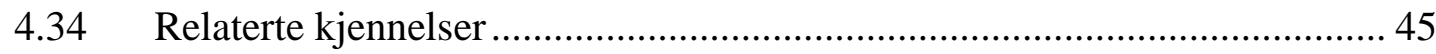

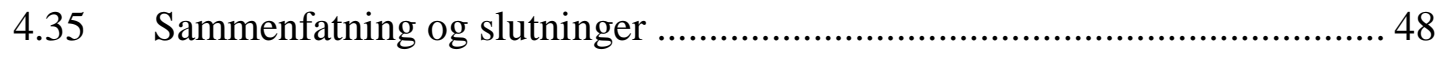

4.4 Rt. 2012 s. 983 Stena Drilling ......................................................................... 51

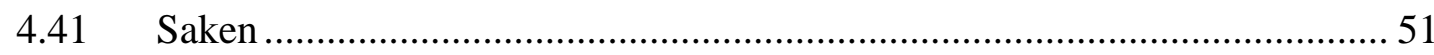

4.42 Analyse og vurdering .......................................................................... 52

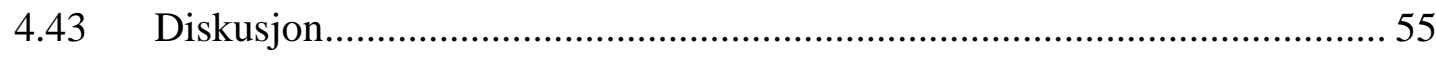

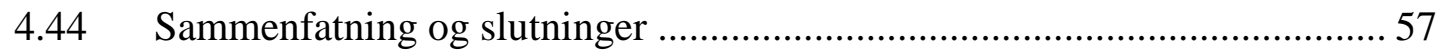

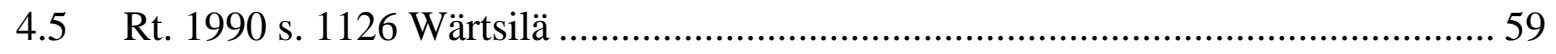

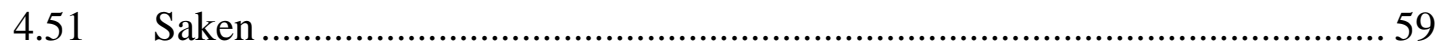

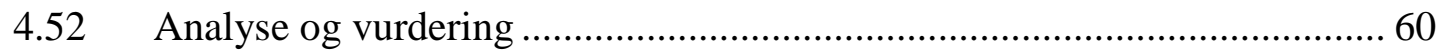

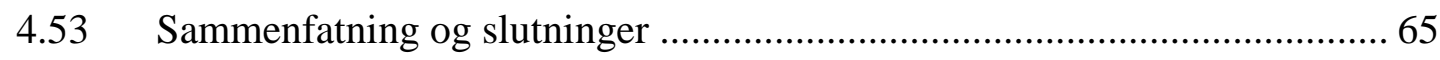

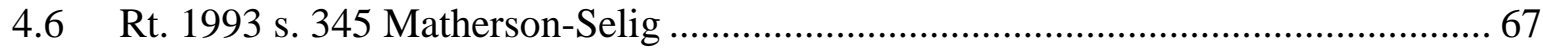

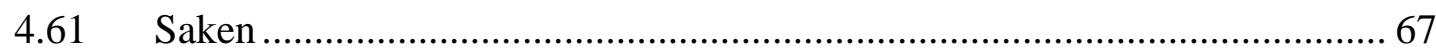

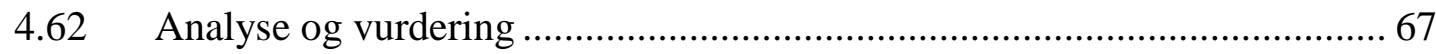

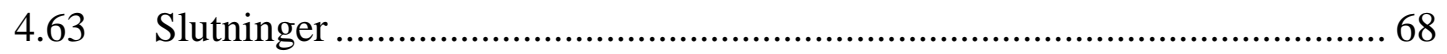




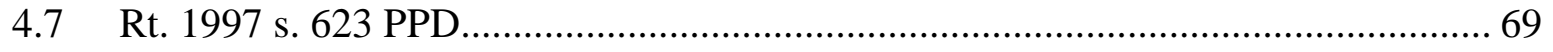

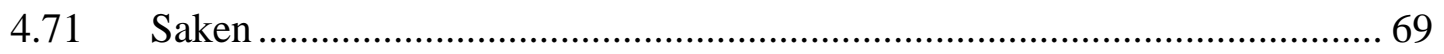

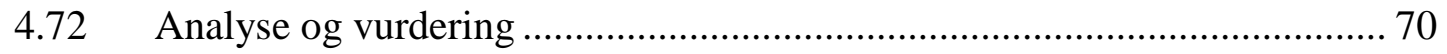

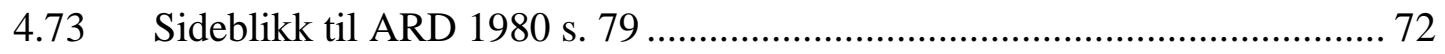

$4.74 \quad$ Sammenfatning og slutninger ............................................................... 74

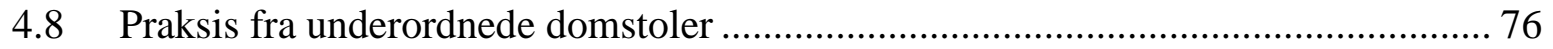

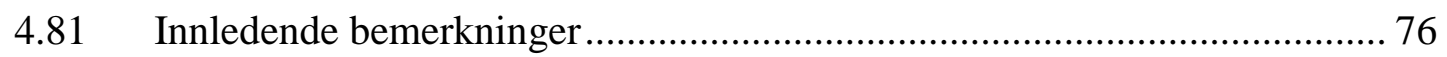

4.82 Flere arbeidsgivere - sammenblanding og delte arbeidsgiverfunksjoner .... 76

4.83 Praksis med vekt på et utvidet virksomhetsbegrep ...................................... 79

4.84 Arbeidsgiverforhold som ikke var sammensatt........................................... 84

4.9 Hovedlinjer om sammensatte arbeidsgiverforhold og stillingsvernet ....................... 85

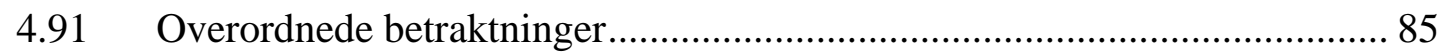

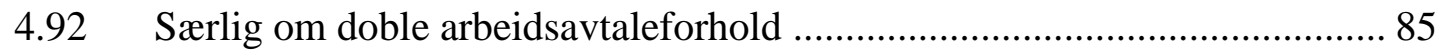

4.93 Særlig om lovbasert delte arbeidsgiverposisjoner...................................... 88

4.94 Nærmere om posisjonen som sekundærarbeidsgiver .................................... 90

5 KONKLUSJONER.................................................................................................. 91

6 SIDEBLIKK TIL SELSKAPSRETTENS GJENNOMSKJERINGS- OG IDENTIFIKASJONSREGLER.....................................................................................98

7 AVSLUTTENDE BEMERKNINGER .......................................................... 100

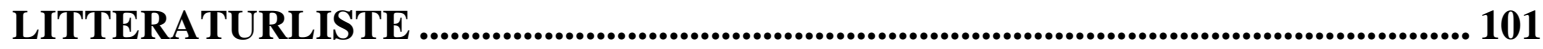




\section{Innledning}

\subsection{Introduksjon av emnet}

Arbeidsforholdet er typisk sett et bilateralt forhold; det er et gjensidig forpliktende forhold mellom to parter, arbeidstaker og arbeidsgiver. Rettsforholdet mellom partene beror i utgangspunktet på en kontrakt, arbeidsavtalen. Ved siden av de privatrettslige plikter og rettigheter som følger med arbeidsforholdet, følger dessuten offentligrettslige forpliktelser for den ene eller andre av partene. Reglene om arbeidsmiljø og vernesamarbeid i arbeidsmiljøloven $^{1}$ er et typisk eksempel på dette.

Selv om arbeidsforholdet i utgangspunktet er tosidig, har vi eksempler på det som kan betegnes som «sammensatte arbeidsgiverforhold». ${ }^{2}$ I dette ligger det at flere enn én part har rettighets- og pliktposisjoner som arbeidsgiver i ett og samme arbeidsforhold. Slike partskonstellasjoner kan forekomme både i kontraktsmessig henseende, om rettigheter og plikter på bakgrunn av avtale, og etter offentligrettslige regler. Lovgivningen regulerer ikke direkte når slike sammensatte arbeidsforhold kan oppstå, og bare i liten grad hvilke rettsvirkninger det har for de involverte. Dette er problemstillinger som først og fremst er utviklet og behandlet i rettspraksis. Emnet for denne avhandlingen er nettopp slike problemstillinger.

\subsection{Problemstilling, sentrale spфrsmål}

Formålet med avhandlingen er å unders $\varnothing$ ke de rettsfakta som etablerer sammensatte arbeidsgiverforhold, og betydningen av at arbeidsgiverforholdet er sammensatt med hensyn til plasseringen av ansvar.

På rettsfaktasiden oppstår spørsmål om når og hvordan et sammensatt arbeidsgiverforhold kan oppstå. Spørsmålet på rettsfølgesiden gjelder hvilke konsekvenser et slikt sammensatt arbeidsgiverforhold har for partenes rettigheter og plikter. Begge spørsmål omfatter hvilket rettsgrunnlag sammensatte arbeidsgiverforhold kan bygge på. Som nevnt kan slike forhold tenkes etablert etter privatrettslige regler og etter offentligrettslige regler som knytter seg til partene i arbeidsforholdet.

$1 \quad$ Lov 17. juni $2005 \mathrm{nr} 62 \mathrm{om}$ arbeidsmiljø, arbeidstid og stillingsvern mv. (aml.).

2 Begrepet «sammensatte arbeidsgiverforhold» ble benyttet av Konsernutvalget i forbindelse med beskrivelsen av faktum i Rt. 1989 s. 231 ExLog, jf. NOU 1996: 6 punkt 3.12. 
Spørsmålene i avhandlingen knytter seg særlig til arbeidsgiverbegrepet i aml. § 1-8(2). I sammenheng med dette er det grunn til også å trekke inn bestemmelsene om arbeidsgiveransvar og foretaksansvar i lovens $\S 19-1$ og 19-3.

\subsection{Utgangspunkter videre; begrepsbruk, terminologi og avgrensninger}

\subsection{Introduksjon av fremstillingens terminologi}

Det alminnelige arbeidsgiverbegrepet $\mathrm{i}$ arbeidsmiljøloven omfatter etter lovens $\S 1-8(2)$ «enhver som har ansatt arbeidstaker for å utføre arbeid i sin tjeneste». Begrepet arbeidstaker er tilsvarende definert som «enhver som utfører arbeid i annens tjeneste», jf. $§ 1-8(1)$. I legaldefinisjonene ligger det en alminnelig forutsetning om at det foreligger et kontraktsmessig gjensidighetsforhold mellom de to partene som utgjør grunnlaget for arbeidsforholdet. ${ }^{3}$ Arbeidsgiverdefinisjonen er likevel så generelt utformet at den også kan omfatte tilfeller der det opptrer to, eller eventuelt flere, aktører som har rettigheter eller plikter på arbeidsgiversiden.

I tilfeller med flere aktører på arbeidsgiversiden er imidlertid lovens terminologi utilstrekkelig for en presis beskrivelse og vurdering av problemstillingene. I det følgende vil jeg derfor bruke begreper som skiller mellom de ulike aktørene. Primararbeidsgiveren (P) er part i arbeidsavtalen, ${ }^{4}$ eventuelt part i det som kalles «hovedarbeidsavtalen» (HAA) der den sammensatte arbeidsgiverstillingen bygger på arbeidstakers kontraktsforhold til flere aktører. Den andre aktøren på arbeidsgiversiden betegner jeg som sekundararbeidsgiveren (S). Forholdene som de to aktørene har til arbeidstaker, omtaler jeg som henholdsvis "primærarbeidsforholdet" og "sekundærarbeidsforholdet". Forholdet aktørene imellom kaller jeg "forretningsforholdet" (FF). Alle aktørene, og forholdene mellom dem, omfattes imidlertid av det samme arbeidsforholdet i vid forstand.

3 Det kan tenkes unntak. Begrepene omfatter «arbeid i tjeneste». Det kan derfor tenkes at en person vil bli ansett som arbeidstaker på grunnlag av at det faktisk utføres arbeid, selv om det ikke er noen avtale i ordinær forstand mellom partene. Dette er imidlertid så spesielt at jeg lar det ligge.

4 Begrepet «primærarbeidsgiver» er hentet fra forarbeidene til arbeidsmiljøloven, jf. NOU 2004: 5 s. 145 og Ot.prp. nr. 49 (2004-2005) s. 76 i.f. Se også NOU 1999: 34 pkt. 7.3.2.1. 
De sammensatte situasjonene kan skisseres grafisk på en enkel måte, slik:

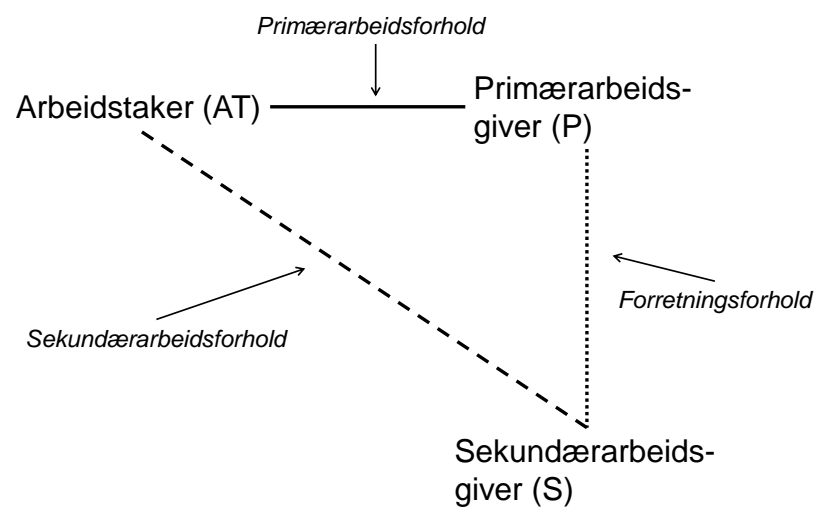

\subsection{Avgrensninger}

Arbeidsmiljøloven $\S 2$-2 retter seg mot situasjoner der andre enn arbeidsgivers egne arbeidstakere utfører arbeidsoppgaver i tilknytning til arbeidsgivers virksomhet. Etter bestemmelsen plikter arbeidsgiver å innrette egen virksomhet, samt å samarbeide med andre arbeidsgivere, slik at også deres arbeidstakeres rett til et fullt forsvarlig arbeidsmiljø ivaretas. Bestemmelsen hjemler særskilte offentligrettslige forpliktelser som påligger den enkelte arbeidsgiver direkte. Følgelig er det ikke «sammensatte arbeidsgiverforhold» slik begrepet er anvendt i denne fremstillingen. Tilfeller som reguleres av $\$ 2-2$, holder jeg derfor utenfor i det følgende.

Ved ut- og innleie av arbeidskraft, som etter aml. $\S$ 14-12 og 14-13, er arbeidsforholdet i utgangspunktet et topartsforhold mellom utleievirksomheten og den arbeidstakeren som leies ut. I slike forhold kan det likevel bli spørsmål om innleievirksomheten kan få en arbeidsgiverposisjon for den arbeidstakeren som er leid ut. Aml. § 14-12(3) kan gi grunnlag for dette. I slike tilfeller vil imidlertid det typiske være at arbeidsgiverposisjonen går over fra utleievirksomheten til innleieren. Ut over dette reguleres innleiesituasjonene av $\S 2-2$. Dermed blir det ikke tale om et sammensatt arbeidsgiverforhold slik jeg anvender begrepet.

Det samme gjelder ved overføring av virksomhet etter reglene i aml. kapittel $16 .^{5}$ Ved virksomhetsoverdragelse er hovedregelen at arbeidsgiverposisjonen overføres fra over-

5 Reservasjon for spesielle tilfeller av solidaransvar. 
drager til erverver. Slike spørsmål faller derfor også utenfor rammen for denne avhandlingen.

Jeg avgrenser også mot tilsvarende bestemmelser og lignende problemstillinger etter andre lover, herunder sjømannsloven av 30. mai 1975 nr. 18 og lov 4. mars 1983 nr. 3 om statens tjenestemenn m.m. I fremstillingen holder jeg meg til arbeidsmiljøloven.

\subsection{Rettskildegrunnlag og metodiske bemerkninger}

Det vi kan kalle læren om sammensatte arbeidsgiverforhold, er som nevnt under punkt 1.1 først og fremst utviklet i rettspraksis. Høyesterett har i flere sammenhenger lagt til grunn at arbeidsmiljølovens regler ikke er til hinder for at flere rettssubjekter kan ha et arbeidsgiveransvar overfor samme arbeidstaker. Dommen i Rt. 1990 s. 1126 Wärtsilä er et klart eksempel på dette (s. 1132).

Problemstillingene er i utgangspunktet ikke direkte regulert i lovgivningen. Konsernutvalget vurderte en lovregulering på dette punkt i sin innstilling i NOU 1996: 6. Utvalgets utredning munnet ut $\mathrm{i}$ et flertallsforslag om å kodifisere et utvidet arbeidsgiverbegrep. Arbeidstakernes rettsstilling skulle avgjøres ut fra «de reelle eierforhold, den reelle beslutningsstruktur og de økonomiske interesser knyttet til denne», ${ }^{6}$ i motsetning til den formelle foretaksstrukturen og arbeidsavtalens angivelse av arbeidsgiveren. Det utvidede arbeidsgiverbegrepet omfattet arbeidsgiver etter arbeidsavtalen samt «ethvert annet foretak som [kunne] utøve bestemmende innflytelse over [denne]», jf. s. 10. I konsernforhold ville dette innebære at morselskapet kunne ha arbeidsgiveransvar for de ansatte i datterselskapene. Forslaget møtte stor motstand i høringsrunden og ble ikke fulgt opp. Et mindre omfattende utkast til endringer ble sendt på høring av departementet i 1998. ${ }^{7}$ Det møtte også motstand og ble heller ikke fulgt opp med forslag om nye lovregler. I forarbeidene til arbeidsmiljøloven av 2005 var problemstillingene på ny gjenstand for behandling. Først i Arbeidslivslovutvalgets utredning, ${ }^{8}$ så i lovforslaget fra departementet. ${ }^{9}$ Ved komitébehandlingen i Stortinget delte komiteen seg i et flertall og et mindretall, hvor flertallet

6 Jf. NOU 1996: 6 s. 10.

7 Se Kommunal- og regionaldepartementet, Oppfølgning av Konsernutvalgets innstilling $m v$ (1998).

$8 \quad$ Jf. NOU 2004: 5 s. 159 flg.

$9 \quad$ Jf. Ot.prp. nr. 49 (2004-2005) s. 76 flg. 
gikk inn for et lovfestet utvidet arbeidsgiverbegrep. ${ }^{10}$ Flertallet i Odelstinget gikk derimot inn for å videreføre arbeidsgiverbegrepet fra dagjeldende lov, ${ }^{11}$ og siste ord var dermed sagt i den omgang. Med unntak av enkelte språklige endringer er arbeidsgiverbegrepet i dag det samme som ble introdusert med arbeidsmiljøloven av 1977. ${ }^{12}$

Store deler av rettspraksis om sammensatte arbeidsgiverforhold knytter seg til arbeidsmiljøloven av 1977. Særlig gjelder dette høyesterettspraksis om disse problemstillingene. Selv om 1977-loven er avløst av arbeidsmiljøloven av 2005, er denne rettspraksis fortsatt relevant. Bakgrunnen for dette er at de lovreglene som fremstillingen viser til, $\mathrm{i}$ all hovedsak er videreført. ${ }^{13}$ I tillegg anså departementet rettspraksisen om sammensatte arbeidsgiverforhold for å være «god og treffende», og brukte dette som en del av begrunnelsen mot å lovfeste et utvidet arbeidsgiverbegrep. ${ }^{14}$

Ved analysen og drøftelsen av de ulike problemstillingene om sammensatte arbeidsgiverforhold er Høyesteretts rettspraksis den sentrale rettskildefaktoren. Det følger av alminnelig juridisk metode, og det er en slik tilnærming jeg bygger på i denne avhandlingen. Hvilken vekt rettsanvenderen kan legge på rettspraksis fra underordnede domstoler - avgjørelser fra tingrettene og lagmannsrettene - har vært diskutert i stort omfang i juridisk teori. ${ }^{15}$ Det er imidlertid ikke grunn til å gå nærmere inn på denne diskusjonen her. I den videre fremstillingen vil jeg bruke slik underrettspraksis i en viss utstrekning, i utgangspunktet med tanke på å illustrere og presentere relevante problemstillinger og mulige løsninger.

Rettspraksis om sammensatte arbeidsgiverforhold kan grovt sett sies å behandle problemstillinger i to ulike relasjoner. Den ene gjelder arbeidsmiljøbestemmelsene - eller arbeidsgivers ansvar for helse, miljø og sikkerhet (HMS), særlig i forbindelse med straffansvaret. Den andre gjelder avgjørelser om privatrettslige forhold. Denne relasjonen

Jf. Innst. O. nr. 100 (2004-2005) punkt 6.2.

Jf. Forh. O. nr. 52 (2004-2005) s. 851 flg.

Lov 4. februar 1977 nr. 4 om arbeidervern og arbeidsmiljø m.v. (aml. (1977)), jf. Ot.prp. nr. 3 (1975-76) s. 102.

Se Ot.prp. nr. 49 (2004-2005) s. 302 og 343 flg.

Jf. Ot.prp. nr. 49 (2004-2005) s. 76.

Se Fleischer, Rettskilder og juridisk metode (1998) s. 269 flg., Eckhoff m.fl., Rettskildelaere (2001) s. 162 og Andenæs, Rettskildelcere (1997) s. 44 flg. 
domineres av saker om stillingsvern, men det er også noe rettspraksis om vederlagsspørsmål og lønnsansvar. Dette er et skille jeg vil benytte i det følgende.

\subsection{Fremstillingen videre}

Oppgaven består av kapitler (nivå 1); som er inndelt i avsnitt (nivå 2); der de fleste inneholder flere punkter (nivå 3).

Under kapittel 2 behandler jeg arbeidsgiverbegrepet mer generelt, herunder legaldefinisjonen i arbeidsmiljøloven og forutsetningene for å være arbeidsgiver. I tillegg gis et mer detaljert innblikk i trepartsmodellen.

Kapitlene 3 og 4 omhandler sammensatte arbeidsgiverforhold i ulike relasjoner; henholdsvis arbeidsgivers ansvar for overholdelsen av HMS-bestemmelsene og stillingsvernsreglene. I disse kapitlene analyseres ulike rettsavgjørelser med sikte på å utlede noen hovedlinjer om sammensatte arbeidsgiverforhold

Under kapittel 5 sammenfatter jeg slutningene som er utledet om sammensatte arbeidsgiverforhold under kapittel 3 og 4.

Kapittel 6 inneholder et sideblikk til selskapsrettens gjennomskjærings- og identifikasjonsregler. I dette kapittelet fors $\varnothing$ ker jeg å se sammensatte arbeidsgiverforhold fra et selskapsrettslig perspektiv.

Under kapittel 7 er det inntatt en avslutning, før litteraturlisten følger under kapittel 8. 


\section{Hovedtrekk og utgangspunkter ved sammensatte arbeidsgiverforhold}

\subsection{Utgangspunktet - det bilaterale arbeidsforholdet}

\subsection{Arbeidsforholdet mellom arbeidstaker og arbeidsgiver.}

Ved å inngå et arbeidsforhold forplikter arbeidstaker seg til å utføre arbeid i en «annens tjeneste», jf. aml. § 1-8(1). Arbeidstakerposisjonen innebærer en plikt for vedkommende til å underordne seg i arbeidsforholdet, blant annet ved å følge de instrukser som blir gitt i tjenesteutførelsen. Arbeidsgiveren er den som har ansatt arbeidstaker «for å utføre arbeid i sin tjeneste», jf. § 1-8(2). Arbeidsgiverdefinisjonen speiler arbeidstakerdefinisjonen, og ifølge forarbeidene var det naturlig å identifisere arbeidsgiver ut fra om motparten falt inn under arbeidstakerbegrepet. ${ }^{16}$ Posisjonen som arbeidsgiver gir blant annet vedkommende krav på arbeidstakers tjenester mot vederlag.

I kraft av styringsretten har arbeidsgiver kompetanse til å fastsette arbeidets nærmere innhold. Styringsretten må imidlertid utøves innen visse rammer. I den individuelle arbeidsavtalen kan partene fastsette rammene og det nærmere innholdet $i$ arbeidsforholdet mellom dem, og dermed regulere arbeidsgivers kompetanse. Arbeidsavtalen kan være skriftlig, normalt i form av en ansettelseskontrakt, eller muntlig. Etter arbeidsmiljøloven er arbeidsgiver forpliktet til å sørge for at en skriftlig arbeidsavtale blir inngått, jf. aml. § 14-5, men skriftlighet er ikke et gyldighetskrav - en muntlig avtale er like fullt bindende mellom partene. ${ }^{17}$

Maktbalansen mellom partene er imidlertid ofte skjev i favør av arbeidsgiver, og arbeidsavtalen suppleres derfor av andre instrumenter som lovgivning, tariffavtale og ulovfestede allmenne saklighetsnormer. ${ }^{18}$ I den arbeidsrettslige lovgivningen har arbeidsmiljøloven en sentral plass. Loven kommer til anvendelse på «virksomhet som sysselsetter arbeidstaker», jf. § 2-1. Virksomhetsbegrepet omtales nærmere under avsnitt 2.5.

Jf. Ot.prp. nr. 3 (1975-76) s. 102.

$17 \quad$ Se Storeng m.fl., Arbeidslivets spilleregler (2011) s. 46 flg. og 74.

$18 \quad$ Se Storeng m.fl. (2011) s. 46 flg. 


\subsection{Primærarbeidsgiver - ansvarssubjektet etter loven}

Ifølge aml. § 2-1 er arbeidsgiver ansvarlig for at «bestemmelsene gitt i eller i medhold av» loven blir overholdt. Bestemmelsen viderefører aml. (1977) § 14(1). Arbeidsgiver har dermed hovedansvaret for at arbeidsmiljøbestemmelsene og stillingsvernsreglene blir overholdt. Posisjonen som arbeidsgiver kan følgelig innebære et stort ansvar, og det er derfor naturlig med en kort gjennomgang av arbeidsgiverbegrepet slik det følger av lovens bestemmelser.

Arbeidsgiver kan være en fysisk person som arbeidstakeren utfører tjenester for, eller det kan være en juridisk person, et foretak. Ettersom et foretak i seg selv ikke kan utøve arbeidsgiverfunksjoner, gjøres dette av foretakets organer. Eksempelvis vil daglig leder kunne opptre på vegne av foretaket ved ansettelsen. Partsforholdet i arbeidsavtalen endres imidlertid ikke ved en slik representasjon. Arbeidstakeren vil fortsatt være ansatt av og i foretaket.

Ansvarssubjektet i relasjon til ansvar av privatrettslig karakter vil være arbeidsgiver etter $\S 1-8(2)(1)$, altså vedkommende person eller foretak. Arbeidstaker forholder seg følgelig til denne med krav om arbeidsvederlag eller krav som springer ut av at arbeidsmiljølovens bestemmelser om stillingsvern etter lovens kapitler 14 til 16 ikke er overholdt. Når det gjelder arbeidsmiljøbestemmelsene, er bildet imidlertid mer sammensatt. Som et utgangspunkt vil det også i denne sammenheng være arbeidsgiver etter §1-8(2)(1) som er ansvarssubjektet. Behovet for å identifisere arbeidsgiver er dermed like sterkt i relasjon til arbeidsmiljøbestemmelsene som etter stillingsvernsbestemmelsene. Ansvaret for å overholde arbeidsmiljøbestemmelsene er imidlertid primært av offentligrettslig karakter. Bestemmelsene håndheves normalt av Arbeidstilsynet, jf. § 18-1. Dersom arbeidsmiljøbestemmelsene er overtrådt og arbeidsgiver ikke har ivaretatt sitt ansvar for arbeidstakernes helse, miljø og sikkerhet (HMS-ansvaret), vil det normalt bli reagert med administrative reaksjoner, eventuelt også straffesanksjoner, jf. § 19-1. Bestemmelsene om oppsigelsesvern i lovens kapittel 14 og 15 er uttrykkelig unntatt fra slike reaksjoner, jf. § 19-1(4), og det samme må antas å gjelde for bestemmelsene om arbeidstakeres rettigheter ved virksomhetsoverdragelse i kapittel $16 .{ }^{19}$

19 Forarbeidenes vektlegging av at «stillingsvern» skal forstås vidt, taler for denne forståelsen, jf. Ot.prp. nr. 49 (2004-2005) s. 294. 
Etter aml. § 19-1 kan det offentlige reagere med straff og/eller bøter overfor «innehaver av virksomhet, arbeidsgiver eller den som i arbeidsgivers sted leder virksomheten». Sanksjoner etter $\S 19$-1 overfor «innehaver av virksomhet» er tilsynelatende ikke behandlet i rettspraksis, og vil følgelig ikke bli nærmere behandlet i denne fremstillingen. Med dette står man igjen med de samme ansvarssubjekter som følger av arbeidsgiverdefinisjonen i aml. § 1-8 (2) - arbeidsgiver og den som leder virksomheten i arbeidsgivers sted. Straffansvar etter § 19-1 forutsetter en «forsettlig eller uaktsom overtredelse». På grunn av skyldkravet hjemler bestemmelsen kun sanksjoner mot fysiske personer. Selv om «arbeidsgiver» viser til fysiske personer i den $\emptyset$ verste ledelsen, eksempelvis styret $\mathrm{i}$ aksjeselskap, ${ }^{20}$ blir bestemmelsen normalt anvendt på «den som i arbeidsgivers sted leder virksomheten», eller virksomhetslederen, jf. § 19-1. Virksomhetslederansvaret innebærer at en arbeidstaker, i egenskap av å være leder av bedriften, holdes ansvarlig som arbeidsgiver. $^{21}$

Ordlyden i $\S 1-8(2)(2)$ og 19-1 åpner for tolkning med hensyn til hvem som er å anse som virksomhetsleder. For det første har virksomhet språklig sett flere betydninger. ${ }^{22}$ For det andre kan den som leder $i$ arbeidsgivers sted enten vise til bedriftens фverste leder, typisk daglig leder eller administrerende direktør, eller til personer med lederfunksjoner i tilknytning til den enkelte overtredelse. Bestemmelsene er videreføringer av aml. (1977) $\S \S 4$ og 85, ${ }^{23}$ som igjen var ment å tilsvare arbeidervernloven (1956) $\S 65 .^{24}$ I forarbeidene til 1977-loven ble det påpekt at denne delen av arbeidsgiverbegrepet kun skulle «ramme den $\emptyset$ verste bedriftsledelsen». ${ }^{25}$ Arbeidsgiveransvaret var altså tiltenkt personer som satt $\mathrm{i}$ bedriftens ledende posisjoner, og skulle ikke bli veltet over på ledere lenger ned i organisasjonen. ${ }^{26}$ Hvordan bestemmelsene er tolket i rettspraksis, vil være gjenstand for nærmere behandling under avsnitt 3.6.

Jf. Ot.prp. nr. 3 (1975-76) s. 102 om tilsvarende bestemmelser i aml. (1977) §§ 4 og 85.

Tilsvarende følger det av $§ 1-8(2)(2)$ at det som i loven er bestemt om arbeidsgiver, «skal gjelde tilsvarende for den som i arbeidsgivers sted leder virksomheten».

Se nærmere om dette under avsnitt 2.5.

Jf. henholdsvis Ot.prp. nr. 49 (2004-2005) s. 302 og 343.

Jf. Ot.prp. nr. 3 (1975-76) s. 102.

Se Ot.prp. nr. 3 (1975-76) s. 102.

Se i denne sammenheng diskusjonene i forarbeidene omkring målet om å unngå at foretaket kunne gjøre ansatte til syndebukker, jf. Ot.prp. nr. 3 (1975-76) s. 213. 
Juridiske personer er ikke immune mot straffansvar, til tross for at aml. § 19-1 forutsetter

subjektiv skyld. Foretaksansvaret er regulert i straffeloven ${ }^{27} \S \S 48 \mathrm{a}$ og 48b, jf. aml. § 19-3. Foretaket kan straffes dersom en som har handlet «på vegne av foretaket», har overtrådt et straffebud, uavhengig av om vedkommende kan straffes, jf. § 48a. Det er altså et objektivt ansvar for foretaket som sådan. Aml. $§ 19-3$ er en videreføring av aml. (1977) $\S 87,{ }^{28}$ slik denne bestemmelsen lød etter revisjonen ved lov 27. november $1992 \mathrm{nr}$. 115. Tidligere var foretaksansvaret direkte regulert i arbeidsmiljøloven, jf. $\S 87$ slik den lød før opphevelsen ved lov 20. juli $1991 \mathrm{nr} .66 .^{29}$

Foretaksansvaret er etter sin ordlyd ikke begrenset til et rent arbeidsgiveransvar. Grunnvilkåret for ansvar etter strl. § 48a, jf. § 19-3, er at noen som har handlet «på vegne av» foretaket har overtrådt et straffebud. En som handler på vegne av foretaket, trenger ikke være ansatt der. En kan imidlertid slutte det motsatte, at en ansatt normalt vil handle på vegne av arbeidsgiveren.

\subsection{Identifiseringen av primararbeidsgiver}

\subsection{Manglende rettssubjektivitet}

Den klare hovedregel er som nevnt at arbeidsgiver må være et rettssubjekt. Dersom arbeidsgiver etter arbeidsavtalen ikke er et rettssubjekt, men for eksempel en filial av et norskregistrert utenlandsk selskap (NUF) eller et selskap under stiftelse, ligger arbeidsgivers plikter og rettigheter ikke hos filialen/selskapet under stiftelse. Dersom arbeidsavtalen er inngått med et NUF på arbeidsgiversiden, vil det som et klart utgangspunkt være det utenlandske foretaket som er arbeidsgiver. ${ }^{30}$ Dersom arbeidsgiver er en sammenslutning uten rettssubjektivitet, er man henvist til å identifisere arbeidsgiver ut fra en konkret vurdering. ${ }^{31}$ Dette behandler jeg nærmere under punkt 2.22 .

$27 \quad$ Almindelig borgerlig Straffelov 22. mai 1902 nr. 10 (strl.)

28 Jf. Ot.prp. nr. 49 (2004-2005) s. 344.

$29 \quad$ Før opphevelsen lød bestemmelsen: «Er en overtredelse av bestemmelse eller pålegg, gitt i eller i medhold av denne lov, begått av noen som har handlet på vegne av en juridisk person, ... kan bøtestraff idømmes virksomheten som sådan, selv om ingen kan straffes etter $\S \S 85$ og 86.»

Reiersen m.fl., «NUF-kaoset i norsk rett - et bidrag til oppklaring», Tidsskrift for rettsvitenskap (2010), s. 445.

31 Jf. Rt. 1997 s. 623 PPD (s. 630) med videre henvisning til NOU 1995:17 s. 71. 


\subsection{Uklarhet $\mathrm{i}$ arbeidsavtalen}

Normalt vil arbeidsavtalen angi hvem som er parter i arbeidsforholdet. Arbeidsgiveren er arbeidstakerens motpart, og arbeidet skjer i vedkommende arbeidsgivers tjeneste. Det forekommer imidlertid tilfeller hvor det er uklart hvem som er arbeidsgiver. Dette kan skyldes at arbeidsavtalen ikke sier noe konkret om hvem som er arbeidsgiver, eller at det ikke finnes noen skriftlig avtale å forholde seg til. Spørsmålet er da hvordan man avgjør hvem som er arbeidsgiver.

I Back Stage-avgjørelsen ${ }^{32}$ tok Høyesterett stilling til om et aksjeselskap eller eierne av dette var arbeidsgivere i en restaurantbedrift. Eierne arbeidet i ledelsen av selskapet, og det var ingen skriftlig avtale med arbeidstakerne som klargjorde hvem som var arbeidsgiveren deres. Etter en konkret vurdering kom Høyesterett til at eierne drev restaurantvirksomheten personlig, og at de følgelig var arbeidsgivere. Om arbeidskontraktene uttalte førstvoterende at «det følger av kontraktsforholdets karakter at det normalt vil ha sentral betydning for en arbeidstager å kjenne til hvem som er hans eller hennes arbeidsgiver. Også arbeidsmiljølovens regelverk understreker et krav om klarhet og notoritet ved hvem som er arbeidsgiver. Det må være arbeidsgiverens plikt å sørge for denne avklaring» (s. 957). Videre ble det påpekt at «i tråd med alminnelige avtalerettslige regler» måtte det kreves at arbeidstakerne ble opplyst om at de ble ansatt av selskapet om ikke eierne skulle bli personlig ansvarlige (s. 958). Høyesterett avgjorde saken ut fra en avtalerettslig tilnærming. Eierne, som hadde opptrådt som arbeidsgivere overfor arbeidstakerne, hadde ansvaret for å gjøre det klart at de ikke personlig var arbeidsgivere.

En lignende tilnærming så man i Reksten-avgjørelsen, ${ }^{33}$ hvor Høyesterett konkluderte med at et "manager"-selskap var arbeidsgiver for en maskinsjef i relasjon til utbetalingen av krigsrisikotillegg. Selskapet opptrådte som fullmektig for et rederi og hadde i denne rollen inngått hyrekontrakten med maskinsjefen. For førstvoterende var det avgjørende spørsmålet om det fra selskapets side «på en tilstrekkelig tydelig måte under de eksisterende forhold» var gitt uttrykk for at det ikke var arbeidsgiver, men at det kun opptrådte som fullmektig for rederiet (s. 494). Reksten-avgjørelsen ble dermed også løst på avtalerettslig grunnlag.

33 Rt. 1993 s. 490 Reksten. 
I begge avgjørelser ble arbeidsgiver ansett for å være den som fremstod overfor arbeidstakerne som motpart i arbeidsforholdet. Noe annet var ikke gjort tilstrekkelig klart for arbeidstakerne. Dette betegner jeg som klarhetskravet i relasjon til arbeidsgiverposisjonen. ${ }^{34}$ Etter en avtalemessig tilnærming er det den som objektivt sett har opptrådt som arbeidsgiver ved etableringen av arbeidsforholdet, som er å anse som arbeidsgiver. Dersom andre skal være arbeidsgiver, må dette gjøres tilstrekkelig klart overfor arbeidstaker.

Det fremgår av gjennomgangen at rettspraksis har lagt til grunn en avtalemessig tilncerming for å identifisere arbeidsgiver ved uklarheter i arbeidsavtalen. Et alternativ til denne tilnærmingsmetoden er en funksjonell tilnarming, som vil si at man legger vekt på hvem som utøver arbeidsgiverfunksjoner, en utøvelse som er typisk for arbeidsgiverposisjonen. Denne tilnærmingen er i utgangspunktet av størst relevans når man allerede har klarlagt hvem som er primærarbeidsgiver, og undersøker hvorvidt arbeidsforholdet har sekundærarbeidsgivere. Senere i fremstillingen kommer jeg nærmere tilbake til hvordan en funksjonell tilnærming er blitt lagt til grunn ved vurderingen av om en tredjepart er sekundærarbeidsgiver, se særlig under kapittel 5.

Se også Jakhelln, «Arbeidstakeres rettigheter mot morselskap», MarIus Bind 310 (2004), s. 94. Imidlertid anfører Jakhelln at Høyesterett i Reksten-saken la til grunn en funksjonell tilnærming, og ikke en avtalerettslig. Standpunktet begrunnes med at inngåelsen av arbeidsavtaler er en del av arbeidsgivers styringsrett, og følgelig et ledd i utøvelsen av arbeidsgiverfunksjonene. 


\subsection{Trepartsmodellen}

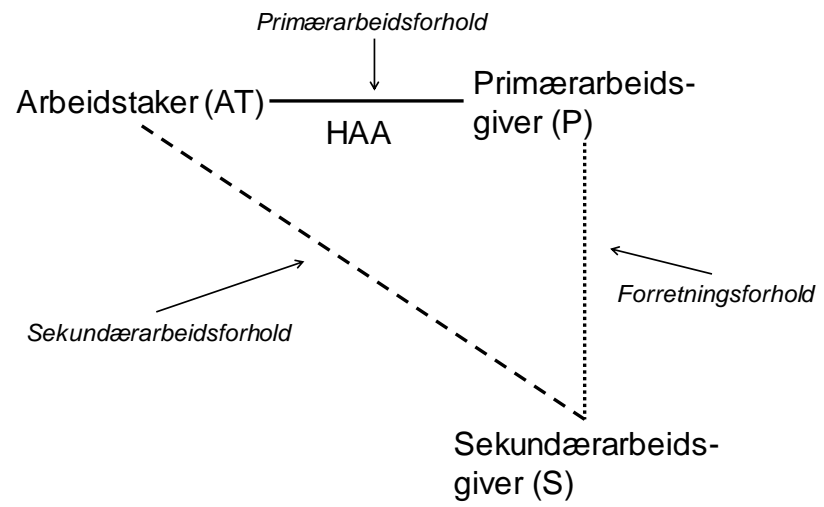

Sammensatte arbeidsforhold kan i det grunnleggende sees som en relasjon mellom tre rettssubjekter - AT, P og S. Alle har en tilknytning til hver av de andre, samtidig som de hører til samme arbeidsforhold $i$ vid forstand.

Relasjonen mellom P og AT er "primararbeidsforholdet". Rettsforholdet bygger på hovedarbeidsavtalen (HAA), som i enkelte sammenhenger utgjør grunnlaget for det sammensatte arbeidsgiverforholdet.

"Forretningsforholdet" mellom S og P vil normalt bygge på enten kontrakt eller eierskap. Forhold som bygger på eierskap, vil ofte kunne kategoriseres i velkjente typer av selskapsgrupperinger som fellesforetak eller konserner. ${ }^{35}$ Typen selskapsgruppering kan ha betydning for vurderingen av de ulike arbeidsforholdene. ${ }^{36}$

"Sekundararbeidsforholdet" mellom AT og S kan bygge på kontrakt, men dette er ikke en nødvendig forutsetning. Er det tale om offentligrettslige regler, kan samtidige plikter for flere arbeidsgiveraktører ha grunnlag i slike bestemmelser. hen til bestemmelsene i aksje- og allmennaksjeselskapsloven $\S \S 1-3$ og 1-4, statsforetaksloven $\S 2$ og i selskapsloven $\S 1-2$. mellom selskaper i et konsernforhold [ikke kunne] få anvendelse ved et interkommunalt samarbeidsforetak» (s. 632). 


\subsection{Elementer $i$ analysen}

\subsection{Former for etableringsgrunnlag}

Som et utgangspunkt kan det skilles mellom sammensatte arbeidsgiverforhold som etableres på offentligrettslig og på privatrettslig grunnlag. Eksempler på forhold som etableres på offentligrettslig grunnlag, har vi særlig når det gjelder arbeidsgivers HMSansvar. Manglende overholdelse av arbeidsmiljøbestemmelsene vil som nevnt under punkt 2.12 kunne resultere i straffesanksjoner, og legalitetsprinsippet i norsk rett forutsetter dermed at det foreligger tilstrekkelig lovgrunnlag for ansvar. Eksempler på forhold som anses etablert på privatrettslig grunnlag, har vi typisk når det gjelder stillingsvernsbestemmelsene. Rettigheter og plikter etter disse bestemmelsene ivaretas av partene $\mathrm{i}$ arbeidsforholdet.

Når et sammensatt arbeidsgiverforhold anses etablert på offentligrettslig grunnlag, vil forbindelsen i "sekundærarbeidsforholdet" mellom sekundærarbeidsgiver og arbeidstaker ofte være indirekte. Med en indirekte forbindelse mener jeg at det ikke ligger noen avtale til grunn for forbindelsen som gir grunnlag for et direkte rettsforhold. I slike situasjoner anses en utenforstående tredjeperson å ha forbindelser til partene i arbeidsforholdet som innebærer at vedkommende må anses som sekundærarbeidsgiver. Forholdet kan kalles en lovbasert delt arbeidsgiverposisjon. Typiske eksempler på dette er der hvor en utenforstående tredjeperson i overensstemmelse med primærarbeidsgiver utøver sentrale arbeidsgiverfunksjoner overfor arbeidstaker. Når dette ikke skjer i overensstemmelse med primærarbeidsgiver, vil det være mer nærliggende å anse forholdet som et selvstendig arbeidsforhold mellom arbeidstaker og tredjeperson.

Sammensatte arbeidsgiverforhold som etableres på privatrettslig grunnlag, kan grovt sett inndeles i to kategorier. Den første omfatter tilfellene hvor arbeidstakers arbeidsforhold med primærarbeidsgiver og sekundærarbeidsgiver følger direkte av ansettelseskontrakten, ved at denne gir begge disse arbeidsgivere rettigheter og forpliktelser overfor arbeidstaker. Det sammensatte arbeidsgiverforholdet bygger da på den direkte forbindelsen mellom arbeidstaker og sekundærarbeidsgiver, og kan betegnes doble arbeidsavtaleforhold, på bakgrunn av at arbeidsavtalen gir arbeidstaker rettigheter og plikter overfor to arbeidsgiveraktører. Den andre kategorien omfatter tilfeller der arbeidsavtalen mellom primærarbeidsgiver og arbeidstaker i seg selv ikke gir grunnlag for å konstatere at et sammensatt arbeidsgiverforhold er oppstått. I slike situasjoner må det vurderes om andre forhold, som "forretningsforholdet" og forholdet mellom tredjeperson og arbeidstaker, gir grunnlag for å holde tredjeperson ansvarlig som sekundærarbeidsgiver. Disse forholdene bygger dermed på en indirekte forbindelse mellom sekundærarbeidsgiver og arbeidstaker. 


\subsection{Nærmere om offentligrettslig grunnlag}

Avgjørelsen i Rt. 1985 s. 941 OIS er et eksempel på at sammensatte arbeidsgiverforhold kan etableres med grunnlag i offentligrettslige regler. Partsforholdet i saken kan illustreres slik:

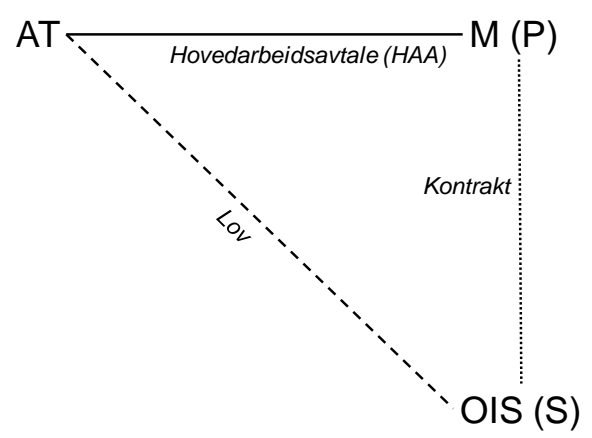

En gruppe arbeidstakere var ansatt i OIS' medlemsbedrift (M). M var underleverandør av blant annet arbeidstakere til OIS, som benyttet seg av arbeidskraften til å utføre oppdrag. I denne sammenheng skulle OIS sørge for at arbeidstakerne fikk tilstrekkelig sikkerhetsopplæring, men ikke alle fikk denne opplæringen. Spørsmålet var om OIS kunne holdes ansvarlig som «arbeidsgiver» for at arbeidsmiljølovens vernebestemmelser ikke var ivaretatt, jf. aml. (1977) § 4. Det var på det rene at M var arbeidsgiver for arbeidstakerne. Selv om det ikke fulgte av arbeidsavtalene, fant Høyesterett likevel at OIS var ansvarlig som arbeidsgiver overfor arbeidstakerne. OIS var arbeidstakernes sekundærarbeidsgiver.

\subsection{Nærmere om privatrettslige grunnlag}

Avgjørelsene i ExLog-saken ${ }^{37}$ er gode eksempler på at et sammensatt arbeidsgiverforhold kan oppstå på avtalemessig grunnlag - et såkalt dobbelt arbeidsavtaleforhold. Noen arbeidstakere var ansatt i utenlandske ELU; selskapet var primærarbeidsgiver (P). I hovedarbeidsavtalene var det inntatt bestemmelser om flytteplikt innenfor selskapsgruppen. Arbeidstakerne ble utplassert til norske ELN, men motsatte seg deretter videre flytting på bakgrunn av at ELN måtte være deres arbeidsgiver. Kjæremålsutvalget fant at arbeidstakerne hadde arbeidsforhold med ELN. Ved den senere behandlingen i Høyesterett kom imidlertid retten til at flytteplikten etter hovedarbeidsavtalene med ELU fortsatt måtte gjelde. Både ELU og ELN ble dermed ansett for å være arbeidsgivere for arbeidstakerne. 
Hovedarbeidsavtalene etablerte en direkte forbindelse mellom sekundærarbeidsgiver (ELN) og arbeidstakerne; de sammensatte arbeidsgiverforholdene hadde avtalemessig grunnlag.

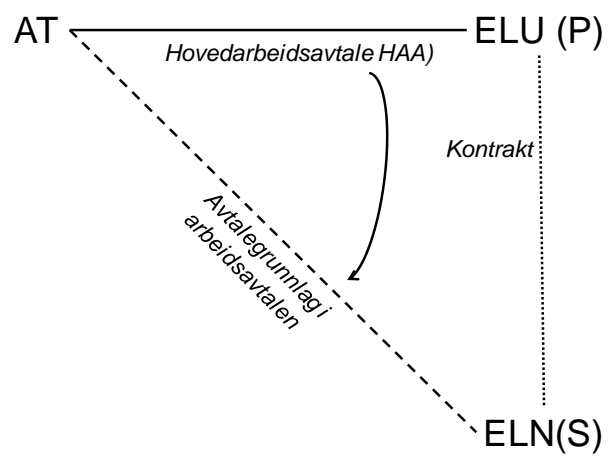

Dommen i Rt. 1990 s. 1126 Wärtsilä er et eksempel på at sammensatte arbeidsgiverforhold på privatrettslig grunnlag også kan etableres gjennom indirekte forbindelser mellom sekundærarbeidsgiver og arbeidstaker. Saken gjaldt en arbeidstaker som opprinnelig var ansatt i det finske morselskapet $\mathrm{OW}$, men som hadde fått arbeidsforholdet overført til det norske datterselskapet WD. Hovedarbeidsavtalen med datterselskapet inneholdt imidlertid bestemmelser om rettigheter og plikter mellom arbeidstakeren og OW, herunder en rett for arbeidstakeren til å vende tilbake til sin gamle stilling når arbeidsforholdet med WD opphørte. Høyesterett konkluderte først med at WD var arbeidsgiver for arbeidstakeren; WD var primærarbeidsgiver. Etter en samlet vurdering av forbindelsen mellom arbeidstakeren og OW og "forretningsforholdet" mellom OW og WD, fant retten at OW også var arbeidsgiver «i den forbindelse som her [var] aktuell» (s. 1132); OW var sekundærarbeidsgiver.

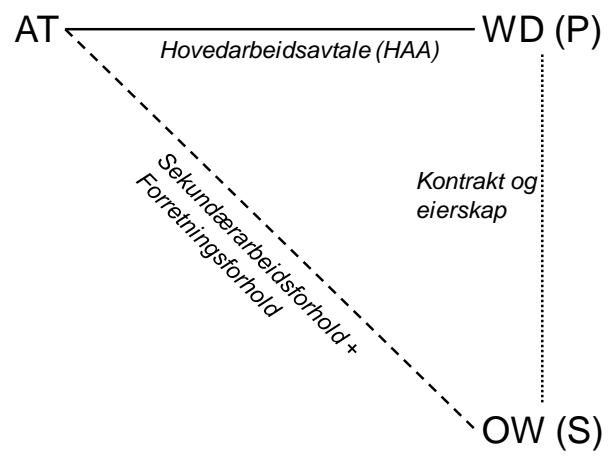

\subsection{Virksomhetsbegrepets betydning for ansvarsplasseringen}

Arbeidsmiljølovens anvendelsesområde er i utgangspunktet avgrenset til «virksomhet som sysselsetter arbeidstaker», jf. § 1-2. Begrepet virksomhet ble introdusert med arbeidsmiljøloven av 1977. Arbeidervernloven (1956) anvendte begrepet bedrift. Endringen var ikke 
ment å innebære noen «vesentlige realitetsendringer, idet bedriftsbegrepet ... [hadde] blitt

fortolket sterkt utvidende». ${ }^{38}$ Språklig sett kan imidlertid virksomhet ha to betydninger: For det første kan det brukes om foretak eller bedrift, som forutsatt i forarbeidene. For det andre kan "virksomhet" være en betegnelse på aktivitet.

Virksomhetsbegrepet har en nedre grense. Grensedragningen har betydning for om det i det hele tatt foreligger et arbeidsforhold som reguleres av arbeidsmiljøloven, jf. lovens anvendelsesområde etter $\S 1-2$. I ARD 1981 s. 49 gjorde Arbeidsretten nærmere rede for denne grensen. Med utgangspunkt i Ot.prp. nr. 31 (1935) la Arbeidsretten til grunn at virksomheten måtte ha en «fast organisasjon, en viss varighet eller stabilitet og ... ikke være rent ubetydelig». Videre måtte virksomhetens formål «søkes oppnådd ved underordning av personer under en annens vilje» (s. 56). Høyesteretts kjæremålsutvalg tiltrådte avgjørelsen og begrunnelsen i Rt. 1981 s. 899 (s. 902).

I arbeidsmiljøloven støter man på virksomhetsbegrepet i ulike sammenhenger. I tilknytning til stillingsvernet kan arbeidstakeren ha rett til annet passende arbeid innen virksomheten, se eksempelvis $§ 15-7(2)$ om vern mot usaklig oppsigelse. Videre kan virksomhetsbegrepet være sentralt ved plasseringen av arbeidsgivers ansvar, jf. ansvarliggjøringen av den som leder «virksomheten» i $\S 19-1$. Virksomheten er dermed en "referanseenhet" for arbeidsgivers plikter etter loven. I lovens forarbeider er det sagt om arbeidsgiverbegrepet at:

«Som alminnelig regel vil det rettsubjekt som er arbeidsgiver være sammenfallende med arbeidsgivers virksomhet. For de fleste praktiske tilfeller vil en virksomhet være det som etter alminnelig språkbruk er en bedrift. Hovedregelen er at arbeidstakers rettigheter er knyttet til den enkelte virksomhet.» ${ }^{39}$

Som hovedregel vil altså det rettssubjektet som er arbeidsgiver sammenfalle med arbeidsgivers virksomhet i betydningen foretak, juridisk person. Det forekommer imidlertid unntak, typisk på grunnlag av at flere foretak identifiseres. Et eksempel på dette er Rt. 1993 s. 345 Matherson-Selig, som omtales nærmere under avsnitt 4.6.

Jf. Ot.prp. nr. 3 (1975-76) s. 101.

39 Jf. Ot.prp. nr. 49 (2004-2005) s. 74. 


\section{Sammensatte arbeidsgiverforhold i relasjon til HMS}

\subsection{Innledende bemerkninger}

Et av arbeidsmiljølovens overordnede formål er å sikre et trygt arbeidsmiljø, jf. §1-1(a). Arbeidsgivers posisjon $\mathrm{i}$ arbeidsforholdet tilsier at arbeidsgiver har hovedansvaret for at lovens bestemmelser overholdes, jf. $§ 2-1$. Det følger av forarbeidene at «bakgrunnen for å legge hovedansvaret for arbeidsmiljøet på arbeidsgiver har vært at arbeidsgiver gjennom sin styringsrett er den som har myndighet til å ta og iverksette nødvendige tiltak for å bedre arbeidsmiljøet, og en oppfatning om at arbeidstaker er den svake part». ${ }^{40}$ Ved utarbeidelsen av § 2-1 ble det lagt til grunn at « [d] et er et grunnleggende og uomtvistet prinsipp ... at arbeidsgiver har hovedansvaret for at lovens krav etterleves». ${ }^{41}$ Bestemmelsen tok utgangspunkt i aml. (1977) § 14(1). I forarbeidene til den bestemmelsen fors $\varnothing$ kte lovgiver å ta hensyn til at loven skulle regulere virksomheter som bestod av personer med ulike muligheter til å påvirke arbeidsplassen. Plasseringen av ansvar måtte derfor bygge på «de tre grunnleggende forutsetninger for den individuelle arbeidsavtale, nemlig arbeidsgiverens styringsrett, arbeidstakerens arbeids- og lydighetsplikt, og arbeidsgiverens omsorgsplikt». ${ }^{42}$ Bestemmelsen i aml. (2005) § 2-1 bygger etter mitt skjønn også på disse forutsetningene.

I dette kapittelet analyseres de forhold som lå til grunn for at sammensatte arbeidsgiverforhold ble ansett for å være etablert i relasjon til HMS-ansvaret. Når arbeidsgiver i relasjon til HMS-ansvaret er identifisert, plasseres ansvaret for en eventuell overtredelse hos enten en fysisk eller en juridisk person innen arbeidsgivers organisasjon, jf. $\S 19-1$ og 19-3.

Høyesterett har tatt stilling til problemstillinger knyttet til HMS-ansvaret i sammensatte arbeidsgiverforhold i spesielt to avgjørelser. I Rt. 1985 s. 941 OIS var spørsmålet om OIS som vertsselskap for utplasserte arbeidstakere var deres arbeidsgiver i relasjon til HMSbestemmelsene (jf. omtalen foran under punkt 2.42). I Rt. 1990 s. 419 Asbest tok retten stilling til om et byggelederselskap var arbeidsgiver for medlemmene av et engasjert

Jf. Arbeidslivsutvalgets utredning i NOU 1999: 34 punkt 7.3.2. Utvalgets mandat var «å legge premisser for en fremtidig gjennomgang av reguleringssystemet i arbeidslivet, med særlig vekt på arbeidsmiljøloven», jf. punkt 1.2. Resultatet var dermed en slags «forutredning» til arbeidsmiljøloven av 2005.

Jf. Ot.prp. nr. 49 (2004-2005) s. 89.

42 Ot.prp. nr. $3(1975-76)$ s. 31. 
musikkorps, jf. aml (1977) §4(1), og om selskapets daglige leder og ansvarlige prosjektleder «lede[t] virksomheten» $\mathrm{i}$ arbeidsgivers sted, jf. § 4(2). Innledningsvis gjennomgås imidlertid Rt. 1982 s. 645 Krankjennelsen, som i begge de to nevnte avgjørelsene ble anvendt som prejudikat, i sammenheng med den rettslige vurderingen av om sammensatte arbeidsgiverforhold forelå.

\subsection{Rt. 1982 s. 645 Krankjennelsen}

\subsection{Avgjørelsens relevans for sammensatte arbeidsgiverforhold}

Krankjennelsen gjelder egentlig ikke arbeidsgiveransvaret. Den rettslige problemstillingen for Høyesterett var om en byggherre var ansvarlig for overtredelser begått av entreprenør etter foretaksansvaret i aml. (1977) $\$ 87$. Senere avgjørelser om sammensatte arbeidsgiverforhold i relasjon til HMS-ansvaret har imidlertid vist til denne avgjørelsen som et prejudikat for at flere selskaper sammen kan være ansvarlige for at arbeidsmiljøloven er overtrådt, ${ }^{43}$ og for at ansvarsplasseringen beror på en konkret vurdering. ${ }^{44}$ Derfor er det grunn til å behandle Krankjennelsen her.

\subsection{Saken}

Aksjeselskap A ga byggeavdelingen i firma B i oppdrag å oppføre en bygning. Ingeniøren C, som var ansvarlig leder for byggeavdelingen i B, ledet arbeidet. Til oppføringen benyttet C seg av en kran som tilhørte A, i strid med pålegg fra Arbeidstilsynet. Verneombudet hos A hadde gjort $\mathrm{C}$ oppmerksom på at kranen ikke kunne benyttes, og Cs søknad om dispensasjon var blitt avslått. Som følge av den rettsstridige bruken ble forelegg utferdiget mot $\mathrm{C}$ og A for brudd på henholdsvis aml. (1977) $\S \S 85$ og 87. Herredsretten idømte C en bot, men frifant A. Frifinnelsesdommen ble anket til Høyesterett, som forkastet anken.

Spørsmålet for Høyesterett var om en byggherre kunne bli ansvarlig for overtredelser begått under utførelsen av entreprenørens aktivitet. Retten bemerket at det samme måtte gjelde «i andre tilfelle hvor det [var] en oppdragsgiver og en selvstendig oppdragstaker» (s. 646).

\subsection{Analyse og vurdering}

Høyesterett anså herredsrettens domsgrunner som tilstrekkelige til at lovanvendelsen kunne prøves. Avgjørelsen av spørsmålet om en oppdragsgiver kunne bli ansvarlig for 
overtredelser, begått under en selvstendig oppdragstakers arbeidsutførelse, måtte bero på en «vurdering av de konkrete forhold». Vurderingstemaet var om $\mathrm{C}$ kunne sies å ha handlet på vegne av A, jf. § 87. På bakgrunn av formålet med straffebestemmelsen måtte det vurderes om oppdragsgiver hadde hatt en «reell myndighet til instruksjon og kontroll», og om vedkommende hadde hatt noen «økonomisk interesse i overtredelsen» (s. 646).

I det konkrete tilfellet var A og B «selvstendige, uavhengige selskaper» som i det vesentlige hadde «forskjellige eierinteresser» (s. 646). Oppdraget gjaldt en eiendom som var eid av B, men delvis bortleid til A. Det ble også lagt vekt på at overtredelsen skjedde under Bs oppdragsutførelse, og at Bs representant C ledet arbeidet. C besluttet også selvstendig å benytte seg av kranen, og den ble ført av Bs folk. A på sin side protesterte mot bruken av kranen, og eierskapet kunne etter rettens oppfatning ikke få noen vesentlig betydning.

\subsection{Sammenfatning}

Høyesterett la til grunn at en oppdragsgiver kunne bli ansvarlig for det som skjedde under den selvstendige oppdragstakers utførelse av arbeidet. Ansvarsplasseringen måtte bero på en konkret vurdering, hvor økonomiske interesser og instruksjonsmulighet var sentrale momenter. Konstellasjonen mellom saksaktørene kan illustreres som følger:

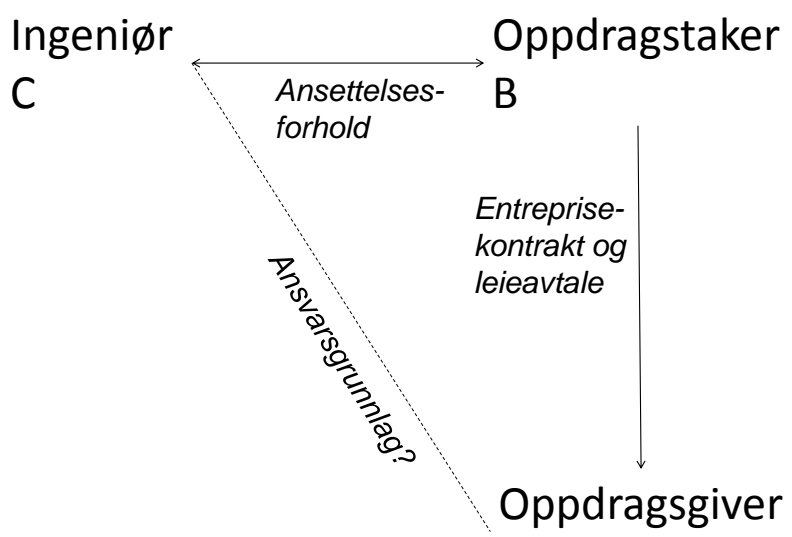

A

Høyesterett fant at det ikke var grunnlag for å holde A ansvarlig for Cs overtredelser. I premissene ble det imidlertid åpnet for at selskaper som står i kontraktsforhold med hverandre, kan holdes ansvarlig for det som skjer i kontraktmotpartens virksomhet. 


\subsection{Rt. 1985 s. 941 OIS}

\subsection{Faktum og problemstilling}

Saken gjaldt et forelegg mot Oil Industry Services A/S (OIS) for overtredelse av aml. (1977) § 87, jf. § 14(2)(h), jf. nærmere omtale under punkt 2.42 foran. ${ }^{45}$ I forelegget var det lagt til grunn at noen som hadde handlet på selskapets vegne, ikke hadde sørget for at nødvendig sikkerhetsopplæring var gitt til arbeidstakere (AT) som selskapet var arbeidsgiver for. Arbeidstakerne var opprinnelig ansatt i OIS' ulike medlemsbedrifter (M), og var utplassert hos OIS for å utføre oppdrag som selskapet hadde påtatt seg for en utenforstående oppdragsgiver (OG). OIS fungerte dermed som «vertsforetak» for arbeidstakerne under oppdragsutførelsen. For Høyesterett gjorde OIS gjeldende at selskapet måtte frifinnes fordi det ikke hadde tilsatt arbeidstakerne og dermed ikke kunne være arbeidsgiveren deres, jf. §4. Høyesterett vurderte situasjonen slik den fremsto under arbeidstakernes tjenesteopphold hos OIS, og sluttet seg til byrettens begrunnelse for at OIS var å anse som arbeidsgiver. Arbeidstakerne ble dermed ansett for å ha to arbeidsgivere. Imidlertid ble byrettens frifinnende dom opphevet på bakgrunn av feil rettsanvendelse og utilstrekkelige domsgrunner med hensyn til straffbarheten av arbeidstakernes manglende opplæring.

Høyesterett fant at både M og OIS var arbeidsgivere for de utplasserte arbeidstakerne. Partsforholdene kan illustreres slik:

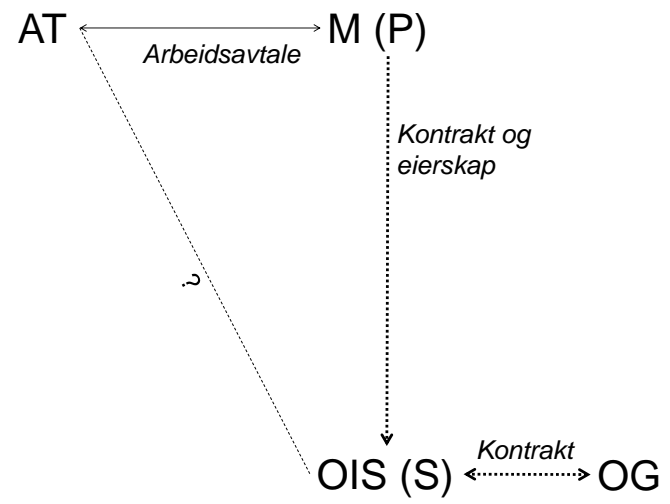

Min problemstilling i det følgende er å kartlegge det rettslige grunnlaget retten baserte sin konklusjon på. 


\subsection{Analyse og vurdering}

Det var ingen tvil om at arbeidstakerne i utgangspunktet var ansatt i M. Grunnlaget for arbeidsforholdet var arbeidsavtale, og M stod for avlønning, skattetrekk, arbeidsgiveravgift, sosiale utgifter og lignende. Forholdet mellom $M$ og arbeidstakerne var i denne sammenheng "primærarbeidsforholdet"; $M$ var primararbeidsgiver $(P)$.

OIS anførte at arbeidstakerne etter sine arbeidsavtaler var ansatt i M, og ikke i OIS. Det forelå ingen direkte kontraktsrelasjon mellom arbeidstakerne og OIS, og vilkåret om å ha tilsatt arbeidstakerne etter aml. (1977) $§ 4$ kunne følgelig ikke være oppfylt. Ansvaret etter $\S 14$ kunne bare gjøres gjeldende overfor «arbeidsgiver», og OIS påstod seg derfor frifunnet. Høyesterett var ikke enig i dette.

Høyesterett sluttet seg til byrettens begrunnelse for at OIS var å anse som «arbeidsgiver», men tilføyde samtidig at også andre momenter fra byrettens premisser begrunnet resultatet. Høyesterett refererte først til enkelte momenter ved forholdet mellom OIS og OG, som at arbeidstakerne etter avtalen skulle betraktes som OIS-folk, og at OIS stod ansvarlig for arbeidets utførelse. Deretter ble det uttalt at:

«Disse momenter sammen med den arbeids- og ansvarsfordeling som byretten også har pekt på, utgjør typiske elementer i den styringsrett som følger med arbeidsgiverposisjonen» (s. 943).

Spørsmålet om OIS var «arbeidsgiver» etter $\S 4$ ble avgjort ut fra en samlet vurdering av de konkrete forhold. Vurderingstemaet var om OIS reelt sett hadde en arbeidsgiverposisjon overfor arbeidstakerne. I denne saken var det avgjørende forholdet at OIS' posisjon overfor AT hadde typiske elementer av den styringsretten som følger med arbeidsgiverposisjonen. Om man snur argumentet, så anså retten arbeidsgiverposisjonen som en forutsetning for slik styringsrett. OIS var dermed arbeidsgiver for arbeidstakerne ved siden av M; OIS var sekundararbeidsgiver (S).

I henhold til avtalen mellom OIS og OG skulle «alt personell under arbeidet offshore betraktes som [OIS]-folk». OIS stod også ansvarlig for arbeidenes utførelse overfor OG; selskapet hadde en resultatforpliktelse overfor oppdragsgiver. Disse forholdene ga klare holdepunkter for at OIS var selvstendig oppdragstaker, ikke en tilbyder av arbeidskraft, og at selskapet dermed stod nærmest til å ha ansvaret for arbeidsstokken som ble benyttet til å utføre oppdraget. Videre var det OIS som skulle sørge for at arbeidstakerne hadde den nødvendige sikkerhetsopplæringen. Overtredelsen gjaldt altså et forhold som OIS var ansvarlig for. 
Med hensyn til "forretningsforholdet" mellom OIS og M viste Høyesterett til byrettens vurdering av den arbeids- og ansvarsfordelingen som var avtalt mellom dem. OIS sørget for «koordinering av de enkelte arbeidsoperasjoner». Bakgrunnen for dette lå i at OIS ble stiftet av M for å «skaffe medlemsbedriftene oppdrag gjennom koordinering av bedriftenes ressurser som leverandører av materiell, utstyr, service og konsulentytelser». Forbindelsen mellom OIS og M bestod dermed av et samspill av eierskap og kontrakt. OIS inngikk så samarbeidsavtale med OG. I henhold til avtalen skulle OIS være «kontraktsansvarlig» overfor OG og sørge for en egen «safety-tjeneste». Samtidig ga OIS beskjed til M om forestående arbeid og behovet for arbeidskraft, både med hensyn til antall arbeidstakere og hvilke kvalifikasjoner disse måtte ha. Etter kontraktene med OIS var Ms oppgave å opptre som underleverandører av ytelser og tjenester til OIS. M sørget på sin side for å oppdrive den etterspurte arbeidskraften, og ordnet selv med «avlønning og ordning av skattetrekk, arbeidsgiveravgift, sosiale utgifter etc.»; de hadde med andre ord ansvaret for store deler av de фkonomiske og administrative arbeidsgiverfunksjonene (s. 945).

For ytterligere å belyse hvilke momenter som utgjorde typiske elementer i styringsretten, og som følgelig ga grunnlag for å anse OIS som arbeidsgiver, kan man se situasjonen fra arbeidstakernes perspektiv. Ms ansvar var som nevnt begrenset til arbeidsgiverfunksjoner av økonomisk og administrativ art. Det var etter alt å dømme ingen forbindelse mellom arbeidstakerne og OG. OIS utøvde instruksjon og kontroll overfor arbeidstakerne med hensyn til sikkerhetsopplæringen. Utad fremstod også AT som OIS’ arbeidstakere. På denne bakgrunn ble OIS ansett for å ha styringsretten over arbeidstakerne.

Høyesteretts konklusjon innebar som nevnt at OIS ble ansett for å være arbeidsgiver sammen med M. Førstvoterende uttalte i denne sammenheng at:

«Slik denne sak foreligger, vil jeg ikke unnlate å bemerke at det vel kan forekomme at flere bedrifter innenfor en "paraply-organisasjon" som [OIS] i enkelte relasjoner hensett til de konkrete forhold - kan bli å anse som arbeidsgiver. Jeg finner en viss støtte for dette synspunkt også i avgjørelse i Rt-1982-645» (s. 943).

Uttalelsen består av flere elementer. For det første la Høyesterett til grunn at det var en adgang til å anse flere bedrifter for å være arbeidsgivere i samme arbeidsforhold. For det andre ble det påpekt at dersom flere bedrifter ble ansett for å være arbeidsgivere, ville en slik arbeidsgiverposisjon innebære at de involverte aktørene ble arbeidsgivere $i$ enkelte relasjoner. For det tredje bekreftet retten at en bedrift kunne bli ansett for å være arbeidsgiver hensett til de konkrete forhold. OIS' anførsel om at arbeidsmiljøloven av 1997 $\S 4$ inneholdt et vilkår om formell tilsetting ble dermed forkastet. Som støtte for sitt synspunkt viste Høyesterett til Rt. 1982 s. 645 Krankjennelsen, som er nærmere behandlet 
foran under avsnitt 3.2. Nærmere kommentarer til hva som kan utledes av disse avgjørelsene sett i sammenheng følger under avsnitt 3.5.

\subsection{Rt. 1990 s. 419 Asbest}

\subsection{Faktum og problemstilling}

Saken i Rt. 1990 s. 419 Asbest gjaldt plasseringen av ansvar for at det hadde foregått rivningsarbeider på et sted med forekomst av asbest. Byggherren $(\mathrm{BH})$ hadde engasjert et byggelederselskap (BL), som fungerte som koordinator mellom byggherren og de ulike oppdragstakerne i prosjektet. Ansvarlig prosjektleder (AP) var byggelederselskapets representant på arbeidsplassen. Et lokalt musikkorps (MK) ba om engasjement på byggeplassen gjennom et korpsmedlem, som også var ansatt hos BL. Inntektene skulle finansiere en korpstur. De inngikk muntlig avtale med AP om å få drive rivningsarbeid. Under rivningen kom det fram at det nedrevne materialet inneholdt asbest, og i kjølvannet av dette ble BL, daglig leder i BL og AP bøtelagt for overtredelse av arbeidsmiljølovens vernebestemmelser etter aml. (1977) $\S 14$. Herredsretten stadfestet bøtene, og anken ble forkastet av Høyesterett.

Hovedspørsmålet for Høyesterett var om BL var arbeidsgiver for korpsmedlemmene (AT) etter aml. (1977) $\S 4$. Dette var en forutsetning for arbeidsgiveransvar etter $\S 14$. Selve straffeutmålingen etter $\S \S 85$ og 87 behandles under avsnitt 3.6 og 3.7.

\subsection{Analyse og vurdering}

I min analyse av Asbest-kjennelsen anser jeg MK som primaerarbeidsgiver $(P)$, til tross for at korpsmedlemmene ikke var ansatt som sådan. Jeg viser i denne sammenheng til herredsrettens premisser:

«I utgangspunktet var [MK], slik retten forstår dets funksjon, en selvstendig oppdragstaker med et begrenset arbeidsoppdrag på lik linje med de øvrige firmaer som deltok i prosjektet. Retten vil i den forbindelse peke på at utbetalingen til [MK] ble gjort samlet, og ikke til det enkelte medlem. Byggeleder hadde videre ingen opptegnelse eller oversikt over hvilke individer [MK] benyttet. En hel del av utstyr og verktøy var skaffet til veie av $[\mathrm{MK}]$ selv. $[\mathrm{MK}]$ organiserte videre selv medlemmene i grupper og førte kontroll med hvem som møtte og hvor lenge den enkelte arbeidet. På denne bakgrunn ble en hel del av den normale arbeidsgiverfunksjonen ivaretatt av [MK] selv. Det vises her til lovens $\S 4,1$. ledd hvoretter arbeidsgiver er enhver som har tilsatt arbeidstakere for å utføre arbeid i sin tjeneste. På denne bakgrunn kan det hevdes at det enkelte bandmedlem 
utførte arbeid for $[\mathrm{MK}]$, og videre at $[\mathrm{MK}]$ hadde tilsatt det enkelte medlem for å få utført det arbeidet $[\mathrm{MK}]$ hadde påtatt seg.» ${ }^{46}$

Med dette utgangspunktet er spørsmålet om det var etablert et "sekundærarbeidsforhold" mellom korpsmedlemmene og BL; om BL var sekundararbeidsgiver $(S)$.

"Forretningsforholdet" mellom MK og BL baserte seg på muntlig avtale mellom MK og $\mathrm{AP}$, på vegne av BL. I denne sammenheng var MK oppdragstaker og BL oppdragsgiver. Det forelå ingen kontraktsmessig relasjon mellom BL og korpsmedlemmene. MK hadde imidlertid inngått en muntlig oppdragsavtale med BL, med AP som mellommann. Under selve arbeidet opptrådte $\mathrm{AP}$ som representant for $\mathrm{BL}$, med full instruksjonsrett over korpsmedlemmene. Partsforholdet kan illustreres slik:

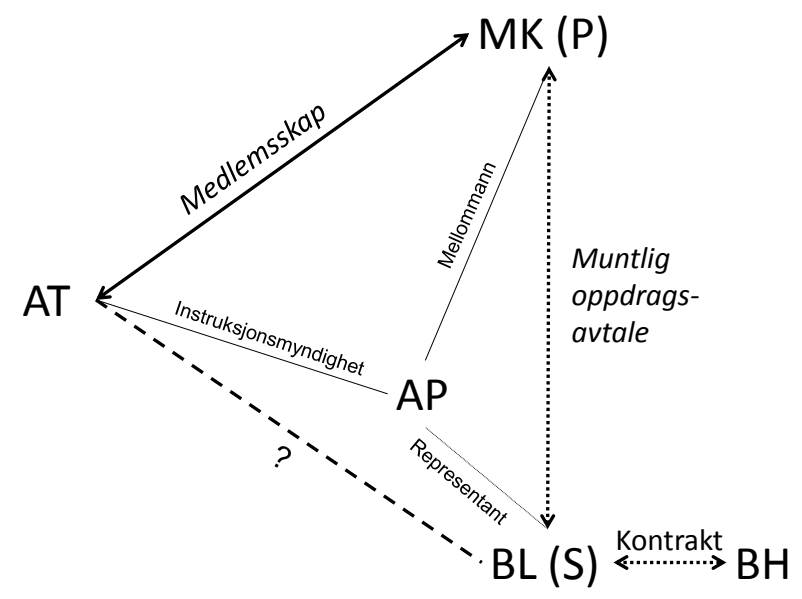

Ved behandlingen av spørsmålet om BL var å anse som korpsmedlemmenes arbeidsgiver, bemerket førstvoterende innledningsvis at:

«Jeg er enig med herredsretten $\mathrm{i}$ at arbeidsmiljøloven [1977] § 4 sammenholdt med lovforarbeidene ikke entydig løser spørsmålet. Herredsretten har foretatt en konkret vurdering hvor den - også med støtte i lovens formålsbestemmelse - har lagt vekt på en rekke forhold som den utførlig har gjort rede for. En slik konkret helhetsbedømmelse er etter mitt syn helt i tråd med den konkrete vurdering Høyesterett tidligere har gitt anvisning på, jf. bla uttalelser i Rt-1982-645 og Rt-1985-185» (s. 422).

Herredsretten hadde som nevnt over tatt utgangspunkt $i$ at MK ivaretok flere arbeidsgiverfunksjoner. Herredsretten konkluderte imidlertid med at: 
«Spørsmålet blir imidlertid om denne beskrivelsen er fullt ut dekkende for den faktiske situasjon slik at det etter en samlet vurdering kan sies at [MK] både formelt og reelt ivaretok arbeidsmiljølovens arbeidsgiveransvar. Retten finner imidlertid at dette ikke er tilfellet.» ${ }^{47}$

På denne bakgrunn foretok herredsretten en «konkret vurdering» av sakens faktum for å avgjøre om BL kunne anses for å være arbeidsgiver. Lovens formålsbestemmelse ble ansett for å støtte en slik vurdering. Etter bestemmelsen skulle loven sikre «et arbeidsmiljø som [ga] arbeidstakerne full trygghet mot fysiske og psykiske skadevirkninger», jf. aml. (1977) $\S 1$ (1). Høyesterett sluttet seg som nevnt til disse synspunkter (s. 422). Spørsmålet om BL var arbeidsgiver skulle dermed etter Høyesteretts oppfatning avgjøres ut fra en konkret helhetsvurdering.

Etter dette kommenterte Høyesterett den konkrete vurderingen herredsretten hadde foretatt. Det ble innledningsvis bemerket at herredsretten hadde lagt vekt på en rekke forhold som var utførlig gjort rede for. Høyesterett fant grunn til å trekke fram enkelte av disse. For det første innebar rivningsarbeidet «særlige faremomenter». Korpsmedlemmene, og dermed også MK, hadde verken kunnskaper eller erfaringer om arbeidet eller risikoen forbundet med det. Slik kunnskap hadde imidlertid AP, som opptrådte som byggelederselskapets representant under arbeidet. For det andre hadde AP «full instruksjonsmyndighet» over korpsmedlemmene (s. 422). Høyesterett fremhevet momenter som gikk på faglig kompetanse og myndighet til å bestemme hvordan arbeidet skulle utføres. Momentene talte for at BL gjennom AP hadde bedre forutsetninger for å ivareta lovens formålsbestemmelse enn MK.

Av momenter Høyesterett ikke nevnte i vurderingen, var at korpset selv organiserte seg i grupper og førte kontroll med arbeidstimene. Utbetaling av vederlag skjedde også til korpset som helhet, og gikk videre til korpsets reisekasse. Arbeidsgiverfunksjoner av mer фkonomisk og administrativ karakter lå altså hos korpset, uten at dette ble tillagt vekt ved vurderingen.

Høyesterett fant at rettspraksis ga støtte til den konkrete vurderingen som var foretatt. Det ble i denne sammenheng vist til uttalelser i Rt. 1982 s. 645 Krankjennelsen og Rt. 1985 s. 185 Kraftverk. En nærmere gjennomgang av hvilke slutninger som kan trekkes av disse avgjørelsene sett i sammenheng følger under avsnitt 3.5. 
Avslutningsvis tiltrådte Høyesterett den helhetsvurderingen herredsretten hadde foretatt, når den konkluderte med at:

«... et annet tolkningsresultat enn det retten var kommet til, ville pulverisere ansvaret og dermed praktisk sett la det forsvinne, ...» (s. 422).

Dersom BL ikke ble ansett for å være arbeidsgiver, ville MK blitt stående igjen med ansvaret for korpsmedlemmene. I realiteten ville dette innebære at korpsmedlemmene, som ikke kjente til faremomentene ved arbeidet, selv hadde ansvaret for at de ble eksponert for asbest under oppdragsutførelsen. For at arbeidsgiveransvaret etter $\S 14$ skulle kunne plasseres hos de som hadde muligheten til å hindre asbesteksponering, uten at denne muligheten ble benyttet, måtte BL anses for å være «arbeidsgiver» etter $\S 4$.

\subsection{Sammenfatning og slutninger fra analysene}

Som analysene foran under avsnittene 3.3 og 3.4 viser, la Høyesterett til grunn i OISkjennelsen og Asbest-kjennelsen at arbeidstakerne hadde to arbeidsgivere $\mathrm{i}$ samme arbeidsforhold; arbeidsgiverforholdene var sammensatt. ${ }^{48}$ I dette avsnittet omtaler jeg korpsmedlemmene som arbeidstakere. De sammensatte arbeidsgiverforholdene bestod først og fremst av "primærarbeidsforhold" mellom arbeidstakerne og deres primærarbeidsgivere, i analysene omtalt som M og MK. I tillegg hadde tredjepersoner - OIS og BL forbindelser med arbeidstakerne og deres respektive primærarbeidsgivere som førte til at de var å anse som sekundærarbeidsgivere. Sekundærarbeidsgiverne var tilknyttet primærarbeidsgiverne gjennom "forretningsforhold" og arbeidstakerne gjennom "sekundærarbeidsforhold".

Ettersom saksforholdene gjaldt offentligrettslige sanksjoner, var spørsmålet om S på offentligrettslig grunnlag var å anse som arbeidsgiver, se nærmere om dette under punktene 2.41 og 2.42. I OIS-saken vurderte Høyesterett om OIS var arbeidsgiver etter aml. (1977) $\S 4$. I Asbest-saken tok Høyesterett utgangspunkt i at spørsmålet ikke entydig kunne løses ut fra $\S 14$ sammenholdt med forarbeidene. Høyesterett sluttet seg til den konkrete vurderingen herredsretten hadde lagt til grunn, hvor den med støtte i lovens formålsbestemmelse fant at BL var å anse som arbeidstakernes arbeidsgiver etter $\S 4$. BL ble dermed ansett som $\mathrm{S}$ med hjemmel i loven. Begge arbeidsforhold kan følgelig omtales som tilfeller av lovbasert delte arbeidsgiverposisjoner. 
I OIS-saken konkluderte Høyesterett som nevnt med at både $\mathrm{M}$ og OIS var arbeidsgivere for AT. Dette foranlediget en kommentar om i hvilken grad flere rettssubjekter kunne være arbeidsgivere i samme arbeidsforhold. Retten la til grunn at flere bedrifter innenfor en "paraply-organisasjon" kunne bli å anse som arbeidsgivere i samme arbeidsforhold. Spørsmålet er om retten med dette oppstilte en skranke mot andre konstellasjoner, eller om det var ment som et forbehold om at andre selskapskonstellasjoner kunne bli bedømt annerledes. En kan vanskelig svare på dette spørsmålet ut fra OIS-saken alene. Som støtte for sitt synspunkt viste imidlertid retten til Rt. 1982 s. 645 Krankjennelsen. Som nevnt under punkt 3.2 gjaldt den avgjørelsen plassering av foretaksansvaret; ikke arbeidsgiveransvaret. Til tross for dette anså Høyesterett avgjørelsen for å ha relevans. Krankjennelsen gjaldt spørsmålet om ansvaret for brudd på arbeidsmiljøbestemmelsene kunne plasseres hos oppdragsgiver, til tross for at overtredelsen var skjedd under oppdragstakers utførelse av arbeidet. Oppdragstakers representant var allerede holdt ansvarlig. Oppdragsgiver og oppdragstaker var selvstendige selskaper med forskjellige eierinteresser. De tilhørte følgelig ingen "paraply-organisasjon". I denne sammenheng kan henvisningen til Krankjennelsen tas til inntekt for at det ble åpnet for en plassering av ansvar etter arbeidsmiljøloven hos oppdragsgiver og oppdragstaker sammen. I OIS-saken bekreftet så Høyesterett at dette måtte gjelde i tilknytning til arbeidsgiveransvaret, i hvert fall for selskaper innen samme "paraply-organisasjon". Etter mitt skjønn kan dette sees som en trinnvis rettsskapende virksomhet av Høyesterett. Retten oppstilte ikke en generell regel om flere med arbeidsgiveransvar etter arbeidsmiljølovens bestemmelser, men åpnet for at en slik regel kunne bli utviklet dersom lignende problemstillinger kom opp for domstolene.

I Høyesteretts avgjørelse i Asbest-saken inntok problemstillingen om sammensatte arbeidsgiverforhold og flere arbeidsgivere en mer tilbaketrukket rolle, enn den gjorde i herredsrettens dom i samme sak. Som en konsekvens av dette var det ikke naturlig for Høyesterett å kommentere adgangen til flere arbeidsgivere nærmere. Høyesterett fremhevet imidlertid at en annen løsning enn at BL var arbeidsgiver, ville pulverisere ansvaret. Bestemmelsen i aml. (1977) § 14 hjemlet et ansvar for arbeidsgiver overfor egne arbeidstakere. Dersom korpsmedlemmene ikke var blitt ansett som arbeidstakere i byggelederselskapet, ville dette selskapet ha vært fri for ansvar. I et slikt tilfelle kunne alternativt arbeidsgiveransvar for korpset blitt vurdert, men det ville i realiteten innebære at korpsmedlemmene fikk ansvaret selv. Ved å engasjere korpsmedlemmene gjennom korpset, og ikke som arbeidstakere, ville byggelederselskapet ha omgått ansvarsbestemmelsene i loven og vært uten ansvar for forhold som i utgangspunktet skulle medført straffansvar som arbeidsgiver. En slik løsning anså Høyesterett tilsynelatende for å være uaktuell. På denne bakgrunn måtte BL anses som arbeidsgiver etter arbeidsmiljøloven. 
Både i OIS-saken og i Asbest-saken la Høyesterett en konkret vurdering til grunn, for å ta stilling til om S var «arbeidsgiver» for arbeidstakerne, jf. aml. (1977) § 4. En slik konkret vurdering fant retten støtte for i tidlige avgjørelser. Asbest-saken gjaldt spørsmål om plasseringen av ansvar hos "ledere av virksomheten" etter aml. (1977) § 85 og hos foretaket etter $\S 87$. Høyesterett fant støtte for den konkrete vurderingen for virksomhetslederansvaret i Krankjennelsen og for foretaksansvaret i Kraftverk-kjennelsen. ${ }^{49}$. I OISsaken, som kun gjaldt plasseringen av foretaksansvaret, nøyde Høyesterett seg med å vise til Krankjennelsen. Spørsmål om sammensatte arbeidsgiverforhold ble ikke behandlet av Høyesterett i noen av disse kjennelsene, men Høyesterett la i kjennelsene til grunn at arbeidsgivers ansvar skulle plasseres ut fra en konkret vurdering. Etter min oppfatning tok Høyesterett i OIS-saken og Asbest-saken disse synspunktene til inntekt for at samme vurdering kunne legges til grunn når det skulle vurderes om det forelå et sammensatt arbeidsgiverforhold, ettersom dette ville ha direkte konsekvenser for ansvarsplasseringen. ${ }^{50}$

Som følge av at OIS-saken og Asbest-saken hadde ulike faktum, var det ulike momenter som ble tillagt vekt i hvert tilfelle. Imidlertid er det mulig å se en felles struktur i de vurderingene retten la til grunn.

For det første ble "forretningsforholdet" mellom primær- og sekundærarbeidsgiver vurdert, sett i sammenheng med sekundærarbeidsgiverens forhold til utenforstående oppdragsgivere. I OIS-saken var det på det rene at OIS hadde ansvaret for arbeidstakerne under oppdragsutførelsen, både etter kontraktsforholdet med OG og etter "forretningsforholdet" med M. I Asbest-saken var det BL som hadde inngått avtale med MK om rivningsarbeidet. Byggelederselskapets kontraktspart, byggherren, stod utenfor dette forholdet. I "forretningsforholdet" mellom BL og MK la Høyesterett vekt på at musikkorpset manglet kunnskap og erfaringer om arbeidet og faremomentene knyttet til det. Uten at det i denne sammenheng ble kommentert nærmere, fremgår det av faktum at byggelederselskapets representant på byggeplassen - AP - kjente til risikoen for asbest. Etter min oppfatning tilla Høyesterett dette vekt, og identifiserte dermed AP med byggelederselskapet. "Forretningsforholdene" talte dermed for at sekundærarbeidsgiverne var nærmest til å sikre at arbeidsmiljøbestemmelsene i arbeidsmiljøloven ble overholdt. 
For det andre vurderte Høyesterett "sekundærarbeidsforholdene" mellom arbeidstakerne og sekundærarbeidsgiverne. I begge avgjørelsene la retten etter min mening vekt på at sekundærarbeidsgiverne hadde styringsretten over arbeidstakerne under arbeidsutførelsen. Dette går også uttrykkelig fram av Høyesteretts premisser i OIS-saken. I Asbest-saken hadde AP «full instruksjonsmyndighet» over arbeidstakerne under arbeidet. Som byggelederselskapets representant er det naturlig å identifisere AP med BL i denne sammenheng, slik at AP utøvde arbeidsgiverfunksjoner på vegne av BL. På bakgrunn av at musikkorpset hadde liten kunnskap om arbeidet, var det sannsynligvis AP som også kontrollerte arbeidet, både med hensyn til kvalitet og fremdrift. Dette gir grunnlag for å slutte at BL hadde styringsretten over arbeidstakerne under arbeidet. Styringsretten er en sentral arbeidsgiverfunksjon, og «følger med arbeidsgiverposisjonen». ${ }^{51}$ Ettersom denne kompetansen ble utøvet av sekundærarbeidsgiver, og ikke av primærarbeidsgiver, måtte sekundærarbeidsgiverne anses som «arbeidsgiver» etter $\S 4$. Arbeidsgiverfunksjoner av mer økonomisk og administrativ art, som i begge tilfeller ble utøvet av P, ble ikke tillagt vekt ved den konkrete vurderingen.

Etter dette kan det sluttes at dersom tredjeperson etter "forretningsforholdet" står nærmest til å sørge for at arbeidsmiljølovens bestemmelser om HMS overholdes, og samtidig har styringsrett over arbeidstaker, blir vedkommende å anse som ansvarlig som sekundaerarbeidsgiver $i$ relasjon til HMS-ansvaret. Vedkommende blir dermed sekundærarbeidsgiver i arbeidsforholdet mellom primærarbeidsgiver og arbeidstaker.

Når flere rettssubjekter er «arbeidsgivere» etter $\S 4$ i det samme arbeidsforholdet, oppstår spørsmål om hvilke konsekvenser dette får for arbeidsgiversidens aktører. Spørsmålet retter seg særlig mot det jeg kaller sekundærarbeidsgiveren, ettersom primærarbeidsgiverens posisjon og ansvar som hovedregel vil bestå uendret; vedkommende arbeidsgivers plikter reduseres ikke uten videre av at flere holdes ansvarlige. Høyesterett la i OIS-saken til grunn at flere kunne anses for å være arbeidsgivere «i enkelte relasjoner» (s. 943). Utsagnet kan tolkes på to måter. For det første kan det bety at Høyesterett oppstilte et skille mellom ulike relasjoner, og at det bare var aktuelt med flere arbeidsgivere i enkelte av dem. En slik betydning er etter min mening lite sannsynlig, ettersom retten ikke vurderte andre relasjoner enn den aktuelle. For det andre kan det bety at dersom flere blir ansett for å være arbeidsgivere i samme arbeidsforhold, typisk ved at en tredjeperson blir ansett for å være arbeidsgiver sammen med primærarbeidsgiver, så ville ikke dette automatisk innebære en 
arbeidsgiverposisjon i alle relasjoner. Alle plikter og rettigheter som etter arbeidsforholdet tilhører arbeidsgiver vil ikke med dette tilfalle tredjeperson. Tredjeperson vil bare være sekundærarbeidsgiver i enkelte relasjoner, avhengig av de konkrete forhold. I denne betydningen la Høyesterett til grunn at arbeidsgiverbegrepet er "relativt" i arbeidsforhold med flere arbeidsgivere; et relativt sekundararbeidsgiverbegrep. Tredjeperson kan være sekundærarbeidsgiver i relasjon til HMS-ansvaret, uten å være sekundærarbeidsgiver i relasjon til arbeidstakers stillingsvern. Det relative sekundærarbeidsgiverbegrepet blir mer utførlig behandlet under kapittel 5.

\subsection{Plasseringen av ansvar hos virksomhetsleder}

\subsection{Innledende bemerkninger}

Dersom arbeidsmiljøbestemmelsene er overtrådt, kan det reageres med straffesanksjoner, jf. § 19-1. Ettersom straffebestemmelsen forutsetter skyld, er det normalt den som "leder virksomheten" - virksomhetslederen - som straffes i kraft av den. Virksomhetsleder holdes dermed ansvarlig som arbeidsgiver for at arbeidsgivers HMS-ansvar ikke er ivaretatt, til tross for at vedkommende som hovedregel er en ansatt i de tilfeller hvor arbeidsgiver er en juridisk person.

Ansvarliggjøringen av virksomhetslederen innebærer at arbeidsgivers representant holdes ansvarlig for at arbeidsmiljølovens bestemmelser er overtrådt under arbeidsgivers aktivitet. Denne plasseringen av ansvar må ikke forveksles med foretaksansvaret etter $\S 19-3$, som regulerer ansvarliggjøringen av selve arbeidsgiverforetaket. Virksomhetslederansvaret innebærer at ansvaret plasseres på et lavere nivå i arbeidsgiverorganisasjonen enn dersom arbeidsgiverbedriften skulle holdes ansvarlig.

Hvorfor er så dette aktuelt i tilknytning til sammensatte arbeidsgiverforhold? Dersom en bedrift blir ansett for å være «arbeidsgiver» etter $\S 1-8(2)(1)$, vil dennes virksomhetsledere kunne holdes ansvarlige, selv om arbeidstakerne overtredelsen gjelder også har arbeidsforhold med en annen arbeidsgiver. Dette er noen av konsekvensene ved at et sammensatt arbeidsgiverforhold blir ansett for å være etablert. En slik ansvarsplassering var resultatet av Rt. 1990 s. 419 Asbest, som er nærmere omtalt foran under avsnitt 3.4. Høyesterett konkluderte $i$ den saken med at byggeleder (BL) var å anse som sekundærarbeidsgiver. Daglig leder og ansvarlig prosjektleder (AP) hos BL ble så holdt ansvarlige som virksomhetsledere etter aml. (1977) $\S 85$. Dette til tross for at arbeidstakerne - korpsmedlemmene - var medlemmer i et musikkorps som ivaretok flere av arbeidsgiverfunksjonene. 


\subsection{Adgangen til å holde flere virksomhetsledere ansvarlige samtidig}

Etter ordlyden i første punktum er arbeidsgiver enhver som har ansatt arbeidstaker. Virksomhetslederansvaret er imidlertid etter sin ordlyd begrenset til den som i arbeidsgivers sted leder virksomheten, jf. §§ 1-8 (2) (2) og 19-1. Språklig sett kan dette tale for at "virksomhetslederansvaret" bare kan anvendes overfor én av arbeidsgivers representanter.

Allerede i Rt. 1972 s. 1311 Pollo konkluderte imidlertid Høyesterett med at lovens ordlyd ikke var til hinder for at flere kunne holdes ansvarlige som ledere av virksomheten i arbeidsgivers sted. Den konkrete tvisten gjaldt en dødsulykke ved et $\mathrm{CO}_{2}$-anlegg, der både administrerende direktør og teknisk direktør ble ansett for å lede virksomheten i arbeidsgivers sted etter dagjeldende arbeidervernlov $\S 65$. Begge ble imidlertid frifunnet etter den aktsomhetsnorm retten anla - for den tekniske direktørens del under dissens (4-1). Retten tok ikke uttrykkelig stilling til om flere kunne holdes ansvarlig som virksomhetsledere. Forarbeidene til arbeidsmiljøloven av 1977 la til grunn at avgjørelsen ga uttrykk for gjeldende rett. ${ }^{52}$

Uten nærmere problematisering la også Høyesterett til grunn at det kunne være flere ansvarssubjekter innen samme virksomhet i Rt. 1988 s. 654, hvor både administrerende direktør og produksjonssjef (under dissens 3-2) ble dømt for overtredelse av arbeidsmiljøloven, og i Rt. 1990 s. 419 Asbest, hvor daglig leder og ansvarlig prosjektleder ble idømt ansvar sammen med byggefirmaet. Bestemmelsen i 1977-lovens $\S 85$ ble videreført i någjeldende aml. § 19-1, ${ }^{53}$ hvilket taler for at lovens ordlyd etter gjeldende rett ikke er til hinder for at flere kan anses som arbeidsgiverrepresentant i samme arbeidsforhold.

\subsection{Virksomhetslederansvarets rammer}

Både i forarbeidene til arbeidsmiljøloven av 1977 og i rettspraksis er det altså åpnet for at ansvar som «leder» etter aml. (2005) § 19-1 kan plasseres hos flere personer innen samme foretak. Spørsmålet er så hvor ansvaret kan plasseres, med andre ord hva som er rammene for virksomhetslederbegrepet. Lovens ordlyd består i denne sammenheng av flere elementer. For det første retter ansvaret seg til "virksomheten". ${ }^{54}$ For det andre må 129, jf. Ot.prp. nr. 3 (1975-76) s. 102. Jf. Ot.prp. nr. 49 (2004-2005) s. 343.

54 Se nærmere omtale av virksomhetsbegrepet under avsnitt 2.5 . 
ansvarssubjektet "lede" virksomheten. Det forutsettes med andre ord utøvelse av lederfunksjoner; en viss myndighet på arbeidsplassen. For det andre må vedkommende lede "i arbeidsgivers sted”. Ansvarssubjektet må med andre ord representere arbeidsgiver.

De nærmere rammer for hvem som kan holdes ansvarlige som virksomhetsledere må utledes av rettspraksis. I denne sammenheng er Pollo-avgjørelsen ${ }^{55}$ et naturlig utgangspunkt. Avgjørelsen er nærmere omtalt under punkt 3.62. Høyesterett la til grunn at både administrerende direktør og teknisk direktør kunne holdes ansvarlige som virksomhetsledere. De var «henholdsvis øverste administrative og tekniske leder» i sin bedrift, jf. gjengivelsen av byrettens redegjørelse for bedriftens organisasjon (s. 1315).

Høyesterett kom senere med klare uttalelser om rammene for virksomhetslederbegrepet i Rt. 1984 s. 773 Flesland. Under utvidelsen av Flesland flyplass førte en dårlig sikret takbjelke til at taket falt ned. Hendelsen resulterte i en dødsulykke, som rammet en av hovedentreprenørens ansatte. Spørsmålet var om hovedentreprenørens avdelingsingeniør og underentreprenørens driftsingeniør var ledere for virksomheten etter aml. (1977) $§ 85$. Høyesterett fant enstemmig at byrettens dom måtte oppheves som følge av mangelfulle domsgrunner.

Før Høyesterett vurderte anken over byrettens dom, knyttet førstvoterende noen generelle bemerkninger til hvordan virksomhetslederbegrepet etter $\S 85$ måtte forstås. Hvem som skulle anses som «leder for virksomheten i arbeidsgiverens sted» ville ofte være tvilsomt (s. 775). Som et utgangspunkt refererte han til forarbeidene, ${ }^{56} \mathrm{der} \operatorname{det}$ var forutsatt at ansvarsbestemmelsen bare skulle «omfatte den "øverste bedriftsledelse"» (s. 775). Etter førstvoterendes oppfatning var dette imidlertid ikke en klar grensedragning - for aksjeselskaper, som denne saken gjaldt, kunne ikke dette forstås som at ansvaret som "bedriftsleder" bare kunne påhvile administrerende direktør. På dette punkt var uttalelsen i tråd med Pollo-avgjørelsen.

Førstvoterende argumenterte i fortsettelsen for at:

«Hensett til blant annet bedriftens størrelse og struktur må bedriftslederbegrepet kunne omfatte andre som har lederfunksjoner. Den nærmere avgrensning må avhenge av hvor selvstendige fullmakter vedkommende har i tekniske og merkantile spørsmål».

Rt. 1972 s. 1311 Pollo.

$56 \quad$ Jf. Ot.prp. nr. 3 (1975-76) s. 102. 
Rammene for virksomhetslederbegrepet var etter førstvoterendes uttalelser relative. Ved fastsettelsen måtte det tas hensyn til forholdene ved den enkelte bedrift. Dette hadde støtte i forarbeidene, hvor det ble påpekt at fordelingen av ansvar måtte «bygge på den maktstruktur som [var] til stede» $\mathrm{i}$ den enkelte virksomhet. ${ }^{57}$ Som et grunnvilkår måtte vedkommende ha lederfunksjoner. Det sentrale vurderingsmoment i denne sammenheng var vedkommende leders selvstendighet, slik dette kom til uttrykk gjennom de fullmakter som hørte til stillingen. Høyesterett ga her anvisning på en konkret vurdering som åpnet for at ansvaret kunne plasseres andre steder enn hos "den øverste bedriftsledelsen". Retten viste så til Rt. 1982 s. 878 og Rt. 1983 s. 196 som prejudikater for en slik vurdering, hvor Høyesterett hadde lagt til grunn at lokale anleggsledere var å anse som virksomhetsledere. Ved å vise til avgjørelsene som prejudikater, tydeliggjorde Høyesterett i Flesland-saken at den ovennevnte uttalelsen i forarbeidene om «øverste bedriftsledelse» ikke kunne anses som en skranke; i hvert fall ikke for aksjeselskaper.

Allerede året etter, i Rt. 1985 s. 185 Kraftverk, tok Høyesterett på ny stilling til plasseringen av virksomhetsansvaret. Som følge av feilmanøvrering inntraff en arbeidsulykke på trallebanen ved et kraftverk, og en av kraftverkets ansatte ble drept. Daglig leder (A), som også var stasjonsleder, ble tiltalt som virksomhetsleder etter aml. (1977) $\S 85$, jf. $\S 4$. Han ble dømt i herredsretten og anket til Høyesterett, blant annet over lovanvendelsen i forbindelse med virksomhetslederbegrepet. Høyesterett forkastet anken på dette punkt (under dissens 4-1).

Ved vurderingen av om A var virksomhetsleder, uttalte førstvoterende på vegne av flertallet at:

«Avgjørelsen av dette spørsmål må etter min mening bero på en samlet bedømmelse av hvilken faktisk og rettslig myndighet domfelte hadde til selvstendig å treffe avgjørelser om virksomheten ved denne arbeidsplass» (s. 189; mine kursiveringer).

Uttalelsen kan leses som en presisering av den vurderingsnormen Høyesterett la til grunn i Flesland-avgjørelsen; begrepet "fullmakt" måtte tolkes til å omfatte både rettslig og faktisk myndighet.

Mindretallet dissenterte om forståelsen av virksomhetslederbegrepet. Annenvoterende påpekte innledningsvis at man stod $\mathrm{i}$ fare for å gå ut over bestemmelsens rekkevidde slik 
den var tilsiktet av lovgiver, dersom stasjonslederen ble holdt ansvarlig. For det første trakk annenvoterende fram at kun «den øverste bedriftsledelsen» kunne ilegges ansvar ifølge forarbeidene (s. 191). Han var også uenig i at de faktiske forhold skulle ha en like sentral betydning som førstvoterende la til grunn. Den formelle organiseringen av virksomheten måtte etter hans syn være avgjørende, blant annet på bakgrunn av betydningen for ansatte av om de ble holdt ansvarlige som arbeidsgiver eller arbeidstaker.

Førstvoterende var på sin side klar over uttalelsene i forarbeidene, men argumenterte med at:

«i et tilfelle som det foreliggende, hvor det er tale om en ansatt som utøver lederfunksjoner ved en selvstendig lokal enhet, er det etter min mening naturlig å pålegge arbeidsgiveransvar. Så vidt jeg kan se, har dette også støtte i praksis, jfr. særlig uttalelser i Rt-1984-773» (s. 190; mine kursiveringer).

I Flesland- og Kraftverk-avgjørelsen tok ikke Høyesterett uttrykkelig avstand fra uttalelsene i forarbeidene, om at virksomhetsbegrepet skal forbeholdes "den øverste bedriftsledelsen". Imidlertid ble det lagt til grunn at rammene for virksomhetslederansvaret er relative, avhengig av forholdene ved den enkelte bedrift. Dersom bedriften består av selvstendige lokale enheter, er det naturlig å anse den som utøver lederfunksjonene ved enheten som virksomhetsleder.

\subsection{Selve plasseringen - vurderingen og momentene}

Endelig må det undersøkes hvordan ansvaret plasseres. I denne sammenheng analyseres de momenter som Høyesterett har tillagt vekt ved vurderingen av hvem som kan holdes ansvarlig som virksomhetsleder.

I Flesland-saken, ${ }^{58}$ som er omtalt under punkt 3.63, la Høyesterett til grunn at spørsmålet om hvem som var virksomhetsleder måtte avgjøres etter en konkret vurdering av bedriften som sådan, og vedkommende leders rolle i den. Det skulle særlig legges vekt på «hvor selvstendige fullmakter vedkommende [hadde] i tekniske og merkantile spørsmål» (s. 775).

I de avgjørelsene førstvoterende viste til, så retten først nærmere på bedriften som sådan. I Rt. 1983 s. 196 ble det lagt til grunn at tiltalte, som øverste leder for selskapets aktiviteter «på et begrenset geografisk område», var ansvarlig som virksomhetsleder etter aml. (1977) § 85, jf. § 4, og ikke som arbeidstaker etter $\S 86$ (s. 201). I den konkrete saken drev selskapet virksomhet på flere forskjellige 
byggeplasser. I Rt. 1982 s. 878 ledet tiltalte byggearbeidet på en kornsilo, og ble av byretten etter en samlet vurdering ansett for å lede virksomheten i arbeidsgivers sted. Høyesterett la dette enstemmig til grunn (s. 880). For det andre måtte vedkommende leders rolle i selskapet vurderes. I Rt. 1983 s. 196 førte ingen i den øvrige ledelse daglig tilsyn med byggeplassen, og tiltalte hadde vidtgående og selvstendige fullmakter, både i økonomisk henseende og overfor arbeidstakerne (s. 200 flg.). I Rt. 1982 s. 878 hadde tiltalte ansvaret for, og oppsynet med, arbeidet. I tillegg hadde vedkommende den $\emptyset$ konomiske oversikten (s. 885).

I den senere Kraftverk-avgjørelsen, som er nærmere omtalt over under punkt 3.63, la Høyesteretts flertall til grunn at man måtte ta hensyn til både faktisk og rettslig myndighet for å avgjøre hvem som var virksomhetsleder. Mindretallet var uenig i at de faktiske funksjoner den ansatte utøvde skulle ha samme betydning som de formelle, og bemerket $\mathrm{i}$ denne sammenheng at «det i første rekke [måtte] være de oppgaver og funksjoner som rettslig sett»var tillagt stillingen man måtte se på (s. 192). Flertallet bemerket deretter at en «isolert bedømmelse av tilsettingsvilkår og instrukser» ikke ga noe klart grunnlag for å anse domfelte som virksomhetsleder (s. 189). Ifølge intern instruks var kontorlederen ved Driftsavdelingens driftskontor den ansvarlige stedlige driftslederen. Det var imidlertid på det rene at domfelte hadde utøvet sentrale lederfunksjoner, spesielt fordi vedkommende reelt sett stod for den daglige administrasjonen og ledelsen av kraftverket, samtidig som han hadde vide $\varnothing$ konomiske fullmakter. Førstvoterende fremhevet at praksis særlig måtte tillegges vekt der hvor «tilsettingsvilkår og instrukser ikke [ga] noe klart svar på hvilken myndighet som [lå] til stillingen» (s. 189). Høyesterett konkluderte etter dette med at domfelte var virksomhetsleder på bakgrunn av den faktiske arbeidsfordelingen ved kraftverket.

Den rettsoppfatningen som kom til uttrykk i Kraftverk-saken ble senere lagt til grunn i Rt. 1988 s. 692 Fasadeelement og Rt. 1990 s. 419 Asbest. I Fasadeelement-avgjørelsen ble en byggeplassingeniør, som var administrativ og teknisk leder av byggeplassen, med reell overordnet myndighet over driftens $\varnothing$ vrige ansatte, holdt ansvarlig som virksomhetsleder. I Asbest-saken ble to ansatte i byggelederselskapet holdt ansvarlige som virksomhetsledere. ${ }^{59}$ A var daglig leder og styreformann, og B var ansvarlig prosjektleder på byggeplassen. B opptrådte som mellommann mellom byggeleder og musikkorpset, med full instruksjonsmyndighet overfor korpset. A hadde full instruksjonsmyndighet over B, kontrollansvaret over bedriftens ansatte og kunnskap om at korpset var engasjert. 


\subsection{Sammenfatning}

Plasseringen av ansvar beror på en konkret helhetsvurdering av bedriftens størrelse og struktur, og vedkommende leders funksjoner. Lederfunksjonene vil da være de reelle og formelle fullmakter vedkommende har i tekniske og merkantile spørsmål. Styringsretten ser også her ut til å være et avgjørende faktor, særlig med hensyn til den faktiske muligheten til å gjennomføre nødvendige tiltak.

De avgjørelsene som er gjennomgått ovenfor viser at valget mellom å legge de formelle og de faktiske forhold til grunn kan få avgjørende betydning for plasseringen av ansvar. Selv om det kan være hensiktsmessig å plassere ansvaret hos den som faktisk har myndigheten på arbeidsplassen, fremfor der hvor den rettslig sett befinner seg, er ikke dette helt uproblematisk. Konsekvensen kan bli at ansvaret plasseres hos arbeidstakere som er pålagt ansvarsoppgaver ut over sine stillingsbeskrivelser. Ansatte et godt stykke ned i organisasjonen kan på denne måten bli holdt ansvarlig for at loven ikke overholdes, uten å være klar over at de står i en slik posisjon. Fordelen med å legge vekt på den faktiske myndigheten er imidlertid at man i større grad hindrer ansvarspulverisering, ettersom de som rettslig sett har fullmakten ikke nødvendigvis har en slik tilknytning til overtredelsen at de oppfyller kravet til skyld som er oppstilt i loven. Samtidig plasseres ansvaret hos den som i realiteten skulle sørget for at loven ble overholdt, uavhengig av de formelle forhold.

\subsection{Foretaksansvaret}

OIS- og Asbest-saken ${ }^{60}$ som ble nærmere gjennomgått under avsnittene 3.3 og 3.4 foran, gir eksempler på hvordan sammensatte arbeidsgiverforhold kan få betydning for plasseringen av foretaksansvaret. I OIS-saken opphevet Høyesterett byrettens dom, hvor OIS ble frifunnet for ansvar. Høyesterett anså OIS for å være sekundærarbeidsgiver for arbeidstakerne, ved siden av $\mathrm{M}$, som var arbeidstakernes primærarbeidsgivere etter hovedarbeidsavtalene. Dermed kunne OIS idømmes foretaksansvar etter aml. (1977) § 87. I Asbest-saken forkastet Høyesterett anken fra BL, som var domfelt for overtredelse av $\S 87$. BL ble ansett for å være arbeidsgiver for arbeidstakerne, til tross for at også MK utøvde arbeidsgiverfunksjoner overfor dem.

Foretaksansvaret etter aml. $\S 19-3$, jf. strl. $\S \S 48 \mathrm{a}$ og 48b, er i utgangspunktet vesensforskjellig fra arbeidsgiveransvaret, ved at vurderingstemaet er om arbeidsmiljølovens bestemmelser er overtrådt av noen som har handlet på vegne av 
foretaket. Det favner dermed videre enn et rent arbeidsgiveransvar. Rt. 1982 s. 645 Krankjennelsen er et godt eksempel på dette, hvor Høyesterett vurderte om oppdragsgiver skulle holdes ansvarlig som foretak etter aml.(1977) $\S 87$ for at en kran var brukt i strid med pålegg fra Arbeidstilsynet. Det var aldri et spørsmål om de som hadde benyttet seg av kranen var arbeidstakere hos oppdragsgiver, ettersom dette ikke var et krav etter bestemmelsen. Spørsmålet var om de hadde handlet på vegne av oppdragsgiveren. Ved at foretaket som er sekundærarbeidsgiver ilegges ansvar etter $\S 19-3$ kan man i enda større grad sikre at bestemmelsens formål; å hindre ansvarspulverisering, blir ivaretatt. ${ }^{61}$

61 Jf. Ot.prp. nr. 3 (1975-76) s. 89, punkt 5.3. Ettersom bestemmelsen er en videreføring fra arbeidsmiljøloven av 1977 har forarbeidene fortsatt aktualitet, se nærmere omtale under punkt 2.2. 


\section{Sammensatte arbeidsgiverforhold i relasjon til stillingsvernet}

\subsection{Innledende bemerkninger}

Arbeidsmiljølovens bestemmelser om stillingsvern i kapitlene 14-16 beskytter arbeidstaker mot vesentlige endringer $\mathrm{i}$ arbeidsforholdet, ${ }^{62}$ samt mot opphør ved oppsigelse eller avskjed. Bestemmelsene er av privatrettslig karakter og håndheves av arbeidsforholdets parter. Den overordnede problemstillingen i dette kapittelet er hvem som er ansvarlig som arbeidsgiver for å overholde bestemmelsene om arbeidstakers stillingsvern.

Ved inngåelsen av arbeidsavtalen etableres en styringsrett for arbeidsgiver. I kraft av styringsretten har arbeidsgiver «en makt vis à vis arbeidstageren til å treffe avgjørelser og fastsette bestemmelser med virkning for arbeidsforholdet og dets innhold». ${ }^{63}$ Dette innebærer blant annet at arbeidsgiveren ensidig kan gjøre visse endringer i arbeidsforholdet som er bindende for arbeidstaker. Men styringsretten er en restkompetanse. Arbeidsgivers utøvelse må forholde seg til de rammer som er følger av lov, arbeidsavtale og tariffavtale. Utøvelsen av styringsretten må derfor også holde seg innenfor de grenser som er trukket opp blant annet av arbeidsmiljølovens bestemmelser om stillingsvern. Samtidig må utøvelsen forholde seg til ulovfestede allmenne saklighetsnormer. ${ }^{64}$

Det er et nært samspill mellom styringsretten og stillingsvernsreglene. Følgelig er det naturlig å fremstille rettsavgjørelser om sammensatte arbeidsgiverforhold i relasjon til stillingsvernet i sammenheng med tilsvarende avgjørelser om styringsrettens grenser.

Arbeidstakers stillingsvern er som grunnleggende utgangspunkt knyttet til arbeidsgiverens "virksomhet", i betydningen foretaket (bedriften, den juridiske person). Det er dette det siktes til i aml. $\S 15-7(1)$ med «virksomhetens ... forhold». På samme måte er det foretaket - den juridiske personen - som i alminnelighet er rammen for omplasserings- og avveiningsvurderingene etter $\S 15-7(2)$. Men denne hovedregelen om hva som er "virksomheten", kan bli utfordret hvis det kan sies å foreligge et "sammensatt arbeidsgiverforhold". Dette kan tenkes i to hovedtyper av situasjoner: Der én arbeidsgiver - en

Se Storeng m.fl. (2011) s. 409 flg. om det forfatterne omtaler som "endringsoppsigelse" dersom endringen ligger utenfor det som kan gjennomføres i kraft av styringsretten.

Jf. Evju, «Arbeidsrett og styringsrett - et perspektiv», Arbeidsrett og arbeidsliv Bind 1 (2003), s. 11.

Jf. Storeng m.fl. (2011) s. 47. 
virksomhet - er knyttet til en eller flere andre juridiske personer, som for eksempel konsernforhold; og der én arbeidstaker selv, gjennom arbeidsavtale, har en tilknytning til mer enn én mulig arbeidsgiver.

\subsection{Kapittelets struktur}

Sammensatte arbeidsgiverforhold i relasjon til stillingsvernet er som nevnt av privatrettslig karakter, og forutsetter dermed et privatrettslig grunnlag. Vi kan skille mellom doble arbeidsavtaleforhold og lovbasert delte arbeidsgiverposisjoner.

Når det sammensatte arbeidsgiverforholdet oppstår i kraft av arbeidsavtalens bestemmelser, kan forholdet kalles et dobbelt arbeidsavtaleforhold $(D A F)$. Da er det som utgangspunkt arbeidsavtalen i "primærarbeidsforholdet" - hovedarbeidsavtalen (HAA) - som utgjør etableringsgrunnlaget for det sammensatte arbeidsforholdet. "Sekundærarbeidsforholdet" har som regel sitt grunnlag i HAA. I rettspraksis om denne formen for sammensatte arbeidsgiverforhold er Høyesteretts dommer i Rt. 1989 s. 231 ExLog og Rt. 2012 s. 983 Stena Drilling de mest sentrale.

Dersom det sammensatte arbeidsgiverforholdet ikke følger av arbeidsavtalen, vil det som oftest ha sitt grunnlag direkte i loven. Dette kan med en fellesbetegnelse kalles lovbasert delte arbeidsgiverposisjoner ( $L A P)$. Her kan det skilles mellom to hovedformer: En delt arbeidsgiverposisjon på bakgrunn av delte arbeidsgiverfunksjoner, og delt posisjon på bakgrunn av at flere rettssubjekter blir ansett for å utgjøre én og samme virksomhet. Wärtsilä-dommen ${ }^{65}$ er et eksempel på førstnevnte, jf. avsnitt 4.5. Kjennelsen i Rt. 1993 s. 345 Matherson-Selig kan sees som eksempel på det siste, jf. avsnitt 4.6.

I dette kapittelet analyseres høyesterettsavgjørelsene om DAF under avsnitt 4.3 og 4.4. Deretter følger analysene av høyesterettsavgjørelser om LAP under avsnittene 4.5 og 4.6. Under avsnitt 4.7 presenteres Rt. 1997 s. 623 PPD, hvor Høyesterett etter en konkret vurdering fant at arbeidsgiverforholdet ikke var sammensatt. Under avsnitt 4.8 presenteres enkelte avgjørelser fra underordnede domstoler hvor det ble vurdert om arbeidsforholdene bestod av LAP. Avslutningsvis presenteres noen slutninger fra rettspraksis om sammensatte arbeidsgiverforhold i relasjon til stillingsvernet. 


\subsection{Doble arbeidsavtaleforhold}

\subsection{Introduksjon}

Fra 1980-tallet har vi fire kjennelser og en dom, ${ }^{66}$ alle fra oljesektoren, hvor Høyesterett tok stilling til i hvilken grad utplassering av en arbeidstaker kan føre til at et sammensatt arbeidsgiverforhold blir ansett for å foreligge. Sakene gjaldt arbeidstakere som alle var ansatt $\mathrm{i}$ et utenlandsk selskap som inngikk $\mathrm{i}$ et internasjonalt konsern eller selskapsgruppe, og som hadde arbeidet en tid hos et av konsernselskapene som var etablert i Norge, enten som «expatriate» eller etter beordring i henhold til flytteplikt. Felles for arbeidsforholdene var at arbeidsavtalene med de utenlandske selskapene inneholdt bestemmelser om forholdet mellom arbeidstakerne og de norske selskapene under utplasseringen. Når arbeidsforholdene med de norske selskapene opphørte, og arbeidstakerne ble kalt tilbake, ble det reist spørsmål om arbeidstakerne ved utplasseringen var vernet av norsk arbeidsmiljølovgivning. Likhetstrekkene mellom både tvistenes faktum og dommernes rettslige vurderinger, samt Høyesteretts henvisning til de øvrige kjennelsene i Rt. 1989 s. 231 ExLog (s. 238), gjør det naturlig å behandle avgjørelsene samlet.

\subsection{ExLog-dommen}

Tvisten i ExLog-saken gjaldt berettigelsen av avskjedigelser som følge av ordrenekt. Tre ingeniører (AT) som var ansatt av ulike utenlandske selskaper innenfor Exploration Logging-gruppen, hadde en vid flytteplikt $i$ henhold til sine hovedarbeidsavtaler (HAA). Pollard og Lewis hadde inngått kontrakter med Exploration Logging (Services) Limited, og Hamp med Exploration Logging Overseas Inc. For enkelhets skyld omtaler jeg begge selskapene i det følgende som ExLog Utland (ELU), basert på at arbeidsforholdene mellom arbeidstakerne og selskapene var etablert gjennom identiske hovedarbeidsavtaler. Der det er nødvendig å skille mellom selskapene, bruker jeg deres fulle navn. Ingeniørene ble beordret til gruppens norske selskap i Bergen - Exploration Logging Norge A/S (ELN), og etter 17 måneder der, da det norske selskapet ikke lenger hadde bruk for deres tjenester, ble de beordret videre til gruppens selskap i Aberdeen, av ELU. De motsatte seg overflytting til Aberdeen og ble avskjediget. Arbeidstakerne stevnet ELN med påstand om at avskjedigelsene var ugyldige. ExLog. 
Ved kjennelse avviste byretten saken på bakgrunn av at arbeidstakerne var ansatt $\mathrm{i}$ et britisk selskap, og at tvisten ikke hørte under norsk jurisdiksjon. Det forelå avtale om utenlandsk rett og verneting i "primærarbeidsforholdet". Lagmannsretten omgjorde avvisningsavgjørelsen, og kjæremålet ble forkastet av Høyesteretts kjæremålsutvalg i Rt. 1985 s. 1319. Utvalget var enig i lagmannsrettens lovtolkning, som innebar at arbeidsmiljøloven bare kunne fravikes ved «kortvarige arbeidsforhold i Norge» (s. 1322). Utvalget kunne ikke prøve lagmannsrettens konklusjon om at det eksisterte et ansettelsesforhold mellom arbeidstakerne og ELN og at dette ikke var kortvarig. Arbeidsforholdet ble dermed ansett for å høre inn under norsk jurisdiksjon, underlagt norske preseptoriske rettsregler.

Da stillingsvernssaken deretter kom opp for Høyesterett i Rt. 1989 s. 231 ExLog, var det ikke lenger omtvistet at saken måtte avgjøres etter reglene i arbeidsmiljøloven, eller at arbeidstakerne hadde arbeidsforhold med ELN (s. 232). Høyesterett la til grunn at hovedarbeidsavtalen fortsatt bestod (s. 238). Selv om arbeidstakerne var vernet av arbeidsmiljøloven, innebar ikke det at flytteplikten etter HAA falt bort. Når arbeidstakerne motsatte seg påleggene om flytting, var dette brudd på hovedarbeidsavtalen som ga grunnlag for opphør av arbeidsforholdene etter arbeidsmiljølovens regler. Høyesterett fant at avskjedigelsen var gyldig for den ene ingeniøren (s. 239). De to andre hadde imidlertid ikke fått noe klart pålegg om å flytte, og kunne ikke avskjediges. De kunne imidlertid vært oppsagt (s. 240).

Ett av de sentrale spørsmålene som Høyesterett tok stilling til i sin avgjørelse, var om ingeniørene hadde flytteplikt i henhold til sine ansettelsesvilkår, og hvordan gjennomføringen av flytteplikten ville forholde seg til norsk preseptorisk lov. 


\subsection{Analyse og vurdering}

De sentrale partskonstellasjonene i ExLog-saken kan illustreres på følgende måte:

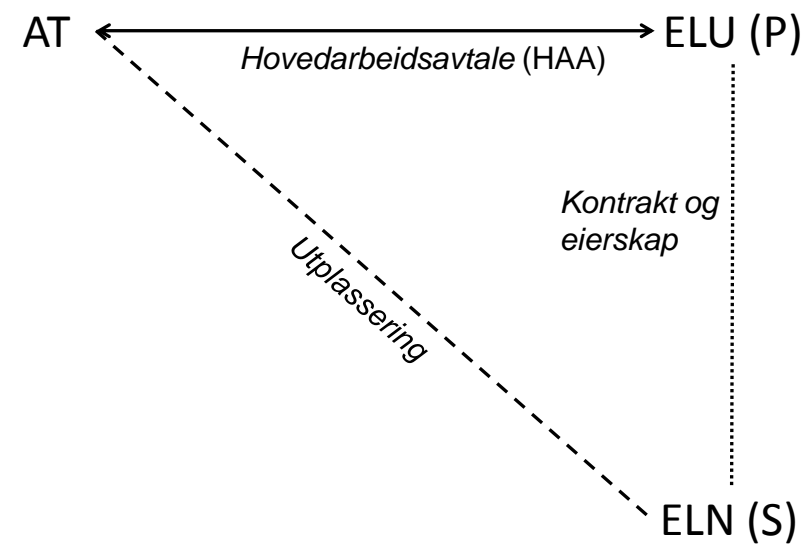

ELU var arbeidstakernes primærarbeidsgiver på bakgrunn av HAA. "Forretningsforholdet" mellom ELU og ELN hadde etter alt å dømme sin basis i eierskap og kontrakt. ${ }^{67}$ Aktørene på arbeidsgiversiden tilhørte samme internasjonale selskapsgruppe. Uten at det fremgår av premissene, legger jeg til grunn at det forelå en overensstemmelse innad i selskapsgruppen om at arbeidstakere kunne forflyttes internt. Mellom arbeidstakerne og ELN ble det lagt til grunn at det forelå arbeidsforhold som hadde sine grunnlag i hovedarbeidsavtalene, jf. ExLog-kjennelsen; ELN var arbeidstakernes sekundærarbeidsgiver.

I hovedarbeidsavtalene var det inntatt et punkt 3 om flytteplikt, hvor det var bestemt at arbeidstakeren til enhver tid kunne beordres av ELU til et annet selskap innen Exploration Logging-gruppen. Hovedarbeidsavtalens bestemmelser - sammen med eventuelle avtalte tilleggsendringer - skulle regulere den midlertidige utplasseringen ved det anviste selskapet som om dette var arbeidsgiver, uten at dette hadde noen betydning for det som var avtalt i "primærarbeidsforholdet", jf. Høyesteretts dom s. 237. Arbeidstakerne hevdet at det ved tiltredelsen i ELN «ble etablert nye og selvstendige kontraktsforhold» med ELN som arbeidsgiver. Begrunnelsen var blant annet at ELN utøvet «alle reelle arbeidsgiverfunksjoner, bortsett fra betaling av lønn». Ettersom ELN var arbeidsgiver, kunne ikke arbeidsforholdene bringes til opphør med mindre de ble oppsagt (s. 237). 
Høyesterett var ikke enig i at arbeidsforholdet med ELN innebar nye og selvstendige kontraktsforhold for arbeidstakerne. Førstvoterende bemerket innledningsvis at:

«Etter min mening ble det gjennom tiltredelsen i [ELN] etablert nettopp en slik situasjon som er regulert i hoved[arbeidsavtalens] punkt 3, hvoretter [avtalens] bestemmelse om flytteplikt fortsatt gjelder» (s. 237).

Som et utgangspunkt var arbeidstakerne bundet av flytteplikten som var avtalt med ELU, selv om de hadde arbeidsforhold med ELN. Hovedarbeidsavtalens bestemmelser gjaldt så lenge arbeidsforholdet som var etablert samstemte med det avtalen tok sikte på å regulere.

Førstvoterende stilte seg tvilende til om det kunne gis «et helt entydig svar» på hvem som var ingeniørenes arbeidsgiver, og bemerket i denne sammenheng at:

«Et slikt svar lar seg etter min mening ikke utlede av "Offer of employment", som ikke ble utferdiget med henblikk på kontraktsforholdet mellom [ELN og arbeidstakerne]. Det er imidlertid uten videre klart at [ELN] hadde viktige arbeidsgiverfunksjoner, herunder instruksjonsrett og ansvaret for overholdelse av norsk arbeidsmiljølovgivning, og iallfall i mange relasjoner må anses som arbeidsgiver. Men dette kan ikke være til hinder for at bestemmelsen om flytteplikt i hoved[arbeidsavtalens] punkt 3 må gjelde ... » (s. 237 flg.).

Tilbudet om ansettelse var ikke utferdiget med henblikk på kontraktsforholdet mellom arbeidstakerne og ELN, men med tanke på norske myndigheter. Den kunne derfor ikke tillegges vekt ved vurderingen av hvem som var ingeniørenes arbeidsgiver. Førstvoterende kommenterte imidlertid ikke betydningen av en eventuell avtale mellom arbeidstakerne og ELN. Det at ELN hadde viktige arbeidsgiverfunksjoner var derimot av betydning, og tilsa at selskapet «iallfall i mange relasjoner» måtte anses som arbeidsgiver (s. 238). Uttalelsen er for vag til å ta stilling til om retten anså ELN for å være arbeidsgiver i relasjon til stillingsvernsreglene. Høyesteretts konklusjon om at arbeidstakerne fortsatt var bundet av flytteplikten, innebar at retten ikke trengte å ta stilling til hvilke relasjoner ELN var arbeidsgiver i. Ettersom arbeidstakerne var forpliktet på avtalemessig grunnlag, hadde det ingen betydning om ELN var ansvarlig sammen med ELU for at arbeidsmiljølovens stillingsvernsregler ble overholdt. Førstvoterende påpekte avslutningsvis at ettersom arbeidstakerne hadde forpliktet seg til «ansettelse ved gruppen av Exploration Logging selskaper», jf. hovedansettelseskontrakten punkt 1 (s. 237), var det «mest nærliggende å anse [dem] som ansatt i gruppen» (s. 238). Gjennom hovedarbeidsavtalene hadde ingeniørene knyttet arbeidsforholdene sine til selve selskapsgruppen, og ikke bare motparten i arbeidsavtalen (ELU). Selv om ELU var ingeniørenes arbeidsgiver, var deres rettigheter og plikter knyttet til selskapsgruppen som helhet. På denne bakgrunn må 
uttalelsen forstås som at førstvoterende anså selskapsgruppen for å utgjøre arbeidsgivers virksomhet, se også om virksomhetsbegrepet under avsnitt 2.5.

Konsekvensen av at flytteplikten fortsatt gjaldt var at «de ansatte [kunne] beordres til flytting som [medførte] at tilknytningen til det norske selskap [opphørte], uten at det [var] nødvendig å gå veien om oppsigelse» (s. 238). Høyesterett fant støtte for sitt syn i tre avgjørelser av Høyesteretts kjæremålsutvalg, som blir nærmere omtalt i neste punkt. Det ble samtidig vist til at det var «et åpenbart behov for at det i slike internasjonalt pregede arbeidsforhold som det her [var] tale om, [måtte] kunne inngås avtale [om] internasjonal flytteplikt innenfor selskaper [i samme] selskapsgruppe» (s. 238). Hensynet til arbeidsmiljølovens anvendelse på arbeidsforhold på tvers av landegrensene tilsa her en innskrenkende fortolkning av arbeidsmiljølovens stillingsvernsregler. Loven var dermed ikke til hinder for et slikt avtalt opphør av arbeidsforholdet. Retten konkluderte på denne bakgrunn med at ingeniørene hadde gjort seg skyldig i ordrenekt ved å motsette seg flytting, og at det dermed var grunnlag for opphør av arbeidsforholdene.

\subsection{Relaterte kjennelser}

Til støtte for sitt syn viste førstvoterende til Kjæremålsutvalgets avgjørelser i Rt. 1987 s. 1412 Bowlin I og Rt. 1988 s. 476 Bowlin II mellom Bowlin og Conoco Inc., og NAD 1988 s. 696 Ancock (Høyesteretts kjæremålsutvalg). De to førstnevnte kjennelsene gjaldt samme tvist. Den amerikanske statsborgeren Bowlin var ansatt i det amerikanske selskapet Conoco Inc. (C) som «expatriate». Etter et arbeidsopphold hos datterselskapet i Norge, Conoco Norway Inc. $(\mathrm{CN})$, ble Bowlin beordret tilbake til USA av C. Han nektet å etterkomme beordringen og ble sagt opp på grunn av ordrenekt. Bowlin anla sak mot CN med påstand om at oppsigelsen var ugyldig. Byrettens avvisningskjennelse ble ikke tatt til følge av lagmannsretten, men Høyesteretts kjæremålsutvalg opphevet lagmannsrettens avgjørelse i Bowlin $\mathrm{I}$. Ved den nye behandlingen ble avvisningen stadfestet av lagmannsretten, og Kjæremålsutvalget forkastet kjæremålet i Bowlin II.

I Bowlin I kunne Kjæremålsutvalget ikke prøve lagmannsrettens konklusjon om at $\mathrm{CN}$ var Bowlins arbeidsgiver under arbeidsoppholdet i Norge, men anså det for å være en mangel ved lagmannsrettens begrunnelse at den ikke inneholdt noen «vurdering av hvilken betydning Bowlins arbeidsforhold til selskapet i U.S.A. [hadde] for hans arbeidsforhold til det norske selskap» (s. 1415). Det var også en mangel at lagmannsretten ikke hadde tatt standpunkt til om overføringsbeslutningen, og CNs effektuering av denne, kunne anses som oppsigelse eller avskjed etter arbeidsmiljøloven. Verken Bowlin eller CN bestred at Bowlin måtte akseptere overføring etter sin arbeidskontrakt med C. Spørsmålet var dermed i hvilken grad flytteplikten kunne gjøres gjeldende i arbeidsforholdet mellom CN og Bowlin. 
Utvalget bemerket at med mindre en særskilt arbeidskontrakt var inngått med $\mathrm{CN}$, talte gode grunner for «at Bowlin fortsatt var undergitt de vilkår som [fulgte] av hans arbeidskontrakt med selskapet i U.S.A., eventuelt med de modifikasjoner som var avtalt i forbindelse med at han ble overført til tjeneste i Norge» (s. 1415). Dersom dette ble lagt til grunn, ville Bowlin «være kontraktsrettslig forpliktet til å akseptere overføring til arbeid i et annet land» selv om dette innebar at arbeidsforholdet til CN opphørte (s. 1415). I Bowlin II tok utvalget stilling til lagmannsrettens vurdering av at Bowlin hadde en utstrakt internasjonal flytteplikt etter ansettelseskontrakten med primærarbeidsgiveren, som ikke opphørte til tross for at han knyttet et arbeidsforhold til det norske datterselskapet. På denne bakgrunn hadde lagmannsretten kommet fram til at pålegg om gjennomføring av flytteplikten «i et slikt internasjonalt arbeidsforhold» ikke kunne anses som «oppsigelse i arbeidsmiljølovens forstand», selv om det innebar at tilknytningen til det norske datterselskapet opphørte. Kjæremålsutvalget sluttet seg til denne lovtolkningen (s. 480).

Tvistens partskonstellasjoner kan illustreres slik:

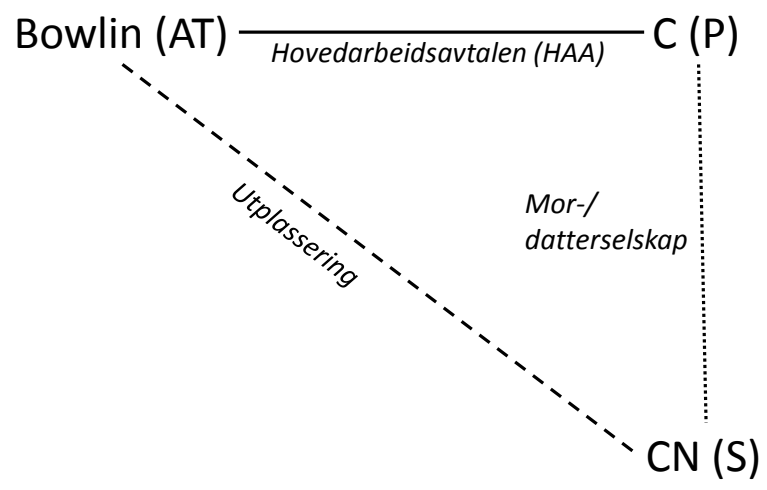

I dette bildet kan Kjæremålsutvalgets standpunkt karakteriseres som at utvalget vurderte arbeidsforholdet til CN som sekundært til arbeidsforholdet med C. Selv om Bowlin hadde arbeidsforhold til to selskaper, var begge i utgangspunktet regulert av hovedarbeidsavtalen. Bowlin var dermed fortsatt kontraktsrettslig forpliktet til å oppfylle flytteplikten etter hovedarbeidsavtalen. Cs beslutninger i arbeidsforholdet med Bowlin fikk dermed direkte betydning for det forholdet som var etablert mellom Bowlin og $\mathrm{CN}$, uten at $\mathrm{CN}$ var part $\mathrm{i}$ hovedarbeidsavtalen. I premissene påpekte Kjæremålsutvalget at Bowlin var undergitt det som var avtalt $\mathrm{i}$ arbeidskontrakten med $\mathrm{C}$, «eventuelt med de modifikasjoner som var avtalt i forbindelse med at han ble overført» til CN (s. 480). Det fremgår ikke av utvalgets vurdering om det da tok sikte på modifikasjoner som måtte være avtalt med $\mathrm{C}$ eller $\mathrm{CN}$. Dersom noe var avtalt direkte med $\mathrm{CN}$, kunne det i så fall ha vært vurdert som en «særskilt 
arbeidskontrakt», slik at Bowlin på selvstendig grunnlag var forpliktet overfor $\mathrm{CN}$. Bowlin anførte at en gjennomføring av flytteplikten uten at stillingsvernsreglene var oppfylt, ville innebære diskriminering av utenlandske arbeidstakere. Til dette bemerket Kjæremålsutvalget at arbeidsforholdets art var avgjørende, ikke arbeidstakerens nasjonalitet. Det er ikke helt klart hva utvalget la i "arbeidsforholdets art". Retten kan ha siktet til "sekundærarbeidsforholdets" karakter av å være et aksessorisk og midlertidig rettsforhold; ved opphøret av dette rettsforholdet ville ansettelsesforholdet med primærarbeidsgiveren fortsatt bestå, slik at arbeidstakeren hadde en stilling å vende tilbake til. En annen mulig forståelse av utsagnet er at det ble lagt vekt på at forholdet var av internasjonal karakter, jf. tilsvarende uttalelser av Høyesterett i ExLog-dommen.

I ExLog-dommen viste Høyesterett som nevnt også til Kjæremålsutvalgets avgjørelse i NAD 1988 s. 696 Ancock. Tvisten verserte i domstolene samtidig som Bowlin-saken, og hadde mange likhetstrekk med denne. Ancock ble ansatt som «expatriate» i Esso Exploration and Production U.K. (EEP), «på vegne av» Esso Exploration Norway Inc. ${ }^{68}$ (EEN), som var en avdeling i Esso-konsernet. ${ }^{69}$ Ancock ble deretter utplassert i EEN, som senere ble omdannet til et selvstendig datterselskap i Esso-systemet. Etter en tid avviklet EEN ordningen med «expatriate»-vilkår, og Ancock ble sagt opp da EEP ikke hadde noen stilling å tilby. Denne oppsigelsen ble imidlertid trukket tilbake, og Ancock ble tilbudt en stilling hos EEN på norske vilkår, som var mindre fordelaktige enn de tidligere «expatriate»-vilkårene. Ancock protesterte, og han ble dermed kalt tilbake til EEP. Han etterkom ikke tilbakekallingen, og etter en stund ble han nektet inngang på arbeidsplassen $\mathrm{i}$ Norge. Han betraktet dette som en oppsigelse, noe EEN bestred. Han stevnet så EEN med påstand om at han var ansatt hos dette selskapet, og ba i den sammenheng om kjennelse på at han kunne stå i «expatriate»-stillingen hos EEN så lenge saken varte. Verken byretten eller lagmannsretten ga ham medhold i dette. Høyesteretts kjæremålsutvalg sluttet seg til lagmannsrettens avgjørelse ut fra at lagmannsretten hadde det samme rettslige utgangspunkt som i Bowlin-kjennelsen. Partskonstellasjonen i Ancock-saken kan illustreres slik:

Lagmannsretten la til grunn at stillingen som «expatriate» ville si at Ancock var utplassert fra EEP til EEN.

69 Det er lagmannsretten som benyttet seg av uttrykket «på vegne » i sine premisser. Det er nærliggende å forstå dette på bakgrunn av at EEN på det tidspunktet var en avdeling av et utenlandsk selskap (etter aksjeloven av 1957 kapittel 16), ikke et eget aksjeselskap. 


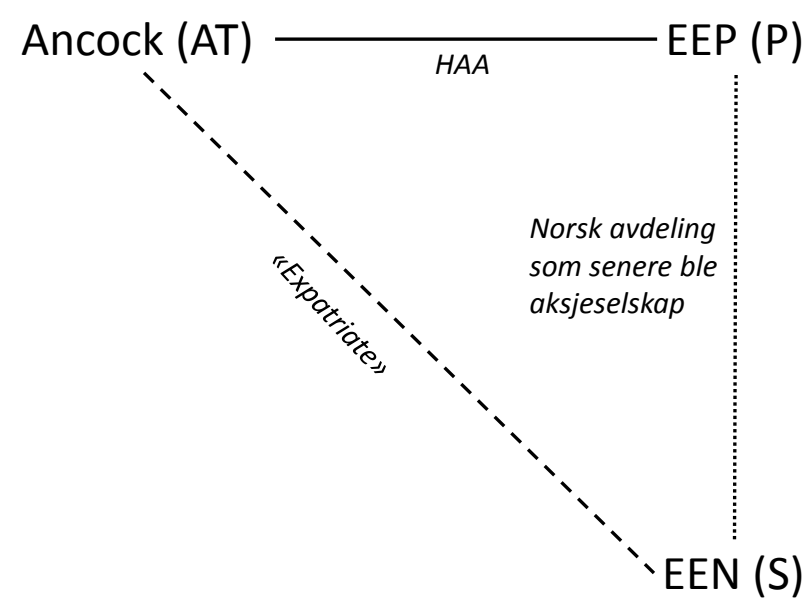

Lagmannsretten fant at Ancock var ansatt «med [EEP] som sin primærarbeidsgiver og at han midlertidig var utplassert i Norge». EEP var å anse som primærarbeidsgiver, men det var «ikke til hinder for at han samtidig hadde et arbeidstakerforhold til [EEN]». Lagmannsretten viste til Kjæremålsutvalgets første kjennelse i Bowlin-saken, ${ }^{70}$ som da stod foran sin siste behandling av Utvalget. Omorganiseringen av EEN fra avdeling til aksjeselskap medførte etter Lagmannsrettens oppfatning ingen endringer i Ancocks ansettelsesforhold, blant annet på bakgrunn av at det ikke ble utferdiget noen nye ansettelseskontrakter og at Ancock fortsatte i stillingen på «expatriate»-vilkår. Tilbakebeordringen til England var følgelig gyldig i henhold til hovedarbeidsavtalen. Høyesteretts kjæremålsutvalg ga sin støtte til dette og viste også til den siste av Bowlin-kjennelsene. ${ }^{71}$ Etter utvalgets syn var det altså ikke noe problem at de to arbeidsforholdene eksisterte samtidig. Den selskapsmessige omstruktureringen ble følgelig ikke ansett for å påvirke arbeidsforholdet.

\subsection{Sammenfatning og slutninger}

Høyesterett innledet i Rt. 1989 s. 231 ExLog med at hovedarbeidsavtalen mellom ingeniørene og utenlandske ELU fortsatt måtte gjelde, til tross for at ingeniørene hadde tiltrådt stillinger i norske ELN. Bakgrunnen var at avtalen tok sikte på å regulere nettopp en slik situasjon. Som et utgangspunkt var ingeniørene kontraktsrettslig bundet av flytteplikten. Spørsmålet var imidlertid om det var grunnlag for å anse arbeidstakerne som ubundet av hovedarbeidsavtalens bestemmelser som følge av omstendighetene for $\varnothing v$ rig; arbeidsforholdet mellom ingeniørene og ELN var i seg selv ikke tilstrekkelig. Høyesterett

71 Rt. 1988 s. 476 Bowlin II. 
vurderte først om det forelå noen avtale mellom ingeniørene og ELN som kunne gi grunnlag for å fravike hovedarbeidsavtalen. Et slikt avtalegrunnlag ble ikke funnet. Deretter kommenterte retten det reelle forholdet mellom ELN og ingeniørene. Til tross for at ELN utøvde flere arbeidsgiverfunksjoner, og i flere relasjoner var å anse som arbeidsgiver, ga heller ikke dette grunnlag for å fravike hovedarbeidsavtalene. Høyesterett konkluderte så med at ingeniørene fortsatt var bundet av hovedarbeidsavtalenes bestemmelser om flytteplikt. Spørsmålet var deretter om arbeidsmiljøloven var til hinder for å gjøre flytteplikten gjeldende. Med henvisning til Bowlin-kjennelsene og Ancockkjennelsen, samt behovet for å kunne avtale en effektiv internasjonal flytteplikt, konkluderte retten med at gjennomføringen av flytteplikten ikke innebar oppsigelser etter arbeidsmiljøloven.

I Rt. 1987 s. 1412 Bowlin I la Høyesteretts kjæremålsutvalg til grunn at Bowlin i utgangspunktet var underlagt bestemmelsene i hovedarbeidsavtalen med utenlandske $\mathrm{C}$, med de modifikasjoner som var avtalt i forbindelse med overføringen til norske CN. Selv i arbeidsforholdet med $\mathrm{CN}$ var dermed Bowlin «kontraktsrettslig forpliktet til å akseptere overføring til arbeid i et annet land». Kjæremålsutvalget forutsatte imidlertid at det ikke var inngått noen «særskilt arbeidskontrakt» mellom Bowlin og CN (s. 1415). I Rt. 1988 s. 476 Bowlin II kom saken opp for Kjæremålsutvalget igjen. Kjæremålsutvalget refererte den tidligere kjennelsen, og tilføyde at gjennomføringen av flytteplikten ikke var å anse som en oppsigelse etter arbeidsmiljøloven «i et slikt internasjonalt preget arbeidsforhold» (s. 480).

Kjæremålsutvalget fulgte opp kjennelsene fra Bowlin-saken i NAD 1988 s. 696 Ancock, og forkastet anken over lagmannsrettens lovanvendelse på bakgrunn av at lagmannsretten hadde samme rettslige utgangspunkt som utvalget i Bowlin I, og at utvalget forkastet kjæremålet i Bowlin II.

I de ovennevnte avgjørelsene hadde arbeidstakerne sine "primærarbeidsforhold" med utenlandske selskaper; henholdsvis ELU, C og EEP. Etter terminologien jeg anvender var disse selskapene arbeidstakernes primærarbeidsgivere $(\mathrm{P})$. I henhold til bestemmelser i hovedarbeidsavtalene (HAA) de hadde inngått med $\mathrm{P}$, ble arbeidstakerne utplassert til norske selskaper (i Ancocks tilfelle norsk avdeling); henholdsvis ELN, CN og EEN. Ved utplasseringen etablerte arbeidstakerne "sekundærarbeidsforhold" med de norske enhetene; 
enhetene ble etter gjeldende terminologi sekundærarbeidsgivere $(S){ }^{72}$ De sammensatte arbeidsgiverforholdene var etablert på avtalemessig grunnlag; de var doble arbeidsavtaleforhold.

Det går en klar linje fra kjennelsene i Bowlin-saken og Ancock-saken til ExLog-dommen, som bekreftes av Høyesteretts henvisning til kjennelsene i premissene. Arbeidstakerne var i utgangspunktet kontraktsrettslig forpliktet til å overholde bestemmelsene i hovedarbeidsavtalene. Dette gjaldt selv om det ble etablert "sekundærarbeidsforhold", så lenge etableringen skjedde i kraft av de allerede eksisterende avtalene. Dersom det ble inngått særskilte avtaler med sekundærarbeidsgiver, ble det åpnet for at dette kunne ha betydning for hovedarbeidsavtalens rekkevidde. Imidlertid så verken Kjæremålsutvalget eller Høyesterett grunn til å gå nærmere inn på dette. I ExLog-dommen fremhevet også Høyesterett at det norske selskapet hadde flere sentrale arbeidsgiverfunksjoner, et moment som ikke ble kommentert av Kjæremålsutvalget i Bowlin-saken og Ancock-kjennelsen. Dette forholdet endret imidlertid ikke Høyesteretts standpunkt om at bestemmelsene i hovedarbeidsavtalene fortsatt måtte gjelde. Standpunktet innebar at det som var bestemt i "primærarbeidsforholdet" også gjaldt i "sekundærarbeidsforholdet", selv om kun arbeidstakerne og P var parter i det forholdet, og ikke S.

Spørsmålet var så om arbeidsmiljøloven hindret primærarbeidsgiverne fra å gjøre flytteplikten gjeldende, ved at lovens vilkår måtte være oppfylt for at "sekundærarbeidsforholdene" skulle opphøre. I Bowlin II støttet Høyesteretts kjæremålsutvalg lagmannsretten $\mathrm{i}$ at gjennomføring av flytteplikten «i et slikt internasjonalt preget arbeidsforhold» ikke kunne anses som en oppsigelse i lovens forstand (s. 480). Dette synet sluttet Utvalget seg til i Ancock-kjennelsen, og det ble også lagt til grunn i ExLogdommen. I både Bowlin II og ExLog-dommen ble det imidlertid fremhevet at dette gjaldt «internasjonalt pregede arbeidsforhold». ${ }^{73}$ Det er uklart hvorvidt retten åpnet for at resultatet ville bli det samme i "nasjonale" arbeidsforhold, eller om arbeidsforholdenes internasjonale karakter var en forutsetning for rettens konklusjoner. til et aksjeselskap.

73 Jf. Rt. 1988 s. 476 Bowlin II (s. 480) og Rt. 1989 s. 231 ExLog (s. 238). 


\subsection{Rt. 2012 s. 983 Stena Drilling}

\subsection{Saken}

Tvisten i Rt. 2012 s. 983 Stena Drilling gjaldt seconderte arbeidstakeres rettslige stilling ved overdragelse av den virksomheten de var secondert til. ${ }^{74}$ Arbeidstakerne var i realiteten utplassert fra et utenlandsk selskap til et norsk selskap innen samme konsern, men saken skiller seg likevel på flere områder fra ExLog-saken. I Stena Drilling var det tale om en virksomhetsoverdragelse etter arbeidsmiljøloven kapittel 16. Dessuten var det inngått en tariffavtale som hadde anvendelse for de aktuelle arbeidsforholdene. Disse forholdene hadde til dels avgjørende betydning for rettens vurderinger og konklusjoner.

Saken gjaldt spørsmål om hvorvidt fire arbeidstakere hadde krav på å få arbeidsforholdene sine overført til en «erverver» etter reglene om virksomhetsoverdragelse i aml. kap. 16. Boreriggen Stena Dee ble solgt til Songa Offshore ASA (SO) av et selskap i Stenakonsernet. Ved salget endret riggen navn til Songa Dee. Samtidig inngikk SO avtale om utleie av riggen til et annet selskap innen Stena-konsernet. To andre selskaper innen Stenakonsernet, Stena Drilling Pte Ltd. (SDPL) og Stena Drilling AS (SD), sørget for bemanningen av riggen. SD bestod av fast ansatte. De ansatte i SDPL var utplassert til SD på secondmentavtaler. Formelt var arbeidstakerne fortsatt ansatt i SDPL, men SD utøvde alle arbeidsgiverfunksjoner. De fire arbeidstakerne saken angikk var alle utplassert fra SDPL til SD. Da utleieavtalen for riggen opphørte, ble Songa Dee tilbakeført til eieren, SO. Samtidig ble arbeidstakerne oppfordret til å søke stillinger i Songa Services AS (SS), som stod for bemanningen av riggen etter tilbakeføringen. De fire arbeidstakerne søkte om stillinger, men ble ikke ansatt. De ble informert om at secondmentene opphørte ved tilbakeføringen, og at de ble tilbakekalt til sine stillinger i SDPL. Arbeidstakerne reiste etter dette søksmål mot SD og SS «med krav om at de [hadde] rett til å fortsette sine arbeidsforhold på Songa Dee, i samme stilling og på samme vilkår som de hadde hos [SD]», med krav om ugyldighet og gjeninntredelse (avsnitt 9).

Det første hovedspørsmålet Høyesterett tok stilling til var om tilbakeføringen av en rigg til eierselskapet innebar en «virksomhetsoverdragelse». Høyesterett fant at vilkårene for der primærarbeidsgiver "leier ut" arbeidstakeren til en annen arbeidsgiver (en vert). Normalt vil verten utbetale lønn til primærarbeidsgiver, og kan også måtte betale en leieavgift. Tanken er at den seconderte arbeidstakeren fortsetter å være ansatt hos primærarbeidsgiveren i utleieperioden, og at vedkommende returnerer til primærarbeidsgiveren når perioden er slutt (se dommens avsnitt 98). 
virksomhetsoverdragelse etter aml. kap. 16 var oppfylt. De som var arbeidstakere på riggen på overføringstidspunktet hadde dermed krav på å følge med ved overføringen (avsnitt 94).

Det andre hovedspørsmålet var om arbeidstakerne som var utplassert etter secondmentavtaler hadde slik tilknytning til riggen, at arbeidsforholdene gikk over til eierselskapet som erverver av virksomheten. Høyesterett konkluderte her med at arbeidstakernes rettigheter og plikter etter arbeidsforholdet med driftsselskapet var blitt overført. Arbeidstakerne ble også tilkjent erstatning basert på ulovfestede regler om ansvar i kontraktsforhold, ettersom de uberettiget var blitt avvist som arbeidstakere. SD og SS ble begge holdt ansvarlige for utbetalingen av erstatningsbeløpet.

Partskonstellasjonen i saken og problemstillingen i det andre hovedspørsmålet kan illustreres slik:

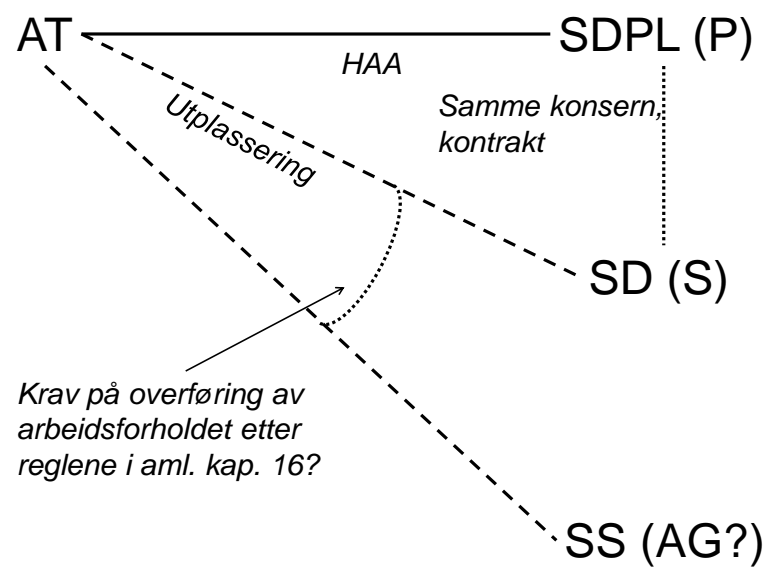

Arbeidstakerne hadde inngått hovedarbeidsavtaler (HAA) med SDPL, som følgelig var deres primærarbeidsgiver $(\mathrm{P})$. Etter sine hovedarbeidsavtaler kunne arbeidstakerne bli utplassert til andre selskaper gjennom secondmentavtaler. SDPL og SD tilhørte begge Stena-konsernet. SDPL stod for bemanningen av riggene som ble drevet av SD. Arbeidstakerne var utstasjonert til SD gjennom secondmentavtaler mellom SD og SDPL. SD opptrådte dermed som vertsforetak for arbeidstakerne i utplasseringsperioden. SS var Songa-gruppens bemanningsselskap, og det som da skulle ansette mannskap til riggen når den nå skulle drives i Songa-gruppens regi.

\subsection{Analyse og vurdering}

Høyesterett presiserte innledningsvis at arbeidstakernes krav om ansettelse i SS måtte bero på om de hadde en «ansettelsesmessig tilknytning» til riggen før overføringen (avsnitt 96). $\mathrm{SD}$ og SS anførte to grunner for at arbeidstakerne ikke hadde en slik tilknytning: For det 
første var de ikke "ansatt" hos SD på overføringstidspunktet, men kun utstasjonert etter secondmentavtaler. For det andre hadde de under enhver omstendighet flytteplikt.

Høyesterett la til grunn at arbeidstakerne hadde bakenforliggende "primærarbeidsforhold" med SDPL. Spørsmålet var så om AT på bakgrunn av secondmentene likevel hadde et arbeidsforhold til SD som ga grunnlag for overføring til SS etter aml. § 16-2(1), (avsnitt 102). Som grunnlag for at utplasserte arbeidstakere kunne ha rettigheter ved virksomhetsoverdragelse viste Høyesterett til EU-domstolens avgjørelse i Albron-saken. ${ }^{75}$ Etter Høyesteretts oppfatning kunne ikke adgangen til å følge med i en virksomhetsoverdragelse være begrenset til arbeidstakere som var utplassert på permanent basis. Også andre ikke-kontraktuelle arbeidsforhold måtte etter omstendighetene kunne gi grunnlag for ansettelse hos erververen.

I avsnitt (103) oppstilte Høyesterett noen generelle retningslinjer for hvordan de konkrete secondmentene skulle vurderes. Retten støttet seg da til en artikkel av en skotsk jurist, Barry Nichol, og inntok et lengre referat direkte i premissene (avsnitt 102). ${ }^{76}$ Med referanse til artikkelen fremholdt førstvoterende at primærarbeidsgiver måtte «opprettholde det vesentlige av arbeidsgiverfunksjonene» for å beholde status som arbeidsgiver. ${ }^{77}$ Han uttalte dermed at:

«Jo mer det reelle forholdet mellom verten og den " seconderte " [sic.] har karakter av et ordinært ansettelsesforhold, jo lettere vil dette bli lagt til grunn, i alle fall på den måten at den " seconderte" [sic.] kan gjøre gjeldende rettigheter som tilkommer ordinært ansatte hos verten» (avsnitt 103).

Ettersom SD, og ikke SDPL, utøvde alle arbeidsgiverfunksjonene overfor arbeidstakerne i løpet av de femårige secondmentene, og arbeidstakerne hadde «lønns- og arbeidsvilkår på linje med arbeidstakere på riggen som var direkte ansatt i Stena Drilling», måtte arbeidstakerne anses som «ansatte i Stena Drilling AS ... for så vidt gjelder rettigheter som følger av virksomhetsoverdragelse» (avsnitt 104). Etter dette konkluderte retten med at

Jf. C-242/09 Albron.

76 For nærmere omtale av rettskildebruken og avgjørelsen for $\varnothing v$ rig se Evju, «Virksomhetsoverdragelse, arbeidsavtalebegrep og common law - Rt. 2012 s. 983», Nytt $i$ privatretten 2012, $n r .3$, s. 1-4.

77 Høyesterett benytter seg her av uttrykket «ordinær arbeidsgiver» fremfor primærarbeidsgiver. 
arbeidstakerne i utgangspunktet hadde rett til ansettelse i SS, på bakgrunn av at de hadde en «ansettelsesmessig tilknytning til riggen» (avsnitt 105).

Spørsmålet var imidlertid om arbeidsgiversidens andre innsigelse kunne føre frem; at arbeidstakerne hadde en flytteplikt som hindret dem i å gjøre retten til ansettelse i SS gjeldende. Etter secondmentavtalene var arbeidstakerne utplassert på ubestemt tid, fram til secondmentene ble avsluttet av enten SD eller SDPL. Etter sin ordlyd ga dette SD og SDPL en ubegrenset rett til å tilbakekalle secondmentene, slik at arbeidstakerne ble tilbakeført til SDPL. Klausulen måtte imidlertid leses på bakgrunn av tillegg til en tariffavtale som SDPL var bundet av. I tillegget var det fastsatt at forflytting «elsewhere than the rig on which the employee finds himself cannot be imposed except with good reason, when such reason has been found reasonable by the local union» (avsnitt 106). Etter rettens oppfatning måtte secondmentavtalene leses på bakgrunn av tariffavtalen mellom SDPL og NOPEF, uavhengig av om det var SD eller SDPL som ville avslutte secondmentene. SD var dermed bundet av tariffavtalens bestemmelser uten å være part eller medlem i en organisasjon som var part. Retten kom imidlertid ikke tilbake til kravet om «good reason». ${ }^{78}$

Det endelige spørsmålet med hensyn til flytteplikten var om arbeidstakerne var forpliktet til å rette seg etter tilbakekallingen, slik at de mistet retten til ansettelse i SS etter aml. § 16-2. Høyesterett fremhevet at secondmentene ikke ble avsluttet som følge av utløpet av en tidsbegrensning, men utelukkende på grunn av virksomhetsoverdragelsen. Etter aml. § 16-4 kunne ikke virksomhetsoverdragelsen i seg selv gi grunnlag for oppsigelse. AT hadde imidlertid ikke et formelt arbeidsforhold med SD. Følgelig kunne ikke tilbakekallingen anses som en oppsigelse etter rettens vurdering. Førstvoterende konkluderte med at

«[d]e samme hensyn som ligger bak $§ 16-4$, gjør seg imidlertid tilsvarende gjeldende ved tilbakekall av secondment. Jeg må derfor konkludere med at tilbakekallingen av ankemotpartene ikke har fratatt dem retten til ansettelse i Songa Services AS» (avsnitt 110).

Selv om førstvoterende ikke uttrykkelig la det til grunn, er det nærliggende å forstå uttalelsen som at aml.§16-4 måtte gis analogisk anvendelse «ved tilbakekall av secondment». Etter førstvoterendes analogislutning var ikke tilbakekallingen av arbeidstakerne gyldig, til tross for at tilbakekallingen ikke innebar en oppsigelse. 


\subsection{Diskusjon}

Dommen i Rt. 2012 s. 983 Stena Drilling inneholder noen uklarheter som fortjener en nærmere vurdering.

Første spørsmål er om Høyesterett med "ansettelsesmessig tilknytning" viste til en kvalifikasjonsregel, som forutsatte en sterkere forbindelse mellom arbeidstakerne og SD enn det som er normalt $\mathrm{i}$ et arbeidsforhold mellom en utplassert arbeidstaker og vertsforetaket. $^{79}$ Etter aml. $§ 16-2(1)$ overføres «[t]idligere arbeidsgivers rettigheter og plikter som følger av arbeidsavtale eller arbeidsforhold» til den nye arbeidsgiver ved virksomhetsoverdragelse. Etter lovens ordlyd er vilkåret at det foreligger et «arbeidsforhold», jf. § 16-2(1). Høyesterett kommenterte ikke lovens ordlyd. I stedet la retten til grunn at spørsmålet var om arbeidstakerne hadde «et arbeidsforhold til Stena Drilling AS som kan gi grunnlag for overføring til Songa Services AS etter arbeidsmiljøloven § 16-2 første ledd» (avsnitt 99; mine kursiveringer). Uttalelsen gir inntrykk av at arbeidsforholdet mellom arbeidstakerne og SD måtte være av en slik art at det ga grunnlag for overføring til SS. Denne slutningen underbygges av at retten formulerte spørsmålet som om det forelå en ansettelsesmessig tilknytning. Høyesteretts rettslige utgangspunkt innebar dermed en innskrenkende tolkning av begrepet «arbeidsforhold» $\mathrm{i}$ $\S 16-2 .^{80}$

Neste spørsmål er hvilke forhold som talte for at arbeidsforholdet mellom arbeidstakerne og SD kvalifiserte til en "ansettelsesmessig tilknytning". Arbeidstakernes arbeidsforhold med SD var ikke nedfelt i noen arbeidsavtale med SD. «Det formelle ansettelsesforholdet» hadde de til SDPL (avsnitt 99). For å ta stilling til om arbeidsforholdet var av en slik art at aml. § 16-2(1) kom til anvendelse, utdypet Høyesterett det rettslige utgangspunktet nærmere. Under henvisning til EU-domstolens avgjørelse i Albron-saken ${ }^{81}$ la retten til grunn at "ikke-kontraktuelle arbeidsforhold" i flere tilfeller kunne gi grunnlag for ansettelse hos erververen ved virksomhetsoverdragelse. Deretter kom førstvoterende med en generell bemerkning:

Sml. Sekundærarbeidsforholdene som er omtalt foran under punkt 4.35.

I ExLog-saken og Bowlin-saken, nærmere omtalt under avsnitt 4.3, ble det lagt til grunn at arbeidsforhold ble etablert mellom arbeidstaker og vertsforetak ved utplassering.

C-242/09 Albron. 
«Skal den opprinnelige arbeidsgiver beholde statusen som arbeidsgiver, må denne opprettholde det vesentlige av arbeidsgiverfunksjonene. Jo mer det reelle forholdet mellom verten og den " seconderte" [sic.] har karakter av et ordinært ansettelsesforhold, jo lettere vil dette bli lagt til grunn, i alle fall på den måten at den " seconderte " [sic.] kan gjøre gjeldende rettigheter som tilkommer ordinært ansatte hos verten» (avsnitt 103).

Førstvoterende bemerket innledningsvis at primærarbeidsgivers (i uttalelsen "opprinnelig arbeidsgiver") status «som arbeidsgiver» kunne falle bort dersom denne ikke opprettholdt «det vesentlige av arbeidsgiverfunksjonene» (avsnitt 103). Det er uklart hva Høyesterett la i dette. Status som arbeidsgiver bortfaller ikke automatisk. Både primærarbeidsgiver og arbeidstaker vil være kontraktuelt forpliktet etter arbeidsavtalens bestemmelser. Dersom statusen som arbeidsgiver skulle falle bort ved at vedkommende ikke opprettholder "det vesentlige av arbeidsgiverfunksjonene", åpner det for at arbeidsgiver vil kunne omgå arbeidsmiljølovens bestemmelser om stillingsvern ved for eksempel å utplassere arbeidstaker i en annen bedrift for en periode.

Etter min vurdering er dermed førstvoterendes formulering lite heldig isolert sett, ved at den kan gi rom for slutninger som åpner for en slik uheldig praksis. Dersom uttalelsen sees i lys av konteksten, gir den derimot anvisning på en annen slutning.

Den aktuelle problemstillingen gjaldt arbeidstakernes rettigheter ved virksomhetsoverdragelse etter arbeidsmiljølovens kapittel 16. Som lagt til grunn innledningsvis under avsnitt 4.1 relaterer disse rettighetene seg til arbeidstakernes stillingsvern etter loven. Problemstillingen faller derfor inn under arbeidsgivers ansvar for arbeidstakernes stillingsvern. Spørsmålet Høyesterett tok stilling til var dermed om SD var arbeidsgiver $i$ relasjon til stillingsvernet. Dersom dette ble besvart bekreftende, ville arbeidstakerne kunne gjøre gjeldende rettigheter etter arbeidsmiljølovens kapittel 16 overfor SD.

Spørsmålet om SD var arbeidsgiver måtte avgjøres ut fra forbindelsen mellom SD og de seconderte arbeidstakerne. Jo mer «det reelle forholdet» mellom SD og arbeidstakerne lignet et helt ordinært ansettelsesforhold, jo større grunn var det til at arbeidstakerne skulle ha de samme rettighetene overfor SD som de fast ansatte i selskapet (avsnitt 103). Etter en konkret vurdering av hvilke arbeidsgiverfunksjoner som SD utøvet overfor arbeidstakerne; i dette tilfellet alle, konkluderte Høyesterett med at arbeidstakerne hadde de samme rettighetene overfor SD som de som var fast ansatt der. Høyesteretts konklusjon innebar på dette punkt at SD ble ansett for å være arbeidsgiver i relasjon til stillingsvernet.

Som nevnt under punkt 4.42 kan Høyesteretts premisser tyde på at retten forlot tariffavtalens forutsetning om «good reason» uten nærmere kommentar (avsnitt 106). Tariffavtalen kan imidlertid ha vært et moment i rettens vurdering av om analogislutninger 
fra aml. § 16-4 skulle gis anvendelse på tilbakekallingen av arbeidstakerne. Vilkåret i tariffavtalen om at en «good reason» måtte foreligge for at arbeidstakerne kunne forflyttes fra riggen, medførte en begrensning i adgangen til å gjøre flytteplikten gjeldende. Begrensningen hadde flere likhetstrekk med arbeidsmiljølovens krav om saklig grunn ved

oppsigelse, jf. aml. § 15-7. Høyesterett bemerket at tilbakekallingen ikke kunne anses som en oppsigelse. Retten konkluderte imidlertid med at hensynene som lå bak § 16-4 gjorde seg tilsvarende gjeldende ved tilbakekallingen av secondment. Dette taler for at retten vurderte tilbakekallingen i lys av tariffavtalens bestemmelser som et opphør av arbeidsforholdet tilsvarende en oppsigelse. Et slikt resonnement taler for at arbeidstakerne fortjente samme vern mot tilbakekalling som de ville hatt mot en oppsigelse dersom de var fast ansatt i SD.

\subsection{Sammenfatning og slutninger}

Selv om arbeidstakerne formelt var ansatt i SDPL, ble de ansett for å ha en "ansettelsesmessig tilknytning” til SD. Bakgrunnen var at SD i flere år hadde utøvd alle arbeidsgiverfunksjonene. De hadde derfor i utgangspunktet rett til ansettelse i SS etter reglene i aml. $\S 16-2(1)$. Arbeidstakerne ble imidlertid tilbakekalt til SDPL i henhold til den flytteplikten som var inntatt i secondmentavtalene. Tilbakekallingen innebar at arbeidstakernes arbeidsforhold til SD opphørte, og at de mistet sin rett til å gjøre rettighetene etter § 16-2(1) gjeldende. Høyesterett vurderte om tilbakekallingen var bindende for de seconderte arbeidstakerne, og fant at de var ubundet. Selv om tilbakekallingsadgangen ifølge secondmentene var ubegrenset, måtte den leses på bakgrunn av en tariffavtale som forutsatte saklig grunn for at arbeidstakerne skulle kunne flyttes fra riggen. Etter aml. $\S 16-4$ kan ikke arbeidstaker sies opp på grunn av virksomhetsoverdragelse. Høyesterett la til grunn at tilbakekallingen ikke innebar en oppsigelse, og at arbeidstakerne ikke kunne utlede noe vern direkte av bestemmelsen i $\S 16-4$. Imidlertid gjorde de samme hensyn seg gjeldende ved tilbakekallingen som bestemmelsen tok sikte på å verne. På denne bakgrunn konkluderte Høyesterett med at arbeidstakerne ikke var forpliktet til å rette seg etter tilbakekallingen.

Sett i lys av min overordnede problemstilling kan Stena Drilling-dommen leses som en avgjørelse om plasseringen av arbeidsgiverplikter i sammensatte arbeidsgiverforhold, og forholdet mellom avtalte ordninger og preseptoriske lovbestemmelser. Det var på det rene at arbeidstakerne hadde arbeidsforhold til SDPL, som var deres primærarbeidsgiver, og Stena Drilling, hvor de var utplassert. Jeg anser SD som sekundærarbeidsgiveren deres i secondmentene. Arbeidstakerne hadde dermed sammensatte arbeidsgiverforhold med selskaper innen Stena-konsernet. 
Høyesterett vurderte "arbeidsforholdets karakter" for å ta stilling til om de seconderte arbeidstakerne kunne gjøre gjeldende de samme rettighetene overfor vertsforetaket SD som fast ansatte, og dermed få arbeidsforholdet overført ved virksomhetsoverdragelsen. Etter førstvoterendes uttalelser var målet for vurderingen var å undersøke hvorvidt de seconderte arbeidstakernes forbindelse med SD reelt sett hadde karakter av å være et "ordinært ansettelsesforhold". På bakgrunn av at SD utøvde alle arbeidsgiverfunksjonene, konkluderte Høyesterett med at arbeidstakerne hadde en slik tilknytning til SD at de måtte anses som «ansatte» (avsnitt 104).

I punkt 4.43 argumenterte jeg for at spørsmålet som i realiteten ble stilt, var om SD var de seconderte arbeidstakernes arbeidsgiver i relasjon til stillingsvernsreglene. For å ta avgjøre spørsmålet la retten til grunn en funksjonell tilnaerming; den vurderte hvorvidt SDs utøvelse av arbeidsgiverfunksjoner overfor de seconderte arbeidstakerne tilsa et slikt ansvar for selskapet. De reelle forhold, og da særlig utøvelsen av arbeidsgiverfunksjoner, var avgjørende for om SD skulle holdes ansvarlig for at arbeidsmiljølovens stillingsvernsbestemmelser ble overholdt.

Konklusjonen om at SD var arbeidsgiver i relasjon til stillingsvernet innebar endringer for det sammensatte arbeidsgiverforholdet som fulgte av hovedarbeidsavtalen. SD ble ansvarlig i større grad enn det som fulgte av secondmentavtalene med SDPL. Høyesterett konklusjon innebar imidlertid ikke at hovedarbeidsavtalens bestemmelser ble fraveket. I rettens premisser ble det ikke gitt uttrykk for at hovedarbeidsavtalen regulerte SDs ansvar for de seconderte arbeidstakernes stillingsvern. Rettens konklusjon innebar dermed et supplement til hovedarbeidsavtalene.

Høyesterett konkluderte med at SD og SDPL ikke kunne tilbakeføre til seconderte arbeidstakerne til SDPL når dette ble begrunnet med virksomhetsoverdragelsen. Det er nødvendig å se nærmere på rettens begrunnelse i denne sammenheng for å kartlegge hvilke forhold som lå til grunn for rettens konklusjon. Etter aml. § 16-4 er arbeidstakere vernet mot å bli oppsagt som følge av virksomhetsoverdragelse. Høyesterett la imidlertid til grunn at tilbakekallingen ikke innebar noen oppsigelse av arbeidstakerne, så bestemmelsen kom ikke til anvendelse. Etter rettens oppfatning var tilbakekallingen ikke bindende for arbeidstakerne fordi «de samme hensyn som ligger bak $\S 16-4$, gjør seg ... tilsvarende gjeldende ved tilbakekall av secondment» (avsnitt 110). Spørsmålet er derfor hva som lå i denne uttalelsen. Som et utgangspunkt kan det legges til grunn at Høyesterett anvendte $\S 16-4$ analogisk. Selv om det konkrete saksforholdet falt utenfor bestemmelsens ordlyd, så måtte arbeidstakerne være vernet mot tilbakekalling på lik linje med at de fast ansatte i SD 
var vernet mot oppsigelse ved virksomhetsoverdragelsen. Tilsynelatende var Høyesterett av den oppfatning at tilbakekallingen av secondmentene måtte sidestilles med oppsigelse.

Selv om Høyesterett hadde konkludert med at tilbakekallingen ikke innebar noen oppsigelse, måtte de to altså sidestilles. Selve tilbakekallingsadgangen var etter secondmentene ubegrenset, men den måtte sees i lys av tariffavtalen som SDPL hadde inngått med de seconderte arbeidstakernes fagorganisasjon. I tariffavtalen var det fastsatt at arbeidstakerne ikke kunne flyttes fra riggen med mindre dette var saklig begrunnet; et krav om «good reason» (avsnitt 106). Det er nærliggende å anta at retten anså dette kravet for å tilsvare saklighetskravet som gjelder ved oppsigelse av arbeidstakere, og at retten på denne bakgrunn kom til at analogislutninger fra $\S 16-4$ måtte få anvendelse.

Gjennomgangen over viser at analogislutninger fra preseptoriske lovbestemmelser ga grunnlag for å fravike hovedarbeidsavtalens bestemmelser. Avgjørelsen er dermed et eksempel på at det som er bestemt i doble arbeidsavtaleforhold kan bli fraveket på grunnlag av lovbestemmelser.

Retten vurderte det slik at de samme hensyn som lå bak § 16-4 gjorde seg «tilsvarende gjeldende ved tilbakekall av secondment». Det er usikkert om retten viste til secondment generelt, eller de konkrete secondmentene den hadde vurdert. I sin gjennomgang av secondment som avtaleform hadde beskrev Høyesterett dette som et rammeverk, hvor det kunne forekomme flere individuelle versjoner. I den konkrete saken var det kun secondmentene i SD som ble vurdert. De vurderte secondmentene var også mer omfattende enn det som var normalt for slike ordninger, jf. beskrivelsen av secondment $\mathrm{i}$ dommens avsnitt (98). På denne bakgrunn er det nærliggende å anta at retten viste til de aktuelle secondmentene, og ikke secondment generelt sett. Avgjørelsen kan derfor neppe tas til inntekt for at utplasserte arbeidstakere generelt er vernet etter analogislutninger fra $\S 16-4$.

\subsection{Rt. 1990 s. 1126 Wärtsilä}

\subsection{Saken}

I Rt. 1990 s. 1126 Wärtsilä fant Høyesterett at et sammensatt arbeidsgiverforhold var oppstått på bakgrunn av en helhetsvurdering av hovedarbeidsavtalen og de reelle forhold. Et morselskap ble ansett for å være arbeidsgiver sammen med et datterselskap med grunnlag i aml. (1977) § 4.

Saken for Høyesterett gjaldt i korte trekk gyldigheten av oppsigelsen av en administrerende direktør og krav om erstatning og oppreisning som følge av oppsigelsen. Thord Läckström ble i 1986 sagt opp etter drøye åtte år som administrerende direktør og daglig leder i Wärtsilä Diesel A/S (heretter datterselskapet), som var et heleid norsk datterselskap av det 
finske konsernet $\mathrm{Oy}$ Wärtsilä $\mathrm{AB}$ (heretter morselskapet). Før han kom til Norge hadde Läckström arbeidet i knappe syv år med dieselmotorer hos morselskapet ved Vasafabrikken. I 1977 fikk han i oppdrag å starte opp den norske virksomheten, og drev denne inntil virksomhetsomlegging medførte at han ble sagt opp. Han saksøkte både morselskapet og datterselskapet for ugyldig oppsigelse, og fikk medhold i byretten, men selskapene ble frifunnet i lagmannsretten under dissens. Høyesterett fant at oppsigelsen var gyldig, men at det skulle svares erstatning for tapt lønn fram til Høyesteretts dom forelå, da arbeidstakeren hadde rett til å stå i stillingen fram til dette tidspunkt. Det norske selskapet og morselskapet i Finland ble holdt solidarisk ansvarlige som arbeidsgivere for erstatningsutbetalingen. Det var dissens om erstatningens størrelse (3-2).

Partsforholdene og problemstillingen kan illustreres slik:

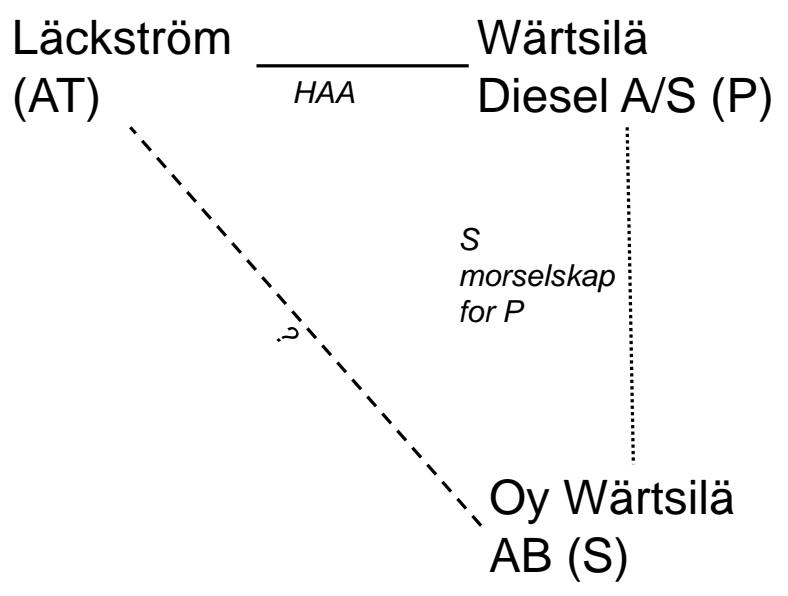

Datterselskapet var arbeidsgiver i henhold til arbeidsavtalen (HAA) med Läckström; datterselskapet var primærarbeidsgiver $(\mathrm{P})$. Oy Wärtsilä $\mathrm{AB}$ var heleiende morselskap for Wärtsilä Diesel AS. "Forretningsforholdet" bestod dermed av eierskap i konsernforhold. Det forelå ingen særskilt avtale mellom Läckström og morselskapet. Spørsmålet var om morselskapet var arbeidsgiver, og på hvilket grunnlag.

\subsection{Analyse og vurdering}

Første hovedspørsmål for Høyesterett var hvem som var Läckströms arbeidsgiver etter arbeidsmiljøloven. Etter en gjennomgang av detaljene rundt Läckströms forhold til morselskapet og datterselskapet, konstaterte retten raskt at Läckströms ansettelse i datterselskapet var «klart å anse som et arbeidsforhold etter arbeidsmiljøloven» (s. 1132). Datterselskapet hadde følgelig arbeidsgiveransvar etter denne lov. Omstendighetene omkring ansettelsen, som at ansettelsesavtalen ble inngått mellom Läckström og morselskapet, og at 
arbeidsforholdet var nærmere avtalt gjennom forutgående brevveksling mellom morselskapets ledelse og Vasafabrikken, ble i denne sammenheng ikke tillagt vekt.

Høyesterett nøyde seg imidlertid ikke med å konstatere at datterselskapet var Läckströms arbeidsgiver. Førstvoterende var

«ut fra en samlet vurdering av forholdet mellom datterselskap og morselskap og de plikter og rettigheter Thord Läckström hadde overfor morselskapet under sitt midlertidige opphold i Oslo, kommet til at også morselskapet måtte anses som arbeidsgiver etter arbeidsmiljøloven § 4» (S. 1132).

Morselskapet ble følgelig ansett for å være arbeidsgiver sammen med datterselskapet. Dette innebar at Läckström hadde to arbeidsgivere i den samme stillingen. Morselskapets posisjon som arbeidsgiver fulgte verken av særskilt avtale mellom Läckström og morselskapet, eller uttrykkelig av hovedarbeidsavtalen mellom Läckström og datterselskapet. Høyesterett anså morselskapet for å være arbeidsgiver etter aml. (1977) § 4.

Selv om morselskapet tidligere hadde vært Läckströms arbeidsgiver, så var det arbeidsforholdet blitt overført til datterselskapet. Morselskapet hadde dermed ikke lenger i formell forstand «tilsatt» Läckström, jf. § 4. Spørsmålet er i denne sammenheng hvilke rettsfakta som lå til grunn for at morselskapet ble ansett for å være Läckströms arbeidsgiver etter loven; en konklusjon som innebar at Läckström hadde et sammensatt arbeidsgiverforhold med de to selskapene.

I premissene la Høyesterett til grunn en samlet vurdering av to forhold; "forretningsforholdet" mellom morselskapet og datterselskapet, og de plikter og rettigheter Läckström hadde overfor morselskapet. Forholdene kan med fordel belyses adskilt, til tross for at de ble vurdert i sammenheng. Høyesterett hadde egne bemerkninger til hvordan forholdene ble vurdert. Samtidig sluttet retten seg i det vesentlige til «de synspunkter lagmannsrettens mindretall har gitt uttrykk for» (s. 1132). Premissene til lagmannsrettens mindretall hadde dermed direkte relevans for Høyesteretts resultat.

"Forretningsforholdet" ble i liten grad omtalt av Høyesterett. Lagmannsrettens mindretall gikk derimot grundigere til verks. ${ }^{82}$ Spørsmålet ble formulert som om et morselskap kunne identifiseres med sitt datterselskap i relasjon til arbeidsmiljøloven. Utgangspunktet var at 
slik identifikasjon ikke fant sted, men det ble antatt å kunne fravikes i særlige tilfeller. ${ }^{83}$ Mindretallet fant etter en gjennomgang av de faktiske omstendigheter at morselskapet hadde en dominerende stilling overfor datterselskapet. Det ble lagt avgjørende vekt på at datterselskapet var heleid av morselskapet, og at til tross for å være et eget rettssubjekt, så var datterselskapet reelt sett en del av morselskapets virksomhet. Grunnlaget for å anse datterselskapet for å være en del av morselskapets virksomhet bestod av særlig to elementer. For det første ble Läckströms ansettelse i datterselskapet først formalisert ved avtale «nærmere tre år» etter at han begynte der som administrerende direktør. ${ }^{84}$ Läckström inngikk da hovedarbeidsavtale med morselskapet, som representerte datterselskapet. For det andre hadde morselskapet full kontroll «i enhver henseende», noe som blant annet ble tydeliggjort ved at datterselskapet ikke hadde noe selvstendig økonomisk liv. På bakgrunn av at Høyesterett i det vesentlige sluttet seg til de synspunkter lagmannsrettens mindretall hadde gitt uttrykk for, er det nærliggende å anta at mindretallets vurdering av "forretningsforholdet” også lå til grunn for Høyesteretts vurdering.

Høyesterett vurderte forholdet mellom Läckström og morselskapet på bakgrunn av brevveksling mellom ledelsen på Läckströms tidligere arbeidsplass ved Vasafabrikken og morselskapets ledelse, samt hovedarbeidsavtalen mellom Läckström og datterselskapet, som ble inngått mellom Läckström og morselskapet.

For det første ble det lagt vekt på at morselskapet etter hovedarbeidsavtalen hadde «avgjørende innflytelse» over Läckströms lønns- og pensjonsforhold, selv om disse forhold egentlig hørte inn under datterselskapets myndighet. Normalt vil et morselskap kunne ha innflytelse på daglig leders lønns- og pensjonsrettigheter i kraft av sitt eierskap, både gjennom generalforsamlingen, jf. aksjeloven $^{85} \S \S 5-1(1)$, og ved å utnevne styrerepresentanter, jf. § 6-3(1). ${ }^{86}$ Gjennom bestemmelsene i hovedarbeidsavtalen ble arbeidsgivers forhandlingsrett med hensyn til lønns- og pensjonsforhold overført fra datterselskapet til morselskapet. Morselskapets indirekte påvirkningsmuligheter ble dermed kommentar, side 538 flg., og M. Andenæs’ innlegg på Nordisk Juristmøte 1984 (forhandlingene ved det 30. nordiske juristmøte del II side $186 \mathrm{flg}$.). Jf. LE-1987-663

$85 \quad$ Lov 13. juni $1997 \mathrm{nr} .44$ om aksjeselskaper (asl.)

86 Se tilsvarende bestemmelser i dagjeldende lov 4. juni 1976 nr. 59 om aksjeselskaper $\S \S 8-1(2)$ og 9-1(1). 
omgjort til direkte forhandlingsmyndighet. Ordningen medførte at den formelle selskapsstrukturen fikk en mer perifer rolle. Videre var Läckström gjennom hovedarbeidsavtalen forpliktet til å «følge de direktiver som til enhver tid ble gitt av morselskapets ledelse» (s. 1132), en forpliktelse arbeidstaker som regel har overfor sitt arbeidsgiverselskap. Eierne av selskapet er i utgangspunktet henvist til å instruere gjennom generalforsamlingsvedtak. Ved å forplikte Läckström til å følge de direktiver som til enhver tid ble gitt av morselskapet, skar hovedarbeidsavtalen på ny gjennom de formelle selskapsstrukturene, og ga grunnlag for en mer direkte forbindelseslinje mellom morselskapets ledelse og datterselskapets daglige drift. Som en konsekvens av dette ville manglende oppfyllelse av morselskapets direktiver fra Läckströms side innebære et brudd på Läckströms individuelle forpliktelser i arbeidsforholdet. For Läckströms del bestemte hovedarbeidsavtalen også at han hadde rett til å gjeninntre i morselskapets tjeneste når ansettelsen i datterselskapet var slutt.

Etter bestemmelsene i hovedarbeidsavtalen hadde altså Läckström og morselskapet vidtgående rettigheter og forpliktelser overfor hverandre. Høyesterett la også vekt på at morselskapet indirekte hadde oppsigelsesretten i Läckströms arbeidsforhold, og at morselskapets ledelse sendte den første uoffisielle oppsigelsen - det kom en endelig oppsigelse et drøyt år senere fra datterselskapet. ${ }^{87}$ I utgangspunktet er det «det organ som har tilsettingsmyndighet» som har myndighet til å si opp daglig leder. ${ }^{88}$ Etter aksjeloven (1976) $\S 8-4$, jf. tilsvarende i asl. $\S 6-2$, tillå denne myndigheten styret, men det kunne vedtektsfestes at myndigheten skulle tilligge generalforsamlingen. Etter min mening er det nærliggende å anta at retten vurderte oppsigelsen fra morselskapet i sammenheng med morselskapets sterke deltakelse i ansettelsesprosessen, og ut fra dette kom til at morselskapet i realiteten utøvde sentrale arbeidsgiverfunksjoner som tilsetting og oppsigelse av Läckström. Dette talte i favør av å anse morselskapet for å være arbeidsgiver for Läckström etter aml. (1977) $§ 4$.

Avslutningsvis bemerket førstvoterende at man vurderte Läckströms arbeidsforhold under det «midlertidige opphold[et]» han hadde i datterselskapet (s. 1132). Dette kan selvfølgelig ha vært en konstatering av fakta uten betydning for vurderingen. På den annen side er det ikke sikkert at førstvoterende ville konkludert med at morselskapet var arbeidsgiver dersom Läckströms ansettelse i Norge var permanent. Dersom Läckströms arbeidsforhold med

Se LE-1987-663. 
morselskapet var blitt endelig avsluttet åtte år tidligere, uten at han hadde noen gjeninntredelsesrett, ville trolig terskelen for å anse morselskapet for å være arbeidsgiver vært enda høyere. I denne sammenheng er det verdt å merke seg at ExLog-avgjørelsen, som førstvoterende fant støtte i, nettopp gjaldt et midlertidig arbeidsopphold i et norsk selskap (s. 1133).

Høyesterett konkluderte med at morselskapet måtte «anses som arbeidsgiver etter arbeidsmiljøloven $\S 4 i$ den forbindelse som her er aktuell» (s. 1132; min kursivering). Det ligger implisitt i uttalelsen at arbeidsgiverbegrepet i denne sammenheng ikke ble ansett for å være absolutt. Morselskapet kunne være arbeidsgiver i den aktuelle forbindelse, uten å nødvendigvis være det $\mathrm{i}$ en annen. Wärtsilä-saken gjaldt primært daglig leders oppsigelsesvern, jf. aml. (1977) $§ 60$ nr. 2 og 3. Førstvoterende hadde følgelig tatt stilling til hvem som var arbeidsgiver i forbindelse med stillingsvernsreglene.

Saken gjaldt imidlertid også Läckströms krav om erstatning for tapt lфnn fram til oppsigelsestidspunktet, til tross for at retten kom til at oppsigelsen var gyldig. Etter aml. (1977) § 61 nr. 4 hadde Läckström krav på å fortsette i sin stilling fram til saken var rettskraftig avgjort. Han ble som nevnt ovenfor tilkjent erstatning for tapt lønn fram til Høyesteretts dom, og både morselskapet og datterselskapet ble holdt ansvarlige for utbetalingen (s. 1135). Arbeidsgiversiden hadde ikke gjort gjeldende krav om fratredelseskjennelse etter $\S 61 \mathrm{nr} .4$, og retten fant heller ikke grunn til å fravike lovens ordning ut fra rimelighetsbetraktninger. Kravet om erstatning for tapt lønn kan imidlertid vanskelig sees som relatert til stillingsvernet som sådan. Det at begge selskapene ble holdt ansvarlige for utbetalingen av arbeidsvederlaget taler til fordel for at morselskapet også ble ansett for å være arbeidsgiver forbindelse med utbetaling av arbeidsvederlag.

Etter å ha konkludert med at både morselskap og datterselskap var arbeidsgivere for Läckström, bemerket førstvoterende at han

«ikke kan se at det etter arbeidsmiljøloven er noe til hinder for å anse et datterselskap og et morselskap for å ha felles arbeidsgiveransvar hvor arbeidsgiverfunksjonene er delt mellom begge selskaper slik det her er tilfelle, jfr. til sammenligning Rt-1989-231» (s. 1132 flg.)

Forutsatt at arbeidsgiverfunksjonene var delt mellom selskapene, kunne et morselskap og et datterselskap etter førstvoterendes oppfatning ha felles arbeidsgiveransvar. Det var med andre ord ikke nødvendig å plassere ansvaret hos en av dem. Både morselskapet og datterselskapet utøvde arbeidsgiverfunksjoner i relasjon til Läckströms stillingsvern og krav på lønn, og begge ble dermed holdt solidarisk ansvarlig for disse forhold. 


\subsection{Sammenfatning og slutninger}

I Wärtsilä-saken fant Høyesterett at både datterselskap og morselskap var arbeidsgivere for samme arbeidstaker. Läckström var etter sin hovedarbeidsavtale ansatt i datterselskapet; datterselskapet var Läckströms primærarbeidsgiver (P).

Det forelå ingen særskilt avtale mellom morselskapet og Läckström som ga grunnlag for å anse morselskapet som arbeidsgiver for Läckström. Posisjonen som arbeidsgiver var heller ikke direkte avtalt i hovedarbeidsavtalen mellom Läckström og datterselskapet. Arbeidsforholdet var dermed ikke et dobbelt arbeidsavtaleforhold. Høyesterett kom til at morselskapet var «arbeidsgiver» sammen med datterselskapet etter aml. (1977) § 4; morselskapet var Läckströms sekundærarbeidsgiver (S). Datterselskapet og morselskapet hadde med dette en lovbasert delt arbeidsgiverposisjon.

Høyesterett baserte sin konklusjon om at morselskapet var arbeidsgiver på en samlet vurdering av "forretningsforholdet" og forholdet mellom Läckström og morselskapet. Dette var en konkret helhetsvurdering hvor det ble lagt vekt på flere momenter. Sentralt $\mathrm{i}$ vurderingen av "forretningsforholdet" stod morselskapets dominerende stilling over datterselskapet. Høyesterett sluttet seg til lagmannsrettens mindretall, som la til grunn at datterselskapet reelt sett var en del av morselskapets virksomhet. Ved vurderingen av forholdet mellom morselskapet og Läckström la Høyesterett til grunn det som fulgte av hovedarbeidsavtalen. Etter denne avtalen hadde morselskapet og Läckström vidtgående rettigheter og plikter overfor hverandre. Blant annet var Läckström gjennom hovedarbeidsavtalen forpliktet til å følge morselskapets direktiver og forholde seg til de lønns- og pensjonsbetingelser selskapet fastsatte. Samtidig hadde Läckström etter avtalen rett til å gjeninntre i morselskapets tjeneste etter at ansettelsen i datterselskapet var avsluttet. Ut over disse forhold hadde morselskapet også arbeidsgiverfunksjoner overfor Läckström: Läckströms hovedarbeidsavtale var inngått mellom ham og morselskapet, og morselskapet hadde en indirekte oppsigelsesadgang ved at det kunne si opp avtalen. Den første oppsigelsen Läckström mottok kom fra morselskapet. Et ytterligere moment i den samlede vurderingen var at ansettelsen i datterselskapet hadde en midlertidig karakter, noe som var signalisert gjennom Läckströms rett til å tre tilbake i morselskapets tjeneste.

Morselskapet ble ansett for å være arbeidsgiver «i den forbindelse som her er aktuell» (s. 1132). Høyesteretts konklusjon innebar følgelig ikke at morselskapet var arbeidsgiver på lik linje med datterselskapet. Retten tok forbehold om at morselskapet ikke nødvendigvis var å anse som arbeidsgiver $i$ andre relasjoner. Dette viser betydningen av å skille mellom primær- og sekundærarbeidsgiver: En primærarbeidsgiver vil være arbeidsgiver $\mathrm{i}$ alle 
relasjoner. Sekundærarbeidsgivers posisjon må derimot avgjøres ut fra en konkret vurdering for den enkelte forbindelse.

På bakgrunn av at både datterselskapet og morselskapet ble ansett for å være Läckströms arbeidsgivere, ble spørsmålet hvor Høyesterett skulle plassere arbeidsgiveransvaret. Førstvoterende bemerket kort at arbeidsmiljøloven ikke kunne være til hinder for at et datterselskap og et morselskap hadde felles arbeidsgiveransvar hvor arbeidsgiverfunksjonene var delt slik som i denne saken. Det fulgte av aml. (1977) § 14 at «arbeidsgiveren» pliktet å overholde bestemmelsene i arbeidsmiljøloven. I et tilfelle med to arbeidsgivere var dette etter Høyesteretts oppfatning ikke til hinder for at begge ble holdt ansvarlige. Forutsetningen for et felles arbeidsgiveransvar var imidlertid at arbeidsgiverfunksjonene var delt slik de var i den aktuelle saken. Det fremgår av den samlede vurdering Høyesterett la til grunn at morselskapet hadde enkelte arbeidsgiverfunksjoner, som forhandlingsmyndighet i forbindelse med lønns- og pensjonsrettigheter. Samtidig hadde morselskapet en viss instruksjonsmyndighet; Läckström var forpliktet til å følge morselskapets direktiver. Det fremgår ikke hvilke arbeidsgiverfunksjoner som ble utøvet av datterselskapet, men det må kunne legges til grunn at funksjoner som ikke uttrykkelig var overført til morselskapet gjennom hovedarbeidsavtalen, lå hos datterselskapet. Blant annet innebærer dette at instruksjonsmyndighet ut over direktivene fra morselskapet var en arbeidsgiverfunksjon som ble opprettholdt av datterselskapet. Gjennomgangen viser at det var en flytende overgang mellom hvilke arbeidsgiverfunksjoner det enkelte selskap utøvde, og det er nærliggende å anta at dette hadde betydning for plasseringen av ansvar. Avslutningsvis er det grunn til å påpeke at førstvoterende bemerket at uttalelsen gjaldt sammensatte arbeidsgiverforhold med et morselskap og et datterselskap. Rettsoppfatningen om et felles arbeidsgiveransvar kan derfor ikke isolert sett overføres direkte fra Wärtsilädommen til sammensatte arbeidsgiverforhold der arbeidsgiveraktørene ikke tilhører samme konsern.

Ved vurderingen av om morselskapet hadde «arbeidsgiveransvar overfor [Läckström]», tok lagmannsrettens mindretall utgangspunkt $i$ at spørsmålet i saken gjaldt «identifikasjon i relasjon til arbeidsmiljøloven». ${ }^{89}$ Spørsmålet er om Høyesterett også vurderte det rettslige utgangspunktet som et spørsmål om identifikasjon. Høyesterett sluttet seg som nevnt til de synspunkter lagmannsrettens mindretall hadde uttrykt, men formulerte aldri problemstillingen som et spørsmål om "identifikasjon" i relasjon til loven. Førstvoterende uttalte at 
han var kommet til «at også morselskapet måtte anses som arbeidsgiver etter arbeidsmiljфloven $\S 4$ » (s. 1132; mine kursiveringer). Konklusjonen isolert sett kan tyde på at morselskapet måtte anses som Läckströms arbeidsgiver uavhengig av datterselskapet. Imidlertid la Høyesterett til grunn den samme samlede vurderingen som lagmannsrettens mindretall, og kom til at morselskapet og datterselskapet var felles ansvarlige overfor Läckström. Sett i sammenheng med Høyesteretts tilslutning til de synspunktene lagmannsrettens mindretall hadde lagt til grunn, taler sterke grunner for at Høyesterett fant at morselskapet måtte identifiseres med datterselskapet i relasjon til arbeidsmiljøloven.

\subsection{Rt. 1993 s. 345 Matherson-Selig}

\subsection{Saken}

Saken gjaldt gyldigheten av oppsigelser som skyldtes produksjonsavvikling. Bakgrunnen for avviklingen var ordremangel som følge av at arbeidsgiverbedriften Matherson-Selig European AS (MSE) var utkonkurrert av et annet firma, Vogelsang Eurocolour A/S (VE). I forkant av oppsigelsene hadde MSE imidlertid sikret seg en majoritetsandel $(51,25 \%)$ av aksjene i VE.

Prinsipalt var det lagt ned påstand om at oppsigelsene skulle kjennes ugyldige, samt om erstatning. Subsidiært krevde arbeidstakerne fortrinnsrett til ansettelser i VE. MSE ba om fratredelseskjennelse. Høyesteretts kjæremålsutvalg skulle ta stilling til et videre kjæremål over lagmannsrettens kjennelse, som stadfestet byrettens avgjørelse om at arbeidstakerne ikke trengte å fratre ved oppsigelsestidens slutt. Kjæremålsutvalget fant at lagmannsretten hadde tolket loven riktig da den sluttet seg til byrettens konklusjon, som gikk ut på at MSE og VE måtte anses for å være samme virksomhet med hensyn til aml. (1977) § $60 \mathrm{nr} .2$ og 3, samt $§ 61 \mathrm{nr} .4$. Anken ble følgelig forkastet.

\subsection{Analyse og vurdering}

Konsekvensen av at MSE og VE ble ansett for å være samme virksomhet, var at de begge ble holdt ansvarlig som arbeidsgivere for overholdelsen av stillingsvernsreglene. Spørsmålet er dermed hvilken lovtolkning som ble lagt til grunn da det ble konkludert med at de to selskapene utgjorde samme virksomhet i relasjon til stillingsvernsreglene. 
Partsforholdet og problemstillingen kan illustreres slik:

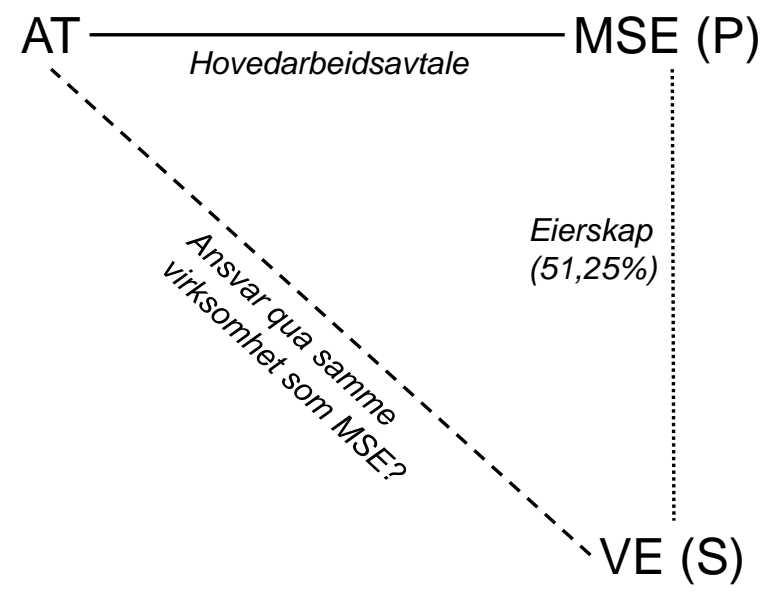

Byretten, som lagmannsretten sluttet seg til, ${ }^{90}$ fremholdt i sine premisser at:

«[b]egrepet virksomheten" i aml. tar sikte på virksomheten i vid forstand/virksomheten som sådan. Eierforhold og organisasjonsform blir i denne sammenheng underordnet. ... i forhold til datterselskaper innenfor samme konsern, bør utgangspunktet være de rettslige og praktiske muligheter bedriftsledelsen har for å ivareta arbeidstakernes interesser i den konkrete situasjon ...». ${ }^{91}$

Byretten la til grunn en vid forståelse av virksomhetsbegrepet, hvor eierforhold og organisasjonsform var underordnet. Særlig i konsernforhold måtte det legges vekt på hvilke rettslige og praktiske muligheter bedriftsledelsen hadde for å ivareta sitt ansvar som arbeidsgiver. Etter denne forståelsen kunne «virksomheten» etter aml. (1977) §§60 og 61 omfatte både MSE og VE på bakgrunn av at de drev samme aktivitet, og at MSE gjennom sin majoritetsandel kunne ha både praktiske og rettslige muligheter til tilby arbeidstakerne stillinger i VE.

\subsection{Slutninger}

Grunnen til at Rt. 1993 s. 345 Matherson-Selig kan anses som et sammensatt arbeidsgiverforhold, er at Høyesterett åpnet for at arbeidstakernes stillingsvern var knyttet til aktivitetene i både MSE og VE, jf. aml. (1977) $§ § 0$ og 61. Arbeidstakerne kunne dermed

91 Jf. Sarpsborg byretts kjennelse 19. oktober 1992 (92-00947 A) 
ha krav på stillinger i VE. Indirekte innebar rettens konklusjon at VE kunne bli ansvarlig som arbeidsgiver.

I utgangspunktet var arbeidstakerne ansatt i MSE; selskapet var primærarbeidsgiver (P). På bakgrunn av at VE også kunne være ansvarlig for at stillingsvernsreglene ble overholdt, kan VE anses som ansvarlig sekundærarbeidsgiver (S) i relasjon til arbeidstakernes stillingsvern.

Vurderingen av denne saken som et tilfelle av sammensatte arbeidsgiverforhold er imidlertid bare én forståelse. Avgjørelsen kan også leses som en ren identifikasjon av MSE og VE etter arbeidsmiljøloven.

\subsection{Rt. 1997 s. 623 PPD}

\subsection{Saken}

I Rt. 1997 s. 623 PPD fant Høyesterett under dissens (4-1) at det ikke var grunnlag for å anse kommunene bak et interkommunalt Pedagogisk-Psykologisk Distriktssenter (PPDsenteret) for å være arbeidsgivere sammen med senteret. Avgjørelsen kan dermed bidra til å kartlegge rammene for sammensatte arbeidsgiverforhold.

Tvisten gjaldt gyldigheten av oppsigelser, som følge av nedleggelsen av skole- og boavdelingen ved PPD-senteret. Senteret var etablert av seks kommuner, og fylkeskommunen hadde senere tiltrådt samarbeidet. Ved tiltredelsen ble det inngått en samarbeidsavtale med kommunene og fylkeskommunen som parter. I PPD-senterets styre satt representanter for avtalepartene og de ansattes arbeidstakerorganisasjoner. Finansieringen kom ved bevilgninger over kommunenes skolebudsjett, samt bidrag fra fylkeskommunen. Senteret foretok selv tilsetting av både daglig leder og andre ansatte. Budsjettene ble fram til 1989 lagt fram «for kommunane til endeleg vedtak» (s. 623), men ble siden fastsatt av styret med endelig virkning. Det var senterets styre som i 1994 besluttet at skole- og boavdelingene skulle nedlegges. De oppsagte arbeidstakerne krevde å bli tilbudt stillinger i samarbeidskommunene. Under dissens (4-1) ble kommunene frifunnet.

Innledningsvis tok Høyesterett stilling til om senteret var et eget rettssubjekt. Høyesterett la til grunn at dette måtte avgjøres ut fra en konkret vurdering av «virksomhetens formuesmasse [og] den grad av selvstendighet styret har i forhold til deltakerkommunene». Basert på blant annet at senteret opptrådte utad under eget navn, disponerte egne midler og bygget på et «samarbeid mellom forholdsvis mange kommuner», konkluderte Høyesterett enstemmig med at senteret var et eget rettssubjekt. Senteret var dermed «arbeidsgiver for de ansatte ved senteret» etter aml. $§ 4$ (s. 631). 
Hovedspørsmålet i tvisten var hvorvidt omplasseringsplikten etter aml. (1977) $\S 60 \mathrm{nr} .2$ kunne gjøres gjeldende overfor samarbeidskommunene. Partskonstellasjonen og problemstillingen kan dermed illustreres slik:

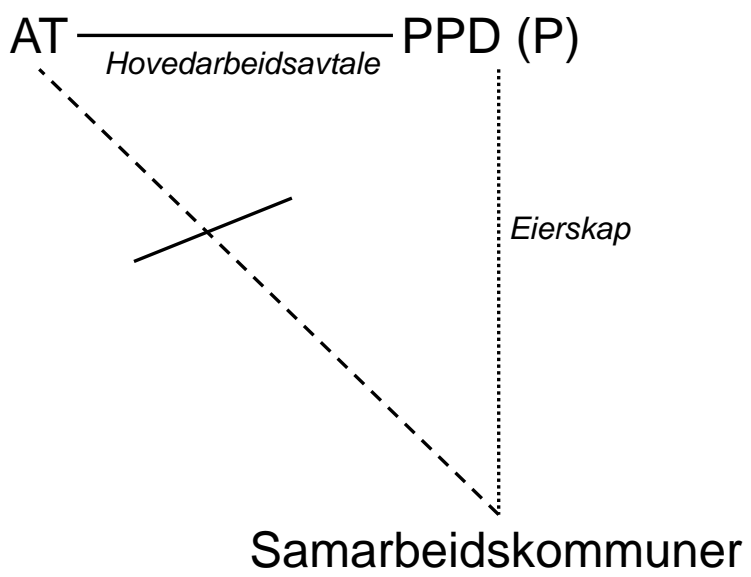

\subsection{Analyse og vurdering}

Spørsmålet var dermed om samarbeidskommunene også var «å anse som de oppsagte arbeidstakernes arbeidsgivere» (s. 630). Førstvoterende, for flertallet, formulerte problemstillingen slik:

«Det har i rettspraksis vært lagt til grunn at flere rettssubjekter kan ha et arbeidsgiveransvar etter arbeidsmiljøloven [1977] $\$ 60 \mathrm{nr} 2$ dersom arbeidsgiverfunksjonene har vært delt mellom dem, jf Rt-1990-1126». ${ }^{92}$

Førstvoterende viste til Rt. 1990 s. 1126 Wärtsilä som prejudikat for at flere rettssubjekter kan ha et arbeidsgiveransvar. Vilkåret for dette var imidlertid at arbeidsgiverfunksjonene var delt mellom dem.

I sin vurdering fremhevet førstvoterende at styret tilsatte arbeidstakerne, utøvde styringsretten over de ansatte og selv opptrådte i lønnsforhandlinger. Et moment han ikke tilla noen vekt var at det overfor senterets ansatte var anvendt generelle tariffavtaler for kommunalt ansatte, og at det ikke var fremforhandlet noen egen tariffavtale med senteret som arbeidsgiver. Han konkluderte på bakgrunn av disse momenter at alle sentrale arbeidsgiverfunksjoner hadde «tilligget og blitt utøvet av styret ved PPD-senteret» (s. 631). 
Førstvoterende bemerket så at faktum i Wärtsilä-saken ${ }^{93}$ «på vesentlige punkter» stod i en annen stilling enn saksforholdet i PPD-saken. I Wärtsilä-saken var arbeidsforholdet med datterselskapet «fastsatt $\mathrm{i}$ en avtale mellom morselskapet og direktøren, som forutsatte at arbeidsforholdet ikke ville bli varig og at direktøren hadde rett til å gjeninntre i morselskapets tjeneste ved opphør av avtalen med datterselskapet» (s. 632). Deretter fremhevet han at «[u]ttalelser $\mathrm{i}$ rettspraksis om forholdet mellom selskaper i et konsernforhold, kan etter mitt syn ikke få anvendelse ved et interkommunalt fellesforetak». ${ }^{94}$

I sin bemerkning til saksforholdet i Wärtsilä-saken beskrev førstvoterende innledningsvis hvordan forholdet mellom morselskapet og arbeidstakeren i den saken var forskjellig fra forholdet mellom arbeidstakerne ved PPD-senteret og samarbeidskommunene. Dette forholdet var i Wärtsilä-saken preget av en mye sterkere tilknytning mellom partene enn i PPD-saken. Deretter kommenterte han hvilken vekt som kunne tillegges Høyesteretts vurdering av "forretningsforholdet" mellom morselskapet og datterselskapet i Wärtsiläsaken. Etter hans oppfatning kunne ikke «[u]ttalelser ... om forholdet mellom selskaper i konsernforhold» tillegges noen vekt ved vurderingen av et interkommunalt fellesforetak. De to formene for selskapskonstellasjoner var etter førstvoterendes oppfatning så ulike at de måtte vurderes forskjellig.

Arbeidstakerne anførte at samarbeidskommunene måtte ha arbeidsgiveransvar som følge av at de aktuelle oppgavene var pålagt kommunene ved lov. Anførselen førte ikke frem. Førstvoterende var heller ikke enig med arbeidstakersiden i at Arbeidsrettens dom i ARD 1980 s. 79 kunne tillegges noen avgjørende betydning. Han la til grunn at «saken på flere punkter stod i en annen stilling enn vår sak» (s. 632). En anførsel om arbeidsgiveransvar for kommunene som følge av uklarhet fra PPD-senterets side førte heller ikke frem. Etter flertallets oppfatning ga ikke sakens faktum arbeidstakerne rimelig grunn til å tro at de var blitt ansatt av samarbeidskommunene (s. 632 flg.).

Annenvoterende, i mindretallet, la stor vekt på «hva de [ansatte] hadde grunn til å forvente» (s. 635). Arbeidstakernes "tilsettingsbrev" inneholdt trykte formularer for tilsetting i kommunale stillinger, hvor det var påført at de var tilsatt i en av samarbeidskommunene. Samtidig gikk både arbeidstakerne og PPD-senteret inn i

94 Jf. Rt. 1997 s. 623 PPD (s. 632). 
forhandlinger om nedleggelse med oppfatning om at arbeidstakerne hadde fortrinnsrett til arbeid i samarbeidskommunene, jf. aml. (1977) §67. Han hadde dermed en annen oppfatning enn førstvoterende av hvordan arbeidsforholdet som helhet hadde fremstått for arbeidstakerne.

Annenvoterende la følgelig til grunn at PPD-senteret var å anse som et eget rettssubjekt, men anså ikke dette for å være til hinder for at også kommunene kunne være arbeidsgivere. Han viste i denne sammenheng til Wärtsilä-dommen, og fremhevet at «kommunenes ansvar for og sterke styring med virksomheten» talte for at de to sakene måtte bedømmes likt (s. 636). PPD-senterets oppgaver var pålagt kommunene ved lov, og kommunene hadde en «sterk overordnet styring med virksomheten» (s. 635). Selv om PPD-senteret utøvde de sentrale arbeidsgiverfunksjonene, kunne dette etter annenvoterendes oppfatning være et resultat av kompetansedelegering fra kommunene. Samtidig måtte stillingenes tariffmessige tilknytning til kommunene tillegges vekt.

I motsetning til førstvoterende mente annenvoterende at Arbeidsrettens dom i ARD 1980 s. 79 måtte tillegges betydelig vekt. Etter annenvoterendes syn kunne Arbeidsrettens rettsoppfatning overføres direkte til PPD-saken. Arbeidsretten hadde i den saken lagt til grunn at «de ansatte [ved et interkommunalt skolepsykologisk kontor] hadde stillingsvern i forhold til deltakerkommunene» (s.636). Som et endelig moment bemerket annenvoterende at stillingsvernets betydning for arbeidstakerne måtte veie tyngre enn administrative hensyn. Selv om det ville by på administrative utfordringer for kommunene å tilby stillinger sammen, kunne ikke dette tillegges vesentlig vekt.

Annenvoterende bemerket avslutningsvis at hans konklusjon innebar at «virksomheten» $\mathrm{i}$ aml. (1977) $§ 60$ nr. 2 ikke kunne være begrenset til PPD-senteret, en rettsoppfatning han fant støtte for i Arbeidsrettens ovennevnte dom. Han sluttet seg til deretter til arbeidstakernes påstand om at oppsigelsene måtte kjennes ugyldige.

\subsection{Sideblikk til ARD 1980 s. 79}

Arbeidsrettens dom i ARD 1980 s. 79, som det ble vist til under punkt 4.72, gjaldt gyldigheten av oppsigelser som følge av at en interkommunal pedagogisk-psykologisk rettledningstjeneste (pp-tjeneste) ble omorganisert. Tjenesten var etablert av seks kommuner gjennom en samarbeidsavtale, og ble administrert av et eget styre med én representant fra hver kommune. Ansettelser ble foretatt av styret. Etter en tid ble 
samarbeidsavtalen sagt opp. Tjenesten måtte følgelig omorganiseres, og i den prosessen ble de ansatte sagt opp. Arbeidsretten fant at oppsigelsene var ugyldige. ${ }^{95}$

Spørsmålet for Arbeidsretten var om styret ved pp-tjenesten hadde tilstrekkelig saklig grunnlag til å si opp arbeidstakerne. Etter en konkret helhetsvurdering ble det konkludert med at:

«Arbeidsretten anser det klart at de samarbeidende kommuner, som var de ankende parters reelle arbeidsgivere med bl.a. ansvar for bevilgning av tilstrekkelige midler til lønninger m.v., hadde et selvstendig arbeidsgiveransvar overfor disse. Retten finner det lite tvilsomt at dette ansvar ikke bortfalt ved omorganiseringen» (s. 89).

Det knytter seg en viss usikkerhet til hva som kan utledes av denne avgjørelsen. Arbeidsretten tok tilsynelatende ikke stilling til om pp-tjenesten utgjorde et eget rettssubjekt. Uttalelsen kan dermed gi uttrykk for to ulike oppfatninger: Den første er at kommunene var «reelle arbeidsgivere» ved siden av pp-tjenestens posisjon som formell arbeidsgiver. Det er i denne sammenheng verdt å legge merke til at pp-tjenesten ble representert ved en av kommunene i Arbeidsretten, noe som taler for at den ikke var et eget rettssubjekt. Den andre oppfatningen er at pp-tjenesten ikke var et eget rettssubjekt, og at kommunene på denne bakgrunn i realiteten var arbeidsgivere.

Som følge av denne uklarheten er det naturlig å tolke avgjørelsen i lys av hva Høyesterett la til grunn i PPD-dommen. Spørsmålet om pp-tjenesten var å anse som arbeidsgiver ved siden av kommunene ble verken kommentert av flertallet eller mindretallet. Førstvoterende argumenterte for at PPD-senteret fremstod som mer uavhengig enn pp-tjenesten (s. 632). Dette tyder på at Høyesteretts flertall ikke anså pp-tjenesten for å være et selvstendig rettssubjekt. Mindretallet fant støtte for sitt resultat i Arbeidsrettens avgjørelse, uten å kommentere nærmere om pp-tjenesten utgjorde et eget rettssubjekt. På denne bakgrunn kan Arbeidsrettens avgjørelse i ARD 1980 s. 79 vanskelig hevdes å være et prejudikat for sammensatte arbeidsgiverforhold i relasjon til stillingsvernet. 


\subsection{Sammenfatning og slutninger}

I PPD-dommen konkluderte Høyesterett (under dissens 4-1) med at oppsigelser som følge av at et PPD-senter la ned en avdeling var gyldige. Det var bare PPD-senteret som hadde arbeidsgiveransvar overfor de oppsagte arbeidstakerne; samarbeidskommene som drev senteret ble ikke ansett for å være arbeidsgivere. Mindretallet la til grunn at både PPDsenteret og kommunene måtte holdes ansvarlige som arbeidsgivere for arbeidstakernes stillingsvern. Selv om Høyesteretts konklusjon innebar at et sammensatt arbeidsgiverforhold ikke ble ansett for å foreligge, tyder dissensen og mindretallets votum på at man her befant seg $\mathrm{i}$ et grenseområde. Avgjørelsen har dermed relevans for fremstillingen av sammensatte arbeidsgiverforhold.

Ved vurderingen av om de oppsagte arbeidstakerne hadde flere arbeidsgivere, tok en samlet Høyesterett utgangspunkt i Wärtsilä-saken. ${ }^{96}$ Fra domspremissene utledet førstvoterende at «flere rettssubjekter kan ha et arbeidsgiveransvar etter arbeidsmiljøloven [1977] § $60 \mathrm{nr} 2$ dersom arbeidsgiverfunksjonene har vært delt mellom dem»(s. 631). Førstvoterende knesatte dermed rettsoppfatningen om at arbeidsmiljøloven ikke er til hinder for at flere rettssubjekter har arbeidsgiveransvar etter arbeidsmiljøloven.

Førstvoterendes slutning i PPD-saken skiller seg imidlertid på to punkter fra den opprinnelige uttalelsen i Wärtsilä-saken. For det første la Høyesterett i Wärtsilä-avgjørelsen til grunn at «et datterselskap og et morselskap kan ha felles arbeidsgiveransvar» (s. 1132). I PPD-saken nevnte ikke førstvoterende et slikt "felles" ansvar. I stedet la han til grunn at «flere rettssubjekter» kunne ha et ansvar (s. 631). Spørsmålet er om førstvoterende dermed tok sikte på å referere eller korrigere den tidligere uttalelsen. Ved at han la til grunn at rettsoppfatningen hadde anvendelse for interkommunale virksomheter, og ikke bare for selskaper i konsernforhold, ble rettsoppfatningens anvendelsesområde utvidet i forhold til sin ordlyd. Det er på den annen side ingen holdepunkter for at førstvoterende i PPDdommen tok sikte på å avgrense mot et "felles" ansvar mellom ansvarssubjektene. Det kan derfor ikke tillegges vekt at dette momentet ikke ble nevnt. For det andre fremhevet førstvoterende i PPD-saken at uttalelsen i Wärtsilä-avgjørelsen gjaldt aml. (1977) §60 nr. 2. Spørsmålet er om dette var ment som en presisering av uttalelsen, eller en henvisning til at uttalelsen gjaldt samme forhold som i PPD-avgjørelsen, og at den dermed kunne overføres direkte. I Wärtsilä-avgjørelsen uttalte Høyesterett seg om arbeidsmiljøloven på generelt grunnlag, uten å spesifisere om retten kun refererte til enkelte bestemmelser. I 
PPD-avgjørelsen kommenterte ikke førstvoterende dette nærmere, og gode grunner taler derfor for at han ikke tok sikte på å innskrenke anvendelsesområdet for Høyesteretts uttalelse i Wärtsilä-avgjørelsen.

Det følger av denne gjennomgangen at den rettsoppfatning Høyesterett ga uttrykk for i Wärtsilä-avgjørelsen også kan få anvendelse på andre selskapskonstellasjoner enn konsernforhold. Arbeidsmiljøloven er dermed ikke til hinder for at flere rettssubjekter kan ha et felles arbeidsgiveransvar dersom arbeidsgiverfunksjonene er delt mellom dem.

I forkant av sin konkrete vurdering av partsforbindelsene kom førstvoterende med en generell bemerkning om vurderingen av "forretningsforholdet". Etter hans oppfatning kunne ikke uttalelser om selskaper i konsernforhold anvendes når interkommunale fellesforetak skulle vurderes (s. 632). Wärtsilä-saken hadde derfor ingen relevans i denne sammenheng. Annenvoterende delte ikke denne oppfatningen, og argumenterte for at PPDsaken måtte bedømmes på samme måte som Wärtsilä-saken som følge av samarbeidskommunenes ansvar for og sterke styring med virksomheten (s. 635 flg.). Flertallets konklusjon innebærer at man må ta hensyn til hvilken type partskonstellasjon som foreligger i "forretningsforholdet" når man skal foreta en konkret vurdering av om det foreligger et sammensatt arbeidsgiverforhold.

Ved den konkrete vurderingen av forholdet mellom samarbeidskommune og arbeidstakerne, la flertallet avgjørende vekt på at PPD-senteret, og ikke kommunene, både formelt og reelt hadde «alle sentrale arbeidsgiverfunksjoner»(s. 631). Anvendelsen av generelle tariffavtaler for kommunalt ansatte ble i denne sammenheng ikke tillagt vekt. Mindretallet la til grunn at man kunne se arbeidsgiverfunksjonene som delegert fra kommunene, og fremhevet at tariffavtalene måtte tillegges vekt som moment ved vurderingen. Flertallet fant videre at det ikke kunne legges avgjørende vekt på at Arbeidsrettens dom i ARD 1980 s. 79 ga støtte for et annet resultat; den var for ulik PPDsaken. Mindretallet var derimot av den oppfatning at Arbeidsrettens rettsoppfatning var direkte overførbar. Flertallet la endelig til grunn at verken usikkerheten knyttet til arbeidstakernes fortrinnsrett til stillinger i kommunene, eller det at PPD-senterets oppgaver var pålagt ved lov, kunne tillegges vekt. Mindretallet var uenig i dette. Avslutningsvis fremhevet mindretallet at vurderingen av om PPD-senteret var et eget rettssubjekt bygget på en konkret vurdering av forholdet mellom kommunene og PPD-senteret. Det ville virke tilfeldig overfor arbeidstakerne om en så "usikker" vurdering skulle ha avgjørende betydning for deres stillingsvern (s. 635). Av flertallets argumentasjon og konklusjon kan det utledes at det avgjørende momentet i vurderingen var hvem som formelt og reelt hadde arbeidsgiverfunksjonene. 
Som en avsluttende betraktning kan det påpekes at de reelle forhold spilte en avgjørende rolle i vurderingen. Selv om formelle forhold som partsangivelser i de individuelle arbeidsavtalene og tariffavtalen talte for at kommunene var arbeidsgivere, ble ikke disse forholdene tillagt avgjørende vekt. De reelle forhold hadde ikke gitt arbeidstakerne grunn til å tro at kommunene var deres arbeidsgivere.

Annenvoterendes vektlegging av usikkerheten knyttet til PPD-senterets status som rettssubjekt kan imidlertid ikke avvises. Tilsvarende gjelder for selskaper under stiftelse. Overfor arbeidstakerne kan det virke tilfeldig dersom det reelle forholdet mellom to enheter som kan være arbeidsgivere skal ha avgjørende betydning for deres stillingsvern.

\subsection{Praksis fra underordnede domstoler}

\subsection{Innledende bemerkninger}

Fra underordnede domstoler har vi flere eksempler på sammensatte arbeidsgiverforhold i relasjon til stillingsvernet. I dette avsnittet gjennomgår jeg enkelte slike avgjørelser med sikte på å illustrere ulike problemstillinger knyttet til sammensatte arbeidsgiverforhold, samtidig som avgjørelsene viser hvordan den rettspraksis som er analysert over er blitt tolket og anvendt. Jeg skiller i denne sammenheng mellom tre hovedgrupper av avgjørelser: Den første består av Adressa-avgjørelsen, hvor to selskaper ble holdt ansvarlige som arbeidsgivere på grunnlag av "forretningsforholdet" mellom dem, og fordi de begge utøvet arbeidsgiverfunksjoner. Den andre består av avgjørelser hvor flere selskaper ble holdt ansvarlige som arbeidsgivere på grunn av det nære forholdet dem imellom. Den tredje gruppen inneholder Oddstøl-avgjørelsen, hvor lagmannsretten kom til at det ikke forelå noe sammensatt arbeidsgiverforhold. Skillet baserer seg på avgjørelsenes begrunnelser i henhold til premissene.

\subsection{Flere arbeidsgivere - sammenblanding og delte arbeidsgiverfunksjoner}

a) RG 2004 s. 255 Adressa (Frostating)

Saken gjaldt spørsmålet om et morselskap kunne være ansvarlig som arbeidsgiver for to oppsagte arbeidstakere som var ansatt i datterselskapet.

De to arbeidstakerne var ansatt i Adresseavisens Telefontjenester AS (Telefontjenesten), men hevdet at morselskapet Adresseavisen ASA (Adressa) hadde arbeidsgiveransvar i relasjon til oppsigelsesvernet. I utgangspunktet hadde arbeidstakerne vært ansatt med abonnementssalg $\mathrm{i}$ deltids kveldsstillinger hos datterselskapet. I forbindelse med et samarbeidsprosjekt mellom de to selskapene ble de midlertidig ansatt for ett år i heltidsstillinger på dagtid, også hos datterselskapet. Prosjektarbeidet bestod av å selge nettannonser for Adressa.no og Finn.no. De to arbeidet samlokalisert med Adressas markedsavdeling, og samarbeidet med de ansatte der. Halvveis ut i prosjektåret ble det 
færre arbeidsoppgaver for de to arbeidstakerne, og de ble sysselsatt med salg av andre produkter for Adressa. Ordningen kom i stand gjennom avtale mellom Adressa og Telefontjenesten. Da arbeidstakerne igjen måtte forholde seg til arbeidsavtalen om deltids kveldsstilling i Telefontjenesten, oppstod tvisten. Spørsmålet for retten var om situasjonen ved dagarbeidet, samlet sett, ga grunnlag for arbeidsgiveransvar for Adressa i relasjon til oppsigelsesvernet. Under dissens (4-3) konkluderte retten med at oppsigelsene var usaklige, og følgelig ugyldige, på bakgrunn av at Adressa var arbeidsgiver for arbeidstakerne. Anken til Høyesterett ble nektet fremmet, jf. HR-2004-372-U.

Det var på det rene at Telefontjenesten var arbeidsgiver for de to arbeidstakerne. Spørsmålet var om også Adressa kunne pålegges arbeidsgiveransvar for de to. Det ble lagt til grunn at det i rettspraksis var åpnet for at flere selskaper kunne ha et arbeidsgiveransvar dersom utøvelsen av arbeidsgiverfunksjoner hadde vært delt mellom dem. Som et rettslig utgangspunkt bemerket retten at selv om de formelle forhold som hovedregel var avgjørende, måtte den rettslige vurderingen ta hensyn til at realitetene ikke alltid stemte overens med de formelle strukturer. Arbeidsforholdet måtte vurderes ut fra situasjonen, den typen arbeid som de ansatte utførte, og hvor involvert morselskapets ledelse og ledere var i organiseringen og kontrollen av datterselskapet og arbeidstakernes hverdag. Lagmannsretten la til grunn at det var den konkrete situasjonen for dagarbeidet det første halvåret av prosjektet som var gjenstand for vurdering; den tiden de to arbeidstakerne drev med annonsesalg. Oppgavene som ble tildelt i prosjektets siste halvår, hadde ingen selvstendig betydning for vurderingen; disse var et resultat av forhandlinger mellom selskapene for å sikre sysselsetting av arbeidstakerne ut prosjekttiden.

Spørsmålet var om det forelå «et særskilt grunnlag» for å fravike det som formelt var avtalt. Her delte retten seg i et flertall og et mindretall, hvor flertallet fant at et slikt særskilt grunnlag forelå.

Det var enighet blant dommerne om at det hersket en viss samrøre mellom selskapene med hensyn til prosjektet, men det var uenighet om hvor graverende den var, og følgelig hvilken rettslig konsekvens den skulle ha. "Forretningsforholdet" mellom morselskapet og datterselskapet var etter flertallets syn preget av en sterkere overordnet styring enn det som fulgte av eierskap gjennom konsern og styre. Dette ble illustrert gjennom organiseringen, strukturen og mangelen på formaliteter mellom selskapene: Verken prosjektet eller leie av selskapslokaler var nedfelt i skriftlige avtaler, datterselskapet ble internt ansett for å være en del av Adressa. Mindretallet argumenterte for at det samrøret som eksisterte var naturlig ut fra omstendighetene, blant annet som følge av at Telefontjenesten var i en oppstartsfase og derfor krevde tettere oppfølgning fra morselskapet. 
Med hensyn til forholdet mellom Adressa og de to arbeidstakerne fremhevet flertallet at dette var preget av uklare rollefordelinger. Det var representanter for Adressa som utøvet arbeidsgiverfunksjonene, og de to arbeidstakerne forholdt seg til både Adressa og Telefontjenesten som arbeidsgivere. Mindretallet anså utøvelsen av arbeidsgiverfunksjoner for å være en naturlig følge av at de to arbeidstakerne utførte oppdrag direkte for avisa.

Avslutningsvis bemerket flertallet at de to arbeidstakernes arbeid og skjebne i realiteten ble avgjort av Adressa. De hadde dermed to arbeidsgivere som måtte likestilles. Telefontjenesten var formell arbeidsgiver etter hovedarbeidsavtalen; selskapet var primærarbeidsgiver for de to arbeidstakerne. Som følge av Adressas utøvelse av arbeidsgiverfunksjoner, og hensett til de bakenforliggende realiteter i forholdet mellom Adressa og Telefontjenesten, måtte også Adressa være arbeidsgiver; selskapet var arbeidstakernes sekundærarbeidsgiver. Etter flertallets oppfatning var det kun den formelle strukturen som forhindret at Adressa hadde arbeidsgiveransvar alene. Flertallets konklusjon innebar at Telefontjenesten ikke var å anse som en egen "virksomhet" etter aml. (1977) § 60 nr. 2; virksomheten var konsernet som sådan.

\section{b) Sammenfatning}

I Adressa-saken ble et morselskap og et datterselskap sammen holdt ansvarlige som arbeidsgivere for noen oppsagte arbeidstakere. Formelt sett var arbeidstakerne ansatt i datterselskapet; dette var primærarbeidsgiver. I forbindelse med et samarbeidsprosjekt mellom morselskapet og datterselskapet skulle arbeidstakerne utføre oppgaver for morselskapet. Spørsmålet var imidlertid om reelle forhold ga grunnlag for å fravike det formelle utgangspunktet, og dermed anse morselskapet for å være arbeidsgiver etter aml. (1977) $§ 4$.

Flertallet vurderte i denne sammenheng både "forretningsforholdet" mellom morselskapet og datterselskapet, og forholdet mellom morselskapet og arbeidstakerne. Morselskapet ble ansett for å ha en sterkere styring med datterselskapet enn det som var normalt i konsernforhold. Det ble lagt avgjørende vekt sammenblandingen mellom de to selskapene, og mangelen på etterlevelse av de formelle strukturene. Dette kom også til uttrykk overfor arbeidstakerne. Morselskapet utøvde for $\emptyset$ vrig arbeidsgiverfunksjoner overfor arbeidstakerne i prosjektperioden. På bakgrunn av situasjonen under den ettårige prosjektperioden konkluderte lagmannsretten med at også morselskapet måtte være arbeidsgiver; det var sekundærarbeidsgiver.

Flertallets konklusjon, som innebar at arbeidstakerne sto i sammensatte arbeidsgiver-

forhold, var basert på den samme vurderingen som var lagt til grunn i Rt. 1990 s. 1126 Wärtsilä; en samlet vurdering av "forretningsforholdet" mellom aktørene på arbeidsgiver- 
siden og "sekundærarbeidsforholdet" mellom arbeidstaker og sekundærarbeidsgiver. Adressa ble holdt ansvarlig som arbeidsgiver, til tross for at arbeidsgiverposisjonen ikke fulgte av noen avtale mellom partene. Grunnlaget for Adressas arbeidsgiverposisjon var aml. (1977) § 4; saksforholdet ga grunnlag for et lovbasert delt arbeidsgiverposisjon.

Dersom flertallet hadde lagt mer vekt på arbeidsavtalen, og ansett prosjektarbeidet under morselskapets ledelse som en tidsbegrenset utplassering, kunne imidlertid konklusjonen blitt en annen. Etter avtalen var samarbeidsprosjektet kun ettårig, og etter dette ville arbeidstakerne vært forpliktet til å gå tilbake i sine gamle stillinger på avtalemessig grunnlag. Flertallet fant imidlertid grunn til å fravike det som formelt var avtalt, og identifiserte de to selskapene med hverandre. Avgjørelsen viser hvordan sammenblandingen mellom selskaper kan få avgjørende betydning $i$ en arbeidsrettslig sammenheng.

\subsection{Praksis med vekt på et utvidet virksomhetsbegrep}

a) RG 1996 s. 463 Rieber (Gulating)

Rieber-saken gjaldt spørsmål om en arbeidstaker ble oppsagt da vedkommende ble overført fra en stilling i ett selskap til en stilling i et annet selskap i samme konsern. Lagmannsretten kom til at arbeidstakeren ikke ble oppsagt ved overføringen. Ett av spørsmålene var om konsernet var å anse som én virksomhet. Retten tok utgangspunkt i at «[d]atterselskaper innenfor samme konsern må klart regnes som en virksomhet». ${ }^{97}$ «Selvstendige bedrifter» innenfor samme konsern skulle ikke nødvendigvis vurderes annerledes. I denne sammenheng la retten Fanebusts vurderinger ${ }^{98}$ og Rt. 1993 s. 345 Matherson-Selig til grunn. Lagmannsretten fant at det måtte ligge innenfor selskapets styringsrett å omforme selskapsstrukturen med etterfølgende konsekvenser for arbeidstakerne. I Rieber-konsernet var det fast praksis at noen selskaper ble nedlagt mens andre oppstod. Arbeidstakere ble $\mathrm{i}$ denne sammenheng flyttet etter behov. Lagmannsretten konkluderte med at konsernet måtte anses som én virksomhet. På bakgrunn av at selskapene var å anse som samme virksomhet, innebar ikke overføringen av arbeidstakeren en oppsigelse.

b) RG 1998 s. 1415 Lincoln Electric (Tфnsberg)

Lincoln Electric-saken gjaldt gyldigheten av oppsigelser i Lincoln Electric Norge (LEN) som følge av fabrikknedleggelse. LEN var et heleiet datterselskap av det multinasjonale

JF. RG 1996 s. 463 Rieber.

98 Jf. Fanebust, Oppsigelse i arbeidsforhold (1989). 
Lincoln Electric Company (LEC). Charles (Chuck) Howard Murray, var «vice president» i LEC og styremedlem i LEN. Som følge av salgssvikt var en god del av LECs produksjon lagt til LEN. LEC bestemte seg for å flytte produksjonen, og LEN nedlagt som et resultat av dette.

Spørsmålet var «hvorvidt LEC [kunne] identifiseres med LEN, eventuelt på den måten at disse selskaper i fellesskap [ble ansett] som arbeidsgivere i relasjon til oppsigelsene» (s. 1441). Selv om byretten formulerte problemstillingen som et spørsmål om morselskapet reelt sett hadde utøvet arbeidsgiverfunksjoner, var det i realiteten kun "forretningsforholdet" mellom LEC og LEN i konsernet som ble vurdert. Byretten tok utgangspunkt i at identifikasjon krevde særskilt grunnlag, og at eierinteresse i seg selv ikke var tilstrekkelig. Bindingene innad i konsernet kunne imidlertid bli så store at det ville være naturlig å la beslutninger tatt i morselskapet få samme virkning som om de var tatt av kompetent organ i datterselskapet. Byretten fremholdt at uten et slikt unntak ville norske preseptoriske rettsregler kunne bli enkle å omgå.

Ved vurderingen ble det lagt vekt på at LECs stans av ordrer til LEN indirekte medførte nedleggelse og masseoppsigelser for datterbedriften, selv om det formelt sett var datterselskapet som stod for nedleggelsesbeslutningen. Morselskapet hadde etter rettens oppfatning en mer sentral posisjon enn en vanlig kunde; selv om "forretningsforholdet" ikke nødvendigvis var annerledes enn i vanlige konsernforhold, medførte morselskapets posisjon som eneste kunde at det måtte anses for å ha bestemmende innflytelse og dermed sterkere styringsmyndighet enn den rene eierinteresse tilsa. I tillegg ble det lagt vekt på at Murray, som kun var et styremedlem, reelt sett var den som hadde beslutningsmyndighet om bonusordningen til ledergruppen i LEN. Etter byrettens oppfatning tydet de nevnte forholdene på at LEN ble «styrt av eller gjennom morselskapet». LEN og LEC måtte dermed «identifiseres som arbeidsgivere i relasjon til de foretatte oppsigelser» (s. 1445).

c) LG-1997-754 - LG-1997-789 - LG-1998-1021 Translatør

Translatør-saken gjaldt gyldigheten av oppsigelse. Spørsmålet var om et aksjeselskap og et personlig advokatfirma var å anse som samme virksomhet, jf. aml. (1977) §§ 60 nr. 1 og 2 og 62(2). Arbeidstakeren ble i utgangspunktet ansatt i advokatfirmaet, men det fulgte av arbeidsavtalen at han formelt sett var ansatt i aksjeselskapet. Han fikk også lønnen utbetalt fra dette selskapet, og fikk som ansatt aksjer der. Lagmannsretten konkluderte på denne bakgrunn at aksjeselskapet var arbeidsgiver.

Spørsmålet var derfor om advokatfirmaet og aksjeselskapet skulle anses som samme virksomhet. Foretakene var eiet av én og samme person. Det var ikke avgjørende for lagmannsretten at foretakene i selskapsrettslig eller skatterettslig forstand var forskjellige 
virksomheter/subjekter. De to selskapene fremstod både utad og innad som en enhet. I tillegg hadde arbeidstakeren i realiteten en sentral rolle begge steder. Lagmannsretten la til grunn at selv om arbeidstakeren skrev under på en erklæring om at aksjeselskapet var arbeidsgiver, og at det personlige firmaet derfor var uten ansvar, kunne ikke dette være avgjørende. Reelt sett var det en så nær sammenheng mellom foretakene, både innad og utad, at de måtte anses som samme virksomhet. De reelle forhold fikk dermed avgjørende betydning. Anken til Høyesterett ble nektet fremmet, jf. HR-1998-561-K.

\section{d) LB-1998-2880 Telepost}

I Telepost-saken konkluderte lagmannsretten med at et morselskap og to datterselskaper måtte anses som samme virksomhet, og at alle dermed var arbeidsgivere overfor arbeidstaker i relasjon til aml. (1977) $§ \S 60$ og 61. Lagmannsretten la vekt på at «en ikke ubetydelig del»av arbeidstakerens arbeidstid var gått med til arbeid for de ulike selskapene. I tillegg ble det tillagt vekt at konsernets virksomhet for øvrig, slik det fremtonte seg for arbeidstaker, ble «drevet uten hensyn til skillet mellom ulike aksjeselskaper».

e) $R G 2001$ s. 1138 Sveits (Borgarting)

Saken gjaldt gyldigheten av en oppsigelse. I forbindelse med omstrukturering ble daglig leder i et norsk selskap sagt opp. Selskapet var en del av et sveitsisk konsern. En av problemstillingene lagmannsretten tok stilling til, var om morselskap og datterselskap var å anse som samme virksomhet etter aml. (1977) $§ 60 \mathrm{nr}$. 2. Lagmannsretten besvarte dette bekreftende, på bakgrunn av at datterselskapet var totalt avhengig av morselskapet, og at det drev svært beskjeden aktivitet på egenhånd. Det ble også påpekt at morselskapet hadde ment å oppfylle sin plikt etter stillingsvernsreglene ved å tilby arbeidstakeren en stilling utenfor det norske selskapet.

f) RG 2007 s. 756 Deep Sea Management (Gulating)

Saken gjaldt spørsmål om forflytning av arbeidstakere innebar en såkalt "endringsoppsigelse", 99 og om disse var ugyldige. Deep Sea Management AS (DSM) og Odfjell Drilling Management AS (ODM) hørte begge til Odfjell Drilling-konsernet under Odfjell Drilling AS (Odfjell). Konsernets virksomhet var organisert slik at ansatte på flytende plattformer var ansatt i DSM, og ansatte på de faste installasjonene var ansatt i ODM. Arbeidstakerne saken gjaldt hadde mottatt arbeidsavtalene sine fra Odfjell. Ifølge 
avtalene var de ansatt i «Odfjell Drilling gruppen». I etterkant av ansettelsene hadde de inngått hyrekontrakter med DSM. Etter en tid i DSM ble arbeidstakerne informert ved brev fra Odfjell om at de ble forflyttet til faste installasjoner. Dette innebar at det ble laget nye ansettelsesavtaler med bytte av ansettelsesforhold fra DSM til ODM. Arbeidstakerne bestred at denne forflyttingen var lovlig.

Lagmannsretten la til grunn at adgangen til å forflytte arbeidstakerne måtte bero på en konkret vurdering. Selv om DSM og ODM i utgangspunktet var selvstendige juridiske personer, hadde de flere fellestrekk: Selskapene drev samme type aktivitet, administrative oppgaver var lagt til samme selskap - Odfjell Offshore AS, de hadde felles styre, samme ansatterepresentanter, felles verneombudsapparat, felles fagorganisering og var undergitt samme tariffområde. Ansatte beholdt også konsernansienniteten sin ved overføring mellom selskapene. Som et ytterligere moment var det en del av konsernets "policy" at de ansatte ble forflyttet mellom de ulike installasjonene, og dermed også selskapene. På denne bakgrunn konkluderte lagmannsretten med at virksomhetens art og hensynet til de $\varnothing v$ vige ansatte tilsa et "utvidet arbeidsgiverbegrep", og at overføringen dermed lå innenfor arbeidsgivers styringsrett.

\section{g) Sammenfatning}

I dette avsnittet er det først og fremst eventuelle hovedlinjer mellom avgjørelsene som står i fokus. Avgjørelsene er derfor sammenfattet etter slike hovedlinjer, og ikke kronologisk.

I Rieber-saken ${ }^{100}$ la lagmannsretten til grunn at selskapene innen Rieber-konsernet måtte anses som samme virksomhet med hensyn til stillingsvernet. Innad i konsernet var det fast praksis at arbeidstakerne ble flyttet dit det var behov for dem, selv om dette innebar en endring av de formelle ansettelsesavtalene. Det samme synspunktet ble lagt til grunn i Deep Sea Management-saken, ${ }^{101}$ hvor retten fant at to "sideordnede" selskaper innen Odfjell-konsernet måtte anses som samme virksomhet etter arbeidsmiljøloven. Det var fast praksis at arbeidstakerne kunne forflyttes mellom de to selskapene. Det var for øvrig også en sterk forbindelse mellom selskapene med hensyn til administrasjon og organisasjon, og selskapene drev med de samme aktivitetene. 
I Lincoln Electric-avgjørelsen ${ }^{102}$ la tingretten til grunn at det var en så sterk forbindelse mellom det datterselskapet arbeidstakerne var ansatt i og morselskapet, at selskapene ble ansett for å være samme virksomhet. Ved siden av at morselskapet eide hele datterselskapet, så var morselskapet også datterselskapets hovedkunde. For retten fremsto det som om datterselskapet reelt sett var styrt av morselskapet, og selskapene ble ansett for å være samme virksomhet i relasjon til oppsigelsene. Lignende betraktninger ble også lagt til grunn i Sveits-avgjørelsen, ${ }^{103}$ hvor lagmannsretten konkluderte med at morselskapet og datterselskapet $\mathrm{i}$ et konsern måtte anses som samme virksomhet. Etter rettens oppfatning var datterselskapet helt avhengig av morselskapet. Det ble også lagt vekt på at morselskapet tidligere hadde tilbudt arbeidstakeren arbeid i morselskapets tjeneste.

Lagmannsretten konkluderte i Translatør-saken ${ }^{104}$ med at et personlig advokatfirma og et aksjeselskap var å anse som samme virksomhet. Begge foretakene var eid av samme person. Det ble lagt avgjørende vekt på at selskapene fremstod som en enhet, både innad og utad. I tillegg spilte arbeidstakeren saken gjaldt en sentral rolle i begge selskapene. Lagmannsretten la en tilsvarende vurdering til grunn i Telepost-avgjørelsen. ${ }^{105} \mathrm{Et}$ morselskap og to datterselskaper ble vurdert som samme virksomhet basert på at arbeidstakeren hadde utført en vesentlig del av arbeidet sitt hos de ulike selskapene, og ikke bare der hvor han var ansatt. I tillegg ble ikke de formelle skillelinjene mellom selskapene fulgt opp i praksis.

Avgjørelsene som er behandlet i dette avsnittet har ett fellestrekk i at de reelle forholdene ga grunnlag for å fravike det som formelt var avtalt. På bakgrunn av ulike tilnærminger kom retten til at de formelle selskapsstrukturene ikke kunne tillegges vekt $\mathrm{i}$ arbeidsrettslig sammenheng, og selskapene ble dermed identifisert med hverandre etter arbeidsmiljøloven; de ble ansett for å utgjøre samme virksomhet.

Det fremgår ikke like tydelig av alle avgjørelsene at det dreier seg om sammensatte arbeidsgiverforhold. I enkelte av avgjørelsene viste retten til et "utvidet arbeidsgiver-

\footnotetext{
102 RG 1998 s. 1415 Lincoln Electric.

103 RG 2001 s. 1138 Sveits.

104 LG-1997-754 - LG-1997-789 - LG-1998-1021 Translatør.

105 LB-1998-2880 Telepost.
} 
begrep". ${ }^{106}$ Begrepet viser til at lovens arbeidsgiverbegrep gis anvendelse ut over det som følger av ordlyden; det tar sikte på å beskrive det at andre enn kontraktsmotparten i arbeidsavtalen anses som arbeidsgiver. I enkelte saker konkluderte retten kun med at flere rettssubjekter måtte anses som samme virksomhet. Under avsnitt 4.2 og punkt 4.63 har jeg nærmere beskrevet hvordan dette er å betrakte som sammensatte arbeidsgiverforhold.

\subsection{Arbeidsgiverforhold som ikke var sammensatt}

a) RG 2002 s. 1551 Oddst $\phi l$ (Frostating)

Saken gjaldt spørsmålet om et morselskap og et datterselskap hadde felles arbeidsgiveransvar i relasjon til oppsigelsesvernet. Morselskapet hadde skilt ut en del av virksomheten til et eget datterselskap. Enkelte arbeidstakere fulgte med, uten at nye arbeidsavtaler ble inngått. Da datterselskapet etter fire år gikk konkurs, ble arbeidstakerne sagt opp. De gikk til sak mot morselskapet og hevdet at også dette var arbeidsgiveren deres. På denne bakgrunn måtte oppsigelsene være ugyldige.

Lagmannsretten la til grunn at "et utvidet arbeidsgiveransvar" - arbeidsgiveransvar for morselskapet sammen med datterselskapet - forutsatte "særlige omstendigheter". Etter lagmannsrettens oppfatning var forholdet mellom morselskapet og datterselskapet som i regulære konsernforhold. Utskillelsen av datterselskapet var naturlig, og de formelle linjene ble fulgt. Forholdet mellom arbeidstakerne og morselskapet ga heller ikke grunnlag for felles ansvar mellom selskapene. Selv om overgangen til datterselskapet aldri var formalisert, ble arbeidstakerne ansett for å være tilstrekkelig klar over at de var ansatt i datterselskapet fra utskillelsestidspunktet. De hadde blant annet inngått tariffavtaler med datterselskapet som motpart. På denne bakgrunn kom lagmannsretten til at morselskapet ikke var arbeidsgiver for arbeidstakerne.

Arbeidstakerne hadde ved overgangen tilsynelatende akseptert ansettelse i datterselskapet. Den formelle arbeidsavtalen måtte dermed vike for de reelle forhold, basert på arbeidstakernes opptreden i etterkant. Tilsynelatende var inngåelsen av tariffavtale med datterselskapet et moment som ble tillagt avgjørende vekt. 


\section{b) Sammenfatning}

I Oddstøl-avgjørelsen vurderte lagmannsretten først "forretningsforholdet" mellom morselskapet og datterselskapet. Dette bar preg av å være et ordinært konsernforhold, samtidig som utskillelsen av datterselskapet hadde en naturlig forklaring. Med hensyn til "sekundærarbeidsforholdet" mellom morselskapet og arbeidstakerne la retten til grunn at det var tilstrekkelig klargjort overfor arbeidstakerne at de kun var ansatt i datterselskapet, til tross for at de ikke hadde inngått egne arbeidsavtaler med datterselskapet. I denne sammenheng ble det lagt vekt på at det var inngått en tariffavtale hvor datterselskapet var arbeidstakernes motpart.

Selv om det ikke var nedfelt i noen skriftlig arbeidsavtale, kom lagmannsretten til at arbeidstakerne var inneforstått med at arbeidsforholdet var overført fra morselskapet til datterselskapet. En kan se dette som at de reelle forhold ga grunnlag for å fravike det som formelt var avtalt.

\subsection{Hovedlinjer om sammensatte arbeidsgiverforhold og stillingsvernet}

\subsection{Overordnede betraktninger}

Som analysene under avsnittene 4.3 til 4.7 viser, har Høyesterett lagt til grunn at flere rettssubjekter kan være ansvarlige som arbeidsgivere for at arbeidsmiljølovens stillingsvernsregler blir overholdt; sammensatte arbeidsgiverforhold i relasjon til stillingsvernet. Disse arbeidsgiverforholdene er etablert på privatrettslig grunnlag, se nærmere om dette under punktene 2.41 og 2.43. Grunnlaget kan være enten avtale eller lov; de sammensatte arbeidsgiverforholdene kan anses som doble arbeidsavtaleforhold eller tilfeller av lovbasert delt arbeidsgiverposisjon. I denne presentasjonen av hovedlinjene er dette skillet lagt til grunn, selv om jeg også forsøker å redegjøre for enkelte gjennomgående linjer.

\subsection{Særlig om doble arbeidsavtaleforhold}

Sammensatte arbeidsgiverforhold kan etableres som doble arbeidsavtaleforhold på grunnlag av den hovedarbeidsavtalen som blir inngått mellom partene i "primærarbeidsforholdet"; arbeidstaker og primærarbeidsgiver. Dette synspunktet kom til uttrykk i både ExLog-saken ${ }^{107}$ og Stena Drilling-saken. ${ }^{108}$ I ExLog-saken la Høyesterett til grunn at arbeidstakerne hadde arbeidsforhold med både det utenlandske selskapet de hadde inngått 
hovedarbeidsavtale med, og med det norske selskapet hvor de var utplassert. Det fulgte uttrykkelig av hovedarbeidsavtalen at man tok sikte på at arbeidstakerne skulle ha arbeidsforhold med sine vertsforetak. I Stena Drilling-saken ble tilsvarende synspunkt lagt til grunn av Høyesterett uten noen videre drøftelse.

Spørsmålet ble dermed hvilke rettigheter og plikter som gjaldt i arbeidsforholdet med det norske selskapet; i "sekundærarbeidsforholdet". Til tross for at det var til dels avgjørende forskjeller mellom saksforholdene i ExLog-saken og Stena Drilling-saken på dette punkt, er det mulig å trekke linjer mellom den rettsoppfatningen Høyesterett ga uttrykk for i de to avgjørelsene.

I ExLog-saken la Høyesterett til grunn at både arbeidstaker, primærarbeidsgiver (ELU) og sekundærarbeidsgiver (ELN) måtte forholde seg til det som var avtalt i hovedarbeidsavtalen. Sekundærarbeidsgiveren var dermed bundet av hovedarbeidsavtalens bestemmelser uten å være part i denne. I hovedarbeidsavtalen var det avtalt flytteplikt for arbeidstakerne. Retten vurderte om enten en særskilt avtale mellom arbeidstaker og sekundærarbeidsgiver, eller sekundærarbeidsgiverens ut øvelse av arbeidsgiverfunksjoner, kunne gi grunnlag for å fravike flytteplikten. Det forelå ingen særskilt avtale mellom arbeidstakerne og sekundærarbeidsgiveren. Sekundærarbeidsgiver hadde ut $\varnothing v e t$ enkelte arbeidsgiverfunksjoner, og var dermed arbeidsgiver «i mange relasjoner» (s. 238). Dette var likevel ikke til hinder for at flytteplikten kunne gjøres gjeldende. Arbeidstakerne var dermed bundet av flytteplikten som fulgte av bestemmelsen i hovedarbeidsavtalen. Endelig måtte retten ta stilling til om arbeidsmiljøloven var til hinder for at flytteplikten ble gjort gjeldende. På bakgrunn av tidligere rettspraksis og behovet for å kunne avtale flytteplikt i internasjonale arbeidsforhold, kom retten til at gjennomføringen av den avtalte flytteplikten ikke ville innebære noen oppsigelse etter arbeidsmiljøloven.

I Stena Drilling-saken ble det som nevnt også lagt til grunn at arbeidstakerne hadde arbeidsforhold til to selskaper etter sine hovedarbeidsavtaler. De var utplassert av primærarbeidsgiveren (SDPL) til en sekundærarbeidsgiver (SD) gjennom secondmentavtaler, som inngikk som del i arbeidstakernes hovedarbeidsavtaler. Arbeidsforholdene mellom sekundærarbeidsgiveren og arbeidstakerne var dermed regulert av hovedarbeidsavtalene. Sekundærarbeidsgiveren hadde imidlertid utøvet alle arbeidsgiverfunksjonene over flere år. Arbeidstakernes tilknytning til primærarbeidsgiveren var av rent formell karakter. Høyesterett konkluderte på denne bakgrunn med at forbindelsen mellom arbeidstakerne og sekundærarbeidsgiver hadde karakter av å være et «ordinært ansettelsesforhold» (avsnitt 103), og at arbeidstakerne hadde de samme rettigheter som fast ansatte hos sekundærarbeidsgiveren. Sekundærarbeidsgiveren var dermed å anse som arbeidsgiver i 
relasjon til stillingsvernet, se nærmere om dette under punkt 4.43. Arbeidstakerne hadde således i utgangspunktet rett til å få overført arbeidsforholdene til det nye bemanningsselskapet, i likhet med fast ansatte hos sekundærarbeidsgiveren.

Arbeidstakerne hadde imidlertid flytteplikt etter hovedarbeidsavtalene, og i forbindelse med virksomhetsoverdragelsen ble de tilbakekalt etter denne. Men tilbakekallingsadgangen var begrenset ved tariffavtale som forutsatte at det forelå «good reason» (avsnitt 106). Ettersom gjennomføringen av flytteplikten etter Høyesteretts oppfatning ikke innebar en oppsigelse etter arbeidsmiljøloven, var aml. § 16-4 ikke til hinder for å gjøre flytteplikten gjeldende. Likevel konkluderte retten med at tilbakekallingen ikke var bindende for arbeidstakerne. På bakgrunn av samsvaret mellom saklighetskravet i tariffavtalen og arbeidsmiljølovens saklighetskrav ved oppsigelse, fant retten at aml. § 16-4 måtte gis analogisk anvendelse på tilbakekallingen.

Gjennomgangen viser at hovedarbeidsavtalen er det primære rettsgrunnlaget i doble arbeidsavtaleforhold. De rettigheter og plikter som følger av avtalens bestemmelser binder både arbeidstaker, primærarbeidsgiver og sekundærarbeidsgiver. I ExLog-saken fant ikke Høyesterett grunn til å fravike bestemmelsen om flytteplikt, som kunne gjøres gjeldende selv om det innebar at arbeidsforholdet med sekundærarbeidsgiveren opphørte.

Høyesterett har imidlertid gjennom nevnte rettspraksis signalisert at det kan gjøres unntak; hovedarbeidsavtalens bestemmelser kan fravikes.

For det første kan slik fravikelse tenkes på bakgrunn av saerskilt avtale mellom partene i "sekundærarbeidsforholdet"; arbeidstaker og sekundærarbeidsgiveren. I ExLog-saken vurderte Høyesterett et «offer of employment» fra sekundærarbeidsgiver (ELN) i denne sammenheng. Retten fant imidlertid at dette tilbudet ikke var ment for partene i "sekundærarbeidsforholdet", men for norske myndigheter. Arbeidstakerne kunne dermed ikke utlede rettigheter overfor sekundærarbeidsgiver på bakgrunn av dette tilbudet. I Stena Drilling-saken forelå ingen slik særskilt avtale.

For det andre kan hovedarbeidsavtalen fravikes på bakgrunn av sekundærarbeidsgivers utøvelse av arbeidsgiverfunksjoner. I ExLog-saken ble det lagt til grunn at sekundærarbeidsgiver (ELN) utøvde enkelte arbeidsgiverfunksjoner, og dermed var å anse som arbeidsgiver i enkelte relasjoner. Dette ledet likevel ikke til en fravikelse av hovedarbeidsavtalens bestemmelser. I Stena Drilling-saken utøvde sekundærarbeidsgiveren (SD) alle arbeidsgiverfunksjoner, og ble på denne bakgrunn ansett for å være arbeidsgiver i relasjon til stillingsvernet. Etter mitt syn innebar imidlertid ikke dette en fravikelse, men et supplement til hovedarbeidsavtalens bestemmelser om "sekundærarbeidsforholdet". 
Hovedarbeidsavtalen inneholdt ingen regulering av sekundærarbeidsgiverens ansvar for stillingsvernet.

Selv om Høyesterett har åpnet for at hovedarbeidsavtalen kan fravikes på bakgrunn av disse forholdene, foreligger det dermed ikke rettspraksis som tilsier at dette er blitt gjort.

I Stena Drilling-saken fant Høyesterett imidlertid at analogislutninger fra loven ga grunnlag for å fravike bestemmelsene i hovedarbeidsavtalen, jf. gjennomgangen av dette under punkt 4.44. Tilsvarende kan også tenkes ved gjennomføringen av en avtalt flytteplikt i nasjonale arbeidsforhold. I ExLog-saken fremhevet Høyesterett at det måtte være adgang til å avtale flytteplikt $\mathrm{i}$ «internasjonalt pregede arbeidsforhold» (s. 231). ${ }^{109}$

\subsection{Særlig om lovbasert delte arbeidsgiverposisjoner}

Når flere rettssubjekter anses som arbeidsgivere i samme arbeidsforhold, og dette ikke følger av hovedarbeidsavtalen, foreligger det en lovbasert delt arbeidsgiverposisjon. Hovedarbeidsavtalen vil typisk angi et rettssubjekt som arbeidsgiver, men en utenforstående aktør - tredjemann - anses for å være arbeidsgiver etter arbeidsmiljøloven basert på øvrige omstendigheter.

I Wärtsilä-saken ${ }^{110}$ konkluderte Høyesterett med at et morselskap måtte anses som arbeidsgiver sammen med sitt datterselskap. Arbeidstakeren var ansatt i datterselskapet; det var primærarbeidsgiver. Etter en konkret vurdering av "forretningsforholdet" mellom morselskapet og datterselskapet og "sekundærarbeidsforholdet" mellom morselskapet og arbeidstakeren, konkluderte retten med at også morselskapet var arbeidsgiver etter arbeidsmiljøloven; det var sekundærarbeidsgiver. Følgelig forelå et sammensatt arbeidsgiverforhold $i$ form av en lovbasert delt arbeidsgiverposisjon. I "forretningsforholdet" ble det lagt avgjørende vekt på at morselskapet hadde en dominerende posisjon overfor datterselskapet; en sterkere styring med driften enn det som var normalt i konsernforhold. "Sekundærarbeidsforholdet" var preget av at det var avtalt rettigheter og plikter mellom arbeidstaker og sekundærarbeidsgiver i hovedarbeidsavtalen. Samtidig utøvde morselskapet enkelte arbeidsgiverfunksjoner ved at det opptrådte i lønnsforhandlinger, utøvde en viss instruksjonsmyndighet og representerte datterselskapet

109 Dette er nærmere behandlet under punkt 4.35.

Rt. 1990 s. 1126 Wärtsilä. 
ved ansettelsen av arbeidstakeren. Arbeidstakeren mottok også en oppsigelse fra morselskapet, selv om det senere kom en oppsigelse fra datterselskapet.

I Rt. 1993 s. 345 Matherson-Selig la Høyesterett til grunn at to selskaper måtte anses som "samme virksomhet" i relasjon til arbeidsmiljølovens stillingsvernsregler. Arbeidstakerne var ansatt i det ene selskapet (MSE); dette var primærarbeidsgiver. MSE eide en majoritetsandel i VE. Høyesteretts konklusjon innebar at VE indirekte var å anse som arbeidstakernes sekundærarbeidsgiver. Konsekvensen av denne betraktningen var at også VE ble ansvarlig for at arbeidsmiljølovens stillingsvernsregler ble overholdt.

Felles for de to ovennevnte avgjørelsene var at Høyesterett fravek de formelle forhold. Selv om det var på det rene at arbeidstakerne kun hadde én arbeidsgiver etter sine arbeidsavtaler, konkluderte Høyesterett med at flere var ansvarlige som arbeidsgivere for at stillingsvernsreglene ble overholdt. I Wärtsilä-saken var grunnlaget for å fravike de formelle forhold at de reelle forhold ikke samsvarte med det som formelt var avtalt; flere arbeidsgiverfunksjoner ble utøvet av morselskapet, samtidig som den tette forbindelsen mellom selskapene på arbeidsgiversiden ga grunnlag for identifikasjon etter arbeidsmiljøloven. ${ }^{111}$ I Matherson-Selig-saken var det den tette forbindelse mellom selskapene og det at de drev samme virksomhet, som ble tillagt avgjørende vekt. I PPDdommen, ${ }^{112}$ hvor Høyesterett (under dissens 4-1) konkluderte med at arbeidstakerne ikke hadde flere arbeidsgivere, la flertallet avgjørende vekt på at det kun var primærarbeidsgiveren som utøvde arbeidsgiverfunksjonene.

Ansvaret for overholdelsen av stillingsvernsreglene ble ikke plassert hos det ene foretaket, det ble delt mellom dem. I Wärtsilä-saken la Høyesterett uttrykkelig til grunn at arbeidsmiljøloven ikke var til hinder for et «felles arbeidsgiveransvar» mellom et morselskap og et datterselskap (s. 1132). Det samme ble resultatet i Matherson-Seligsaken, selv om det ikke følger direkte av rettens premisser. Rettsoppfatningen om felles arbeidsgiveransvar ble så knesatt i PPD-dommen (s. 631).

111 Jf. lagmannsrettens mindretall i LE-1987-663 som Høyesterett sluttet seg til; se Rt. 1990 s. 1126 Wärtsilä (s. 1132).

112 Rt. 1997 s. 623 PPD. 


\subsection{Nærmere om posisjonen som sekundærarbeidsgiver}

Selv om tredjepersoner gjennom rettspraksis har blitt ansett for å være sekundærarbeidsgivere, er ikke denne arbeidsgiverposisjonen nødvendigvis absolutt.

I ExLog-saken ${ }^{113}$ la Høyesterett til grunn at sekundærarbeidsgiveren (ELN) «iallfall i mange relasjoner må anses som arbeidsgiver» (s. 238). Retten anga imidlertid ikke hvilke relasjoner den her siktet til; rettens konklusjon i saken var tilsynelatende ikke avhengig av dette.

Høyesterett ga uttrykk for tilsvarende synspunkter i Wärtsilä-saken, ${ }^{114}$ hvor det ble lagt til grunn at sekundærarbeidsgiver (morselskapet) var arbeidsgiver «i den forbindelse som her er aktuell» (s. 1132). Som jeg har redegjort nærmere for under punkt 4.52 ble morselskapet ansett for å være sekundærarbeidsgiver i relasjon til stillingsvernet og utbetalingen av arbeidsvederlag. 


\section{Konklusjoner}

Underveis $\mathrm{i}$ fremstillingen har jeg presentert noen slutninger om sammensatte arbeidsgiverforhold. Dette gjelder både sammensatte arbeidsgiverforhold i relasjon til arbeidsgivers HMS-ansvar (avsnittene 3.5 til 3.7) og i relasjon til stillingsvernet (avsnitt 4.9). I dette kapittel 5 sammenfatter jeg denne todelte fremstillingen til noen hovedlinjer. Samtidig fors $\varnothing$ ker jeg å utlede andre hovedlinjer, ved å sammenholde slutningene om HMS-ansvar og stillingsvern med hverandre. Først sammenfatter jeg slutningene om hvordan sammensatte arbeidsgiverforhold etableres. Deretter oppsummerer jeg slutningene om hvilke konsekvenser slike trepartsrelasjoner har for partenes rettigheter og plikter.

I fremstillingen har jeg behandlet sammensatte arbeidsgiverforhold på offentligrettslig grunnlag under arbeidsgivers HMS-ansvar, og tilsvarende forhold på privatrettslig grunnlag under arbeidsgivers ansvar for stillingsvernet. I min konklusjon vil jeg fortsatt benytte meg av "relasjonsbetegnelsene" HMS-ansvar og ansvar for stillingsvernet.

Som hovedregel utgjør hovedarbeidsavtalen (HAA) mellom primærarbeidsgiver (P) og arbeidstaker (AT) grunnlaget for rettigheter og plikter mellom dem. Hovedarbeidsavtalens bestemmelser er også avgjørende for om det i utgangspunktet foreligger et tosidig arbeidsforhold eller et sammensatt arbeidsgiverforhold basert på avtale; et dobbelt arbeidsavtaleforhold. Slike sammensatte arbeidsgiverforhold er etablert på privatrettslig grunnlag. ${ }^{115}$ Som hovedregel beror det på en tolkning av hovedarbeidsavtalen å fastlegge det nærmere innholdet av doble arbeidsavtaleforhold.

I rettspraksis er det også eksempler på at arbeidsmiljøloven kan gi grunnlag for sammensatte arbeidsgiverforhold, uten at det følger av en hovedarbeidsavtale; jeg har kalt dette for lovbasert delte arbeidsgiverposisjoner. ${ }^{116}$ Det kan i denne sammenheng bemerkes at det i rettspraksis er lagt til grunn at arbeidsmiljøloven ikke er til hinder for flere arbeidsgivere i samme arbeidsforhold. ${ }^{117}$

Jf. gjennomgangen under punktene 2.41 og 2.43 .

116 Jf. gjennomgangen under avsnitt 2.4.

117 Dette ble uttrykkelig lagt til grunn i Rt. 1985 s. 941 OIS (s. 943) og fulgte forutsetningsvis av Høyesteretts konklusjon i Rt. 1990 s. 1126 Wärtsilä (s. 1132). 
Høyesterett har lagt til grunn at det må foretas en vurdering av de konkrete forhold når man skal avgjøre om tredjeperson er ansvarlig som sekundærarbeidsgiver etter arbeidsmiljøloven; om det foreligger en delt sammensatt arbeidsgiverposisjon. ${ }^{118}$ Dette gjelder både i relasjon til stillingsvernsreglene og HMS-ansvaret.

I Wärtsilä-saken ${ }^{119}$ ble det lagt til grunn at ansvar som sekundærarbeidsgiver måtte bero på en «samlet vurdering» av "forretningsforholdet" og "sekundærarbeidsforholdet" (s. 1132). En tilsvarende vurdering ble lagt til grunn i OIS-saken, ${ }^{120}$ Asbest-saken ${ }^{121}$ og PPDsaken. ${ }^{122}$ Det kan dermed trekkes en linje fra OIS-saken til PPD-saken med hensyn til selve vurderingen, selv om vurderingstemaene var avhengige av om arbeidsgiverposisjonen relaterte seg til HMS-ansvaret eller stillingsvernet.

I Matherson-Selig-saken ${ }^{123}$ la Høyesterett til grunn at hvis primærarbeidsgiver og tredjeperson var å anse som "samme virksomhet" etter arbeidsmiljøloven, var dette tilstrekkelig for et felles ansvar. I et slikt tilfelle var det ikke nødvendig å vurdere "sekundærarbeidsforholdet" nærmere. Vurderingen av om flere rettssubjekter er samme virksomhet etter arbeidsmiljøloven skiller seg dermed fra den ordinære vurderingen av om flere er ansvarlige som arbeidsgivere i relasjon til stillingsvernet.

Den konkrete vurderingen av om tredjeperson er ansvarlig som sekundærarbeidsgiver i relasjon til HMS-ansvaret, er dermed rettet mot to forhold; "sekundærarbeidsforholdet" og "forretningsforholdet". Vurderingstemaet i "sekundærarbeidsforholdet" er om tredjeperson har styringsretten over arbeidstakeren. ${ }^{124}$ Bakgrunnen for dette er at styringsrett er en forutsetning for å kunne sikre at arbeidsmiljøbestemmelsene overholdes, samtidig som styringsretten er en arbeidsgiverfunksjon som «følger med arbeidsgiverposisjonen», jf. Rt. 1985 s. 941 OIS (s. 943). Vurderingstemaet i "forretningsforholdet" er om primærarbeidsgiver eller tredjeperson er nærmest til å sørge for at arbeidsmiljøbestemmelsene over-

Det ble lagt til grunn i Rt. 1985 s. 941 OIS (s. 943) og Rt. 1990 s. 419 Asbest (s. 422).

Rt. 1990 s. 1126 Wärtsilä.

Rt. 1985 s. 941 OIS.

Rt. 1990 s. 419 Asbest.

Rt. 1997 s. 623 PPD.

Rt. 1993 s. 345 Matherson-Selig

Jf. avsnitt 3.5 for en nærmere gjennomgang av hvordan dette kan utledes av OIS-saken og Asbest-saken. 
holdes, sett i lys av forbindelsen mellom dem. ${ }^{125}$ Dersom tredjeperson er nærmest til å sørge for slik etterlevelse av arbeidsmiljøloven, taler dette til fordel for å anse vedkommende for å være ansvarlig som sekundærarbeidsgiver. Basert på disse betraktninger er målet med den konkrete vurderingen å avgjøre om andre enn primærarbeidsgiver reelt sett har bedre forutsetninger enn primærarbeidsgiveren til å sørge for at arbeidsmiljøbestemmelsene overholdes, og om det er grunnlag for å holde vedkommende ansvarlig som følge av tilknytningen til partene i primærarbeidsforholdet.

Vurderingen av hvem som er arbeidsgiver i relasjon til stillingsvernet retter seg også mot "forretningsforholdet" og "sekundærarbeidsforholdet". Vurderingstemaet i "forretningsforholdet" er om primærarbeidsgiver og tredjeperson er sterkere knyttet til hverandre enn det som er normalt; eksempelvis ved at den ene har en "dominerende stilling" over den andre. Dette kan gi grunnlag for å fravike de formelle strukturene. ${ }^{126}$ Vurderingstemaet for "sekundærarbeidsforholdet" er om tredjeperson utøver arbeidsgiverfunksjoner i et slikt omfang at vedkommende må anses som arbeidsgiver i relasjon til stillingsvernet. I Wärtsilä-saken la Høyesterett vekt på at tredjeperson hadde utøvet en viss instruksjonsrett, opptrådt i lønnsforhandlinger og representerte primærarbeidsgiver i forbindelse med ansettelse og oppsigelse. De samme arbeidsgiverfunksjonene ble fremhevet av Høyesterett i PPD-saken, men i den saken var det primærarbeidsgiveren som hadde utøvet de nevnte arbeidsgiverfunksjonene. Retten konkluderte derfor med at tredjeperson (kommunene) ikke kunne anses for å være arbeidsgiver.

Gjennomgangen viser at "forretningsforholdet" og "sekundærarbeidsforholdet" en sentral rolle ved vurderingen av om det er grunnlag for en lovbasert delt arbeidsgiverposisjon. Vurderingstemaene for det enkelte forholdet avhenger imidlertid av hvilken relasjon vurderingen gjelder. Forklaringen bak dette ligger etter all sannsynlighet i ulikhetene mellom de to relasjonene; de grunnleggende forskjellene mellom arbeidsgivers HMSansvar og arbeidsgivers ansvar for overholdelsen av stillingsvernsreglene. Forskjellene mellom de to relasjonene belyses best ved å sammenholde slutningene fra dem med hverandre.

Jf. avsnitt 3.5. Dette har sammenheng med at ansvaret plasseres hos enten arbeidsgivers "virksomhetsleder" eller arbeidsgiverforetaket, jf. aml. §§ 19-1 og 19-3.

126 Se eksempelvis lagmannsrettens mindretall i LE-1987-663 Wärtsilä, og behandlingen av denne avgjørelsen under avsnitt 4.5. 
Som beskrevet over fokuserte Høyesterett på styringsretten i "sekundcerarbeidsforholdet", for å ta stilling til om tredjeperson var ansvarlig som arbeidsgiver i relasjon til HMSansvaret. Bakgrunnen for dette ligger $\mathrm{i}$ at myndigheten til å instruere og kontrollere arbeidet er en forutsetning for å kunne ivareta de kravene som arbeidsmiljøloven stiller til arbeidsmiljøet. Arbeidsgiverfunksjoner av økonomisk og administrativ art ble ikke tillagt vekt, jf. avsnitt 3.5. Basert på Høyesteretts avgjørelser i Wärtsilä-saken og PPD-saken, kreves det imidlertid mer enn bare styringsrett for at tredjeperson kan holdes ansvarlig som arbeidsgiver i relasjon til stillingsvernet. I disse avgjørelsene fremhevet Høyesterett også ansettelsesmyndighet og opptreden i lønnsforhandlinger som sentrale arbeidsgiverfunksjoner. I denne sammenheng kan det trekkes linjer til Stena Drilling-saken, ${ }^{127}$ hvor Høyesterett la til grunn at sekundærarbeidsgiver (SD) hadde utøvet alle arbeidsgiverfunksjoner overfor arbeidstakerne (avsnitt 104). Selv om Stena Drilling-saken gjaldt et dobbelt arbeidsavtaleforhold, var spørsmålet for Høyesterett hvilke rettigheter arbeidstakerne hadde overfor sekundærarbeidsgiver i relasjon til stillingsvernet; nærmere bestemt rettigheter i forbindelse med virksomhetsoverdragelse etter aml. kap. 16.

Analysene av rettspraksis viser at kravet til forbindelsen mellom partene i "sekundærarbeidsforholdet" er strengere i relasjon til stillingsvernet enn i relasjon til HMSansvaret. Bakgrunnen for denne betraktningen er at ansvar som arbeidsgiver i relasjon til stillingsvernet potensielt er mye mer kostbart og ressurskrevende for arbeidsgiver, enn ansvar i relasjon til HMS-ansvaret. For arbeidsgiver kan det være stor forskjell mellom det å måtte ivareta arbeidstakernes stillingsvern, og det å skulle sørge for at de daglige aktivitetene følger arbeidsmiljølovens krav.

Som et hovedtrekk ved vurderingen av "sekundærarbeidsforholdet" vil jeg fremheve Høyesteretts vektlegging av hvem som utøver arbeidsgiverfunksjoner. De reelle forhold er her avgjørende. Dette synspunktet har særlig støtte i dissensen i PPD-dommen, ${ }^{128}$ hvor flertallet la avgjørende vekt på at PPD-senteret utøvde arbeidsgiverfunksjonene, mens mindretallet argumenterte for at dette måtte anses som en delegering av arbeidsgiverfunksjoner fra samarbeidskommunene som hadde etablert senteret. Uavhengig av de

128 Rt. 1997 s. 623 PPD. 
bakenforliggende forhold ble her selve utøvelsen av arbeidsgiverfunksjoner tillagt vesentlig vekt. $^{129}$

Gjennomgangen av "sekundærarbeidsforholdet" demonstrerer hvordan Høyesterett har lagt til grunn en funksjonell tilncerming for å avgjøre om tredjeperson er å anse som arbeidsgiver. Utøvelsen av arbeidsgiverfunksjoner kan dermed gi grunnlag for å fravike de formelle strukturene $i$ arbeidsforholdene. På denne bakgrunn kan man si at arbeidsgiverbegrepet er sterkt forbundet med utøvelsen av arbeidsgiverfunksjoner. Dette er også lagt til grunn i arbeidsmiljølovens forarbeider. ${ }^{130}$

Ved vurderingen av "forretningsforholdet" i relasjon til HMS-ansvaret var vurderingstemaet om primærarbeidsgiver eller tredjeperson etter forholdet mellom dem hadde best forutsetninger til å sikre at arbeidsmiljøbestemmelsene ble overholdt. I relasjon til stillingsvernet var derimot vurderingstemaet om det var grunn til å opprettholde de formelle skillelinjene mellom primærarbeidsgiver og tredjeperson. Denne ulikheten har sin bakgrunn i at HMS-ansvaret plasseres, ${ }^{131}$ mens ansvaret for overholdelsen av stillingsvernsbestemmelsene $\mathrm{i}$ større grad fordeles. ${ }^{132}$ Fordelingen av ansvar i relasjon til stillingsvernet kan også betraktes som identifikasjon eller gjennomskjæring etter arbeidsmiljøloven, ved at flere rettssubjekter holdes ansvarlige for forpliktelser som i utgangspunktet tilhører primærarbeidsgiver. Dette kan ha sider mot selskapsrettens gjennomskjærings- og identifikasjonsregler, og et sideblikk til disse reglene er derfor inntatt under kapittel 6.

Oppsummeringsvis kan det sies om lovbasert delte arbeidsgiverposisjoner at det avhenger av en samlet vurdering av de konkrete forhold for å fastslå om et slikt sammensatt arbeidsgiverforhold er etablert. Vurderingen består av to hovedelementer; en vurdering av den selskaps- og kontraktsrettslige forbindelsen mellom partene i "forretningsforholdet", og en funksjonell tilnærming til forbindelsen mellom partene i "sekundærarbeidsforholdet".

Se nærmere om dette under punkt 4.74.

$130 \quad$ Jf. Ot.prp. nr. 49 (2004-2005) s. 76.

${ }^{131}$ | I både OIS-saken og Asbest-saken kom dette til uttrykk ved at Høyesterett først tok stilling til om tredjeperson var å anse som arbeidsgiver, og deretter plasserte ansvaret innenfor dennes organisasjon, enten hos virksomhetsleder eller hos foretaket som sådan, se nærmere gjennomgang under avsnittene 3.5 til 3.7.

132 Høyesterett la uttrykkelig til grunn i Wärtsilä-saken at primærarbeidsgiver og sekundærarbeidsgiver kunne ha delt ansvar i relasjon til stillingsvernet (s. 1132). 
Arbeidsgivers plikter i relasjon til arbeidsmiljøbestemmelsene er på mange måter vesensforskjellige fra pliktene i relasjon til arbeidstakers stillingsvern. Disse forskjellene gjenspeiles ved etableringen av lovbasert delte arbeidsgiverposisjoner i de ulike relasjonene. En tredjeperson kan oppfylle forutsetningene for å være arbeidsgiver i en relasjon, uten at det er tilfelle i en annen. Dette har også blitt uttrykkelig lagt til grunn i rettspraksis, jf. omtalen av dette under avsnitt 3.5 og punkt 4.94. Spørsmålet om tredjeperson er arbeidsgiver er dermed avhengig av de konkrete omstendigheter, og av hvilken relasjon posisjonen som sekundærarbeidsgiver relaterer seg til. På denne bakgrunn anser jeg posisjonen som sekundærarbeidsgiver for å være relativ; dette kan omtales som det relative sekundorarbeidsgiverbegrepet. ${ }^{133}$

Som nevnt innledningsvis vil etableringen av doble arbeidsavtaleforhold følge av hovedarbeidsavtalen. "Sekundærarbeidsforholdet" vil da som utgangspunkt være regulert av hovedarbeidsavtalen, på lik linje med "primærarbeidsforholdet". På bakgrunn av at trepartsforholdet bygger på avtale mellom partene, har "forretningsforholdet" en begrenset betydning. Dette betyr imidlertid ikke at doble arbeidsavtaleforhold er upåvirket av de faktiske omstendigheter eller av preseptorisk lovgivning. Både i ExLog-saken ${ }^{134}$ og i Stena Drilling-saken $^{135}$ vurderte Høyesterett hvilke arbeidsgiverfunksjoner sekundærarbeidsgiver utøvde, for å fastslå i hvilke relasjoner det forelå et "sekundærarbeidsforhold". I Stena Drilling-saken påpekte Høyesterett at sekundærarbeidsgiveren (SD) utøvde alle arbeidsgiverfunksjonene, og at SD dermed var arbeidsgiver i relasjon til stillingsvernet. ${ }^{136} \mathrm{I}$ rettpraksis er det også åpnet for at en særskilt avtale mellom partene i "sekundærarbeidsforholdet" kan få betydning for hvordan det doble arbeidsavtaleforholdet skal vurderes. Preseptorisk lovgivning kan også føre til at det som er bestemt i hovedarbeidsavtalen blir fraveket. Høyesterett konkluderte i Stena Drilling-saken med at analogislutninger fra arbeidsmiljøloven hindret primærarbeidsgiver $\mathrm{i}$ å tilbakekalle de

133 I juridisk teori er fenomenet omtalt som det relative arbeidsgiverbegrep, jf. Storeng m.fl. (2011) s. 69. Begrepet er uheldig, ettersom det kan gi inntrykk av at posisjonen som arbeidsgiver generelt sett er relativ. Posisjonen som primærarbeidsgiver er imidlertid absolutt; primærarbeidsgiver blir ikke fri sitt ansvar selv om andre anses for å være arbeidsgiver.

134 Rt. 1989 s. 231 ExLog.

135 Rt. 2012 s. 983 Stena Drilling.

136 I avgjørelsen ble dette formulert som at arbeidstakerne hadde en «ansettelsesmessig tilknytning» til SD (avsnitt 105). 
seconderte arbeidstakerne, til tross for at en slik kompetanse fulgte av hovedarbeidsavtalen. $^{137}$

De rettslige konsekvensene for partene av at et sammensatt arbeidsgiverforhold foreligger, avhenger av om det relaterer seg til HMS-ansvaret eller stillingsvernet. I relasjon til HMSansvaret innebærer det at en sekundærarbeidsgiver er ansvarlig for at arbeidsmiljøbestemmelsene overholdes, sammen med primærarbeidsgiver. Dette innebærer imidlertid ikke et solidaransvar, men flere potensielle ansvarssubjekter. HMS-ansvaret er et offentligrettslig ansvar som innebærer offentligrettslige sanksjoner, jf. aml. §§ 19-1 og 19-3. På bakgrunn av legalitetsprinsippet i norsk rett må ansvarsplasseringen ha hjemmel i lov.

Virksomhetslederansvaret etter $\S 19-1$ forutsetter at vedkommende «leder virksomheten» til den som er ansvarlig som arbeidsgiver etter loven. ${ }^{138}$ Foretaksansvaret forutsetter kun at lovens bestemmelser er overtrådt av en som handler «på vegne av» foretaket etter strl. § 48a, jf. aml. § 19-3. Foretaksansvaret favner derfor videre enn kun for de som er ansatt i foretaket, noe som ble illustrert i Krankjennelsen. ${ }^{139}$ Temaet er nærmere behandlet under avsnitt 3.7. Konsekvensene av at et arbeidsgiverforhold er sammensatt i relasjon til stillingsvernet, er at arbeidstakerne har rettigheter overfor andre enn primærarbeidsgiver i tilknytning til opphør av arbeidsforholdet. Wärtsilä-dommen og PPD-dommen er prejudikater for et slikt "felles ansvar" mellom primærarbeidsgiver og sekundærarbeidsgiver. ${ }^{140}$

137 Se behandlingen av dette under punkt 4.92.

138 Problemstillingene knyttet til dette er nærmere behandlet under avsnitt 3.6.

139 Rt. 1982 s. 645 Krankjennelsen.

$140 \quad$ Dette behandles utførlig under avsnitt 4.9. 


\section{Sideblikk til selskapsrettens gjennomskjærings- og identifikasjonsregler}

Som nevnt under kapittel 5 reiser sammensatte arbeidsgiverforhold særlige problemstillinger knyttet til gjennomskjæring og identifikasjon. I all hovedsak gjelder dette lovbasert delte arbeidsgiverposisjoner på privatrettslig grunnlag, ettersom primærarbeidsgiver og sekundærarbeidsgiver kan idømmes et «felles arbeidsgiveransvar» for at arbeidsmiljølovens bestemmelser om stillingsvern blir overholdt. ${ }^{141}$

Andenæs skiller mellom to former for gjennomskjæring av selskapsformen; å identifisere et selskap med en aksjonær, og gjennomskjæring av ansvarsbegrensningen. ${ }^{142}$ Jeg velger å omtale formene som henholdsvis identifikasjon og ansvarsgjennombrudd.

Wärtsilä-saken ${ }^{143}$ er et godt eksempel på at identifikasjon kan forekomme i sammensatte arbeidsgiverforhold. Spørsmålet var her om et morselskap var ansvarlig for overholdelsen av stillingsvernsreglene sammen med datterselskapet. I premissene sluttet førstvoterende seg til «de synspunkter lagmannsrettens mindretall har gitt uttrykk for» (s. 1132). Etter lagmannsrettens oppfatning gjaldt saken «identifikasjon i relasjon til arbeidsmiljøloven». ${ }^{144}$ Også Rt. 1993 s. 345 Matherson-Selig kan vurderes som et tilfelle av identifikasjon mellom to selskaper. I den konkrete saken la Høyesterett til grunn at to selskaper kunne anses som samme virksomhet etter arbeidsmiljøloven, og følgelig holdes ansvarlige for at bestemmelsene om stillingsvern ble overholdt. Det er også flere eksempler i rettspraksis fra underordnede domstoler på slik identifikasjon, jf. gjennomgangen av avgjørelsene under avsnitt 4.8 .

Lincoln Electric-saken ${ }^{145}$ og Sveits-saken ${ }^{146}$ kan imidlertid anses som eksempler på sammensatte arbeidsgiverforhold grunnet ansvarsgjennombrudd.

Jf. Rt. 1990 s. 1126 Wärtsilä (s. 1132), rettsoppfatningen ble senere knesatt av Høyesterett i Rt. 1997 s. 623 PPD (s. 631).

142 Jf. Andenæs, Aksjeselskaper og allmennaksjeselskaper (2006) s. 38 flg.

143 Rt. 1990 s. 1126 Wärtsilä.

144 Jf. LE-1987-663.

145 RG 1998 s. 1415 Lincoln Electric

146 RG 2001 s. 1138 Sveits. 
I denne sammenheng kan det være naturlig å knytte noen bemerkninger til avgjørelsen i Rt. 1937 s. 21 Ulrikka, som i arbeidsmiljølovens forarbeider er tatt til inntekt for et «delt arbeidsgiveransvar». 147

Saken gjaldt krav om ekstrahyre. Et kondemnert skip ble solgt til utlandet, og mannskapet ble avskjediget. Rederiet som i utgangspunktet eide skipet hadde pantsatt det til en bank, og det var banken som stod for salget. Spørsmålet var om sjøfolkene kunne gjøre sine krav gjeldende direkte overfor banken. Høyesterett kom til at banken måtte hefte sammen med rederiet. Førstvoterende viste i denne sammenheng til byrettens begrunnelse og overrettens flertall. Byrettens flertall la til grunn at rederiet var overstyrt av banken. Om det rettslige grunnlaget for kravet ble det så lagt til grunn at:

«Efter sjølovens $§ 273$ blir eieren personlig ansvarlig for sjøfordringer, når skibet frivillig selges til utlandet. Direkte har denne bestemmelse ikke anvendelse på skibets panthaver. Men således som forholdet var i dette tilfelle, hvor panthaveren faktisk hadde hånd og hals over skibets drift og avgjørelsen ved skibets salg og kjøpesummens innbetaling, antar retten at bestemmelsen må få analogisk anvendelse på panthaveren således at denne blir solidarisk ansvarlig med rederiet» (s. 25).

Overrettens flertall la til grunn at banken var en kreditor med kontroll over skipet, ettersom den hadde innkassert kjøpesummen, måtte den innfri fordringene som var sikret ved sjøpant med det mottatte beløpet.

I den konkrete saken var det ingen direkte forbindelse mellom panthaver og arbeidstakerne. Selv om banken fremtvang utskiftning av disponent og kaptein, og bestemte disponentens lønn, utøvde banken ingen arbeidsgiverfunksjoner overfor sjøfolkene. Banken kunne heller ikke anses som "samme virksomhet" som rederiet. Alt tyder på at Høyesterett ga sin tilslutning til et rent selskapsrettslig ansvarsgjennombrudd. ${ }^{148}$

Som gjennomgangen over viser, så kan sammensatte arbeidsgiverforhold anses som trekantforhold etter gjennomskjærings- og identifikasjonsreglene. Dette er imidlertid et temafelt for seg, som ligger utenfor denne fremstillingens rammer. Konsernutvalget, se NOU 1996: 6 s. 34. Nylig er den lagt til grunn av Skipsarbeidslovutvalget NOU-2012-18 Rett om bord s. 101, jf. note 14 i kapittel 7. Aarbakke m.fl. (2004) s. 39. I sistnevnte argumenteres det imidlertid for Høyesterett her ga sin tilslutning til «alminnelige rettslige synspunkter og ikke spesifikke aksjerettslige regler». 


\section{Avsluttende bemerkninger}

Analysen av rettspraksis om sammensatte arbeidsgiverforhold viser at denne typen trepartsrelasjoner kan oppstå i flere ulike situasjoner. I mange arbeidsforhold vil det være aktuelt at arbeidstakerne har direkte forbindelse med andre aktører, enn den som er angitt som motpart i ansettelseskontrakten. Konsekvensene av dette kan være inngripende for de involverte aktørene. Dette gjelder særlig for en tredjeperson som etter omstendighetene kan bli ansvarlig som arbeidsgiver.

Arbeidslivet er i konstant endring. Økt globalisering og nye organiseringsmodeller for bedrifter er med på å påvirke både arbeidstakeres og arbeidsgiveres hverdag. I dag kan man enkelt opprette et firma utenlands, for så å opprette en norsk filial (for eksempel et registrert NUF) som står for hoveddelen av foretakets virksomhet. Samtidig oppstår ulike selskapsgrupperinger på tvers av landegrensene. Næringslivet må i større grad enn tidligere tilpasse seg et globalt marked, og en global konkurransesituasjon. Som en konsekvens av dette kan det være avgjørende for et foretak å organisere arbeidskraften på en mest mulig effektiv og kostnadsbesparende måte.

I denne sammenheng er det viktig med et arbeidsrettslig regelverk som tillater at bedriftene tilpasser seg, men samtidig sørger for at arbeidstakernes interesser ivaretas. I rettspraksis om sammensatte arbeidsgiverforhold har domstolene fors $\varnothing \mathrm{kt}$ å forholde seg til disse til tider motstridende interessene. Enkelte ganger stemmer de formelle forhold ikke overens med virkeligheten. Ifølge rettspraksis kan det som formelt er blitt avtalt bli fraveket på bakgrunn av de reelle forhold. På denne måten kan eksempelvis arbeidsgiveransvar plasseres hos den som i realiteten opptrer som arbeidsgiver overfor arbeidstakerne.

Vurderingen av om et arbeidsgiverforhold er sammensatt, og hvor arbeidsgiveransvaret i så fall skal plasseres, er en oppgave som i stor grad er overlatt til domstolene. Rettspraksis utgjør dermed en sentral rettskilde når problemstillinger som oppstår i denne sammenheng skal avgjøres. Imidlertid vil ofte problemstillinger knyttet til sammensatte arbeidsgiverforhold være for konkrete til at Høyesterett ser grunn til å behandle dem, og de blir dermed endelig avgjort $\mathrm{i}$ de underordnede rettsinstansene. Slike avgjørelser har begrenset prejudikatsverdi. For å unngå at utfallet av rettsanvendelsen virker tilfeldig, er det nødvendig med et mer helhetlig perspektiv enn den enkeltstående rettsavgjørelse. Juridisk teori kan i denne sammenheng spille en sentral rolle, ved at det kan trekkes linjer mellom konkrete avgjørelser. Slik kan man kartlegge hvordan problemstillinger knyttet til sammensatte arbeidsgiverforhold best løses ut fra et overordnet perspektiv. 


\section{Litteraturliste}

\section{Litteratur}

Aarbakke m.fl. (2004) Magnus Aarbakke, Asle Aarbakke, Gudmund Knudsen, Tone Ofstad, Jan Skåre, Aksjeloven og allmennaksjeloven Kommentarutgave, 2. utg., Oslo: Universitetsforlaget, 2004.

Andenæs (1997) Mads Henry Andenæs, Rettskildelære, Oslo: M.H. Andenæs, 1997.

Andenæs (2006) Mads Henry Andenæs, Aksjeselskaper og allmennaksjeselskaper, Oslo: M.H. Andenæs, 2006.

Eckhoff m.fl. (2001) Torstein Eckhoff og Jan E. Helgesen, Rettskildelære, 5. utg., Oslo: Universitetsforlaget, 2001.

Evju (1974)

Stein Evju, «Arbeidervernloven $§ 5$ og en høyesterettskjennelse», Lov og rett, 1974, s. 116-129.

Evju (2003)

Stein Evju, «Arbeidsrett og styringsrett - et perspektiv», Arbeidsrett og arbeidsliv, Bind 1, 2003, s. 3-32.

Evju (2012)

Stein Evju, «Virksomhetsoverdragelse, arbeidsavtalebegrep og common law - Rt. 2012 s. 983», Nytt i privatretten 2012, Nr. 3, 2012, s. 1-4.

Fanebust (1989) Arne Fanebust, Oppsigelse i arbeidsforhold, 2. utg., Oslo: Universitetsforlaget, 1989.

Fleischer (1998) Carl August Fleischer, Rettskilder og juridisk metode, Oslo: Ad Notam Gyldendal, 1998.

Hagstrøm (2011) Viggo Hagstrøm, Obligasjonsrett, 2. utg., Oslo:

Universitetsforlaget, 2011.

Jakhelln (2004) Henning Jakhelln, «Arbeidstakeres rettigheter mot morselskap», MarIus, Nr. 310, 2004, s. 75-96.

Reiersen m.fl. Hedvig Bugge Reiersen og Beate Sjåfjell, «NUF-kaoset i norsk rett - et bidrag til oppklaring», Tidsskrift for rettsvitenskap, 2010, s. 423-462.

Storeng m.fl. (2011) Nils H. Storeng, Tom H. Beck, Arve Due Lund, Arbeidslivets spilleregler, 2. utg., Oslo: Universitetsforlaget, 2011. 
Lover

1902

Almindelig borgerlig Straffelov 22. mai 1902 nr. 10 (strl.)

1976

Lov 4. juni 1976 nr. 59 om aksjeselskaper.

1977

Lov 4. februar 1977 nr. 4 om arbeidervern og arbeidsmiljø m.v. (arbeidsmiljøloven av 1977 eller aml. (1977))

1997

Lov 13. juni 1997 nr. 44 om aksjeselskaper (asl.).

2005

Lov 17. juni 2005 nr 62 om arbeidsmiljø, arbeidstid og stillingsvern mv. (arbeidsmiljøloven)

Offentlige publikasjoner

NOU 1995:17 Om organisering av kommunal og fylkeskommunal virksomhet.

NOU 1996: 6 Arbeidstakeres stilling i konsernforhold m.v.

NOU 1999: 34

Nytt millennium - nytt arbeidsliv?

NOU 2004: 5

Arbeidslivslovutvalget - Et arbeidsliv for trygghet, inkludering og vekst. (arbeidsmiljøloven)

NOU 2012: $18 \quad$ Rett om bord - Ny skipsarbeidserslov.

Ot.prp. nr. 3 (1975-76) Om lov om arbeidervern og arbeidsmiljø m.v (arbeidsmiljøloven av 1977)

Ot.prp. nr. 49 (2004-2005) Om lov om arbeidsmiljø, arbeidstid og stillingsvern mv. (arbeidsmiljøloven)

Innst. O. nr. 100 (2004-2005) Innstilling fra kommunalkomiteen om lov om arbeidsmiljø, arbeidstid og stillingsvern mv. (arbeidsmiljøloven)

Forh. O. nr. 52 (2004-2005) Arbeidsmiljøloven - 6. juni 2005

Høringsbrev 98/5481 M1 BOS Oppfølgning av Konsernutvalgets innstilling m v Kommunal- og regionaldepartementet. 27.08.1998

\section{Annet}

Arbeidsrettens internettsider (arbeidsretten.no),

http://www.arbeidsretten.no/index.php?module=Pagesetter $\&$ func=viewpub\&tid=4\&pid=4, november 2012. 


\section{Rettsavgjфrelser}

Høyesterettsavgjørelser

Rt. 1972 s. 1311 Pollo

Rt. 1981 s. 899

Rt. 1982 s. 645 Krankjennelsen

Rt. 1982 s. 878

Rt. 1983 s. 196

Rt. 1984 s. 773 Flesland

Rt. 1985 s. 185 Kraftverk

Rt. 1985 s. 941 OIS

Rt. 1985 s. 1319 ExLog-kjennelsen (Høyesteretts kjæremålsutvalg).

Rt. 1987 s. 1412 Bowlin I (Høyesteretts kjæremålsutvalg).

Rt. 1988 s. 476. Bowlin II (Høyesteretts kjæremålsutvalg).

Rt. 1988 s. 654

Rt. 1988 s. 692

NAD 1988 s. 696. Ancock (Høyesteretts kjæremålsutvalg).

Rt. 1989 s. 231 ExLog

Rt. 1990 s. 419 Asbest

Rt. 1990 s. 1126 Wärtsilä

Rt. 1993 s. 345 Matherson-Selig (Høyesteretts kjæremålsutvalg)

Rt. 1993 s. 490 Reksten

Rt. 1993 s. 954 Back Stage

Rt. 1997 s. 623 PPD

HR-1998-561-K (Høyesteretts kjæremålsutvalg)

HR-2004-372-U (Høyesteretts kjæremålsutvalg)

Rt. 2012 s. 983 Stena Drilling

Arbeidsrettens avgjørelser

ARD 1980 s. 79

ARD 1981 s. 49 
Praksis fra underordnede domstoler

LE-1987-663

TSNES-1988-73

Sarpsborg byretts kjennelse 19. oktober 1992 (92-00947 A)

LE-1992-228

RG 1996 s. 463Rieber (Gulating)

LG-1997-754 - LG-1997-789 - LG-1998-1021 Translatør

RG 1998 s. 1415 Lincoln Electric (Tønsberg)

LB-1998-2880 Telepost

RG 2001 s. 1138 Sveits (Borgarting)

RG 2002 s. 1551 Oddstøl (Frostating)

RG 2004 s. 255 Adressa (Frostating)

RG 2007 s. 756 Deep Sea Management (Gulating)

EU-domstolens praksis

Sak C-242/09 Albron Albron Catering BV v FNV Bondgenoten, John Roest, [2010] EUD I-10309 